\title{
Synthesis of the Bridged [5-7-7] Tricyclic Core of Eurifoloid A
}

\author{
Bao-Long $\mathrm{Hou}^{\dagger}$, Li-Xuan $\mathrm{Li}^{\dagger}$ and Chuang-Chuang $\mathrm{Li}^{*}{ }^{\dagger}$ \\ †Shenzhen Key Laboratory of Small Molecule Drug Discovery and Synthesis, Shenzhen Grubbs \\ Institute and Department of Chemistry, Southern University of Science and Technology, Shenzhen \\ 518055, China. \\ *Corresponding author. E-mail: ccli@sustech.edu.cn.
}

\section{Supporting Information}

\section{Table of Contents}

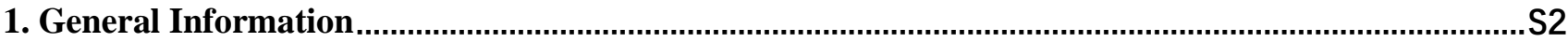

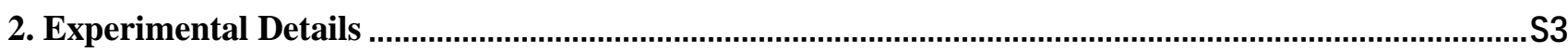

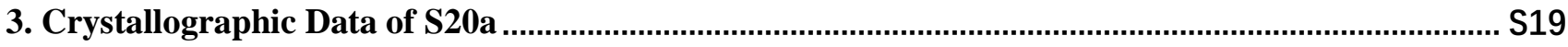

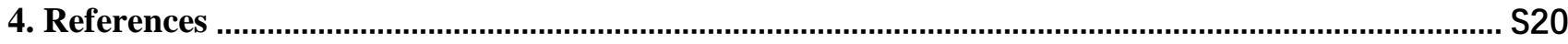

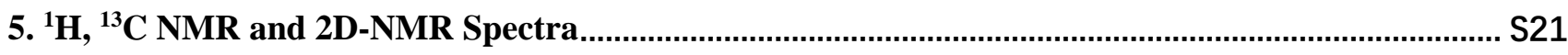




\section{General Information}

All air and water sensitive reactions were carried out under argon atmosphere with dry solvents under anhydrous conditions, unless otherwise noted. All the chemicals were purchased commercially and used without further purification. Dry dichloromethane (DCM) and acetonitrile $\left(\mathrm{CH}_{3} \mathrm{CN}\right)$ were distilled from calcium hydride. Dry diethyl ether $\left(\mathrm{Et}_{2} \mathrm{O}\right)$, tetrahydrofuran (THF), and toluene $(\mathrm{PhMe})$ were distilled from sodium-benzophenone. Other solvents purification was conducted according to Purification of Laboratory Chemicals (Perrin, D. D.; Armarego, W. L. and Perrins, D. R., Pergamon Press: Oxford, 1980). Yields refered to chromatographically, unless otherwise stated. Lower temperatures were maintained using acetone/ $\mathrm{CO}_{2}(\mathrm{~s})\left(-78{ }^{\circ} \mathrm{C}\right)$, salt/ice baths $\left(-20^{\circ} \mathrm{C}\right)$ and water/ice baths $\left(0{ }^{\circ} \mathrm{C}\right)$. Reactions were monitored by thin-layer chromatography (TLC) carried out on $0.25 \mathrm{~mm}$ Tsingdao silica gel plates (60F-254) that were analyzed by fluorescence upon $254 \mathrm{~nm}$ irradiation or staining with basic aqueous potassium permanganate $\left(\mathrm{KMnO}_{4}\right)$ or an ethanolic solution of phosphomolybdic acid, and heat as developing agents. If not specially mentioned, flash column chromatography used silica gel (200-300 mesh) supplied by Tsingtao Haiyang Chemicals (China). Preparative thin layer chromatography (PTLC) separations were carried out $0.50 \mathrm{~mm}$ Yantai (China) silica gel plates.

IR spectra were recorded on a Shimadzu IR Prestige 21 using thin films of the sample on $\mathrm{KBr}$ plates and only major peaks are reported in $\mathrm{cm}^{-1}$. All products were further characterized by high resolution mass spectra (HRMS). The X-ray intensity data were measured on a Bruker APEX-II CCD diffractometer with Mo Ka radiation. NMR spectra were recorded on either a Brüker Avance $400\left({ }^{1} \mathrm{H}: 400 \mathrm{MHz},{ }^{13} \mathrm{C}: 100 \mathrm{MHz}\right)$, or Brüker Avance $500\left({ }^{1} \mathrm{H}: 500\right.$ $\left.\mathrm{MHz},{ }^{13} \mathrm{C}: 125 \mathrm{MHz}\right)$, and calibrated using residual undeuterated solvent as an internal reference $\left(\mathrm{CDCl}_{3}, \delta 7.26 \mathrm{ppm}\right.$ ${ }^{1} \mathrm{H}$ NMR, $\delta 77.16 \mathrm{ppm}{ }^{13} \mathrm{C}$ NMR), ( $\mathrm{CD}_{3} \mathrm{OD}, \delta 4.87 \mathrm{ppm}{ }^{1} \mathrm{H} \mathrm{NMR}, \delta 49.00 \mathrm{ppm}{ }^{13} \mathrm{C}$ NMR). The following abbreviations were used to explain the multiplicities: $\mathrm{s}=$ singlet, $\mathrm{d}=$ doublet, $\mathrm{t}=$ triplet, $\mathrm{q}=$ quartet, $\mathrm{m}=$ multiplet. 


\section{Experimental Details}

\section{Synthesis of compound 13}

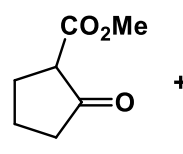

8

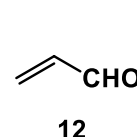

12
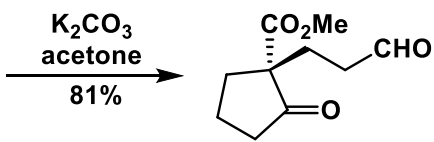

13

To a solution of $\beta$-keto ester $8(22.0 \mathrm{~g}, 155 \mathrm{mmol}, 1.0$ equiv. $)$ in acetone $(600 \mathrm{~mL}, 0.26 \mathrm{M})$ was added $\mathrm{K}_{2} \mathrm{CO}_{3}(25.7$ g, 186 mmol, 1.2 equiv.), followed by acrolein $\left(12,10.4 \mathrm{~g}, 186 \mathrm{mmol}, 1.2\right.$ equiv.). The mixture was stirred at $25{ }^{\circ} \mathrm{C}$ for $30 \mathrm{~min}$. The solution was filtered through a celite pad and concentrated under reduced pressure. The residue was purified by flash-column chromatography on silica gel (hexanes/Et $2 \mathrm{O}, 1: 1 \sim 3: 4)$ to provide 13 (24.9 g, $81 \%$ ) as a colorless oil.

$\boldsymbol{R}_{\boldsymbol{f}}=0.3$ (hexane: $\mathrm{EtOAc}=5: 1$ );

IR (film) $\lambda \max 2958,1722,1442,1234,1159 \mathrm{~cm}^{-1}$;

${ }^{1} \mathbf{H}$ NMR $\left(500 \mathrm{MHz}, \mathrm{CDCl}_{3}\right) \delta 9.72(\mathrm{t}, J=1.2 \mathrm{~Hz}, 1 \mathrm{H}), 3.68(\mathrm{~s}, 3 \mathrm{H}), 2.70-2.61(\mathrm{~m}, 1 \mathrm{H}), 2.52-2.37(\mathrm{~m}, 3 \mathrm{H}), 2.32$ $-2.24(\mathrm{~m}, 1 \mathrm{H}), 2.18-2.11(\mathrm{~m}, 1 \mathrm{H}), 2.03-1.81(\mathrm{~m}, 4 \mathrm{H}) \mathrm{ppm}$;

${ }^{13} \mathbf{C}$ NMR $\left(125 \mathrm{MHz}, \mathrm{CDCl}_{3}\right) \delta 214.6,201.1,171.7,59.0,52.7,39.6,38.0,34.1,25.6,19.6$ ppm;

HRMS (ESI) $\mathrm{C}_{10} \mathrm{H}_{15} \mathrm{O}_{4}[\mathrm{M}+\mathrm{H}]^{+}:$199.0965, found: 199.0967.

\section{Synthesis of compound 14}

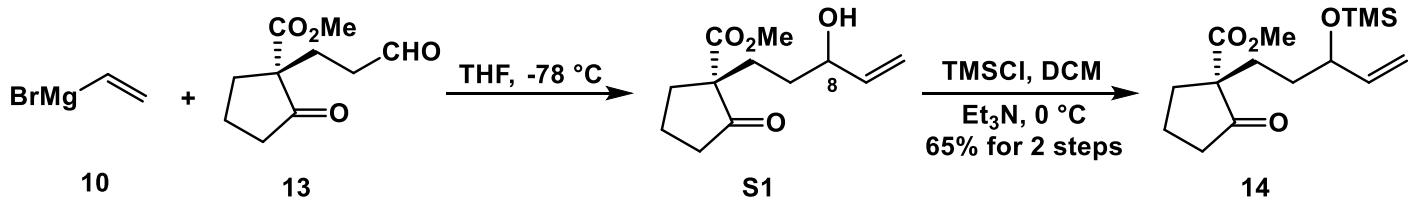

To a stirred solution of 13 (13.0 g, $65.65 \mathrm{mmol}, 1.0$ equiv.) in THF (250 mL, 0.26 M) was added dropwise vinylmagnesium bromide $\left(\mathbf{1 0}, 1.0 \mathrm{M}\right.$ in THF, $72.2 \mathrm{~mL}, 72.2 \mathrm{mmol}, 1.1$ equiv.) at $-78^{\circ} \mathrm{C}$ and the reaction mixture was stirred at $-78^{\circ} \mathrm{C}$ for $1.0 \mathrm{~h}$. Following quenching with saturated aqueous $\mathrm{NH}_{4} \mathrm{Cl}(100 \mathrm{~mL})$, the reaction mixture was extracted EtOAc $(3 \times 100 \mathrm{~mL})$. The organic layer filtrated through a pad of celite by the aid of EtOAc and organic layers were dried over $\mathrm{MgSO}_{4}$, filtered, and concentrated under reduced pressure to give S1, which was used for the next step without further purification.

TMSCl (14.26 g, 131.3mmol, 2.0 equiv.) was added to alcohol S1 and $\mathrm{Et}_{3} \mathrm{~N}$ (19.9 g, 196.95 mmol, 3.0 equiv.) in $\operatorname{DCM}(250 \mathrm{~mL}, 0.26 \mathrm{M})$ at $0{ }^{\circ} \mathrm{C}$. After $14 \mathrm{~h}$ of stirring at $25^{\circ} \mathrm{C}$, the reaction was quenched with saturated aqueous $\mathrm{NaHCO}_{3}(100 \mathrm{~mL})$, and the resulting mixture was extracted with EtOAc $(3 \times 100 \mathrm{~mL})$. The combined organic extracts were washed with brine and dried over anhydrous $\mathrm{Na}_{2} \mathrm{SO}_{4}$. Filtration and evaporation in vacuo furnished the crude 
product. The residue was purified by flash-column chromatography on silica gel (hexanes/EtOAc, 20:1 10:1) to provide TMS ether 14 (12.7 $\mathrm{g}, 65 \%$ for 2 steps) as a yellow oil.

$\boldsymbol{R}_{\boldsymbol{f}}=0.3$ (hexane: $\mathrm{EtOAc}=19: 1$ );

IR (film) $\lambda \max 2956,1726,1251,840 \mathrm{~cm}^{-1}$;

${ }^{1} \mathbf{H}$ NMR $\left(500 \mathrm{MHz}, \mathrm{CDCl}_{3}\right) \delta 5.85-5.67(\mathrm{~m}, 1 \mathrm{H}), 5.22-4.94(\mathrm{~m}, 2 \mathrm{H}), 4.14-3.97(\mathrm{~m}, 1 \mathrm{H}), 3.69(\mathrm{~s}, 3 \mathrm{H}), 2.53-$ $2.47(\mathrm{~m}, 1 \mathrm{H}), 2.44-2.36(\mathrm{~m}, 1 \mathrm{H}), 2.29-2.20(\mathrm{~m}, 1 \mathrm{H}), 2.02-1.84(\mathrm{~m}, 4 \mathrm{H}), 1.57-1.47(\mathrm{~m}, 2 \mathrm{H}), 1.41-1.33(\mathrm{~m}$, 1H), 0.09 (s, 9H) ppm;

${ }^{13}$ C NMR $\left(125 \mathrm{MHz}, \mathrm{CDCl}_{3}\right) \delta 215.0,171.7,141.0,140.9,114.6,73.8,60.3,52.7,38.2,33.01,32.96,29.8,19.7$, 0.3 ppm;

HRMS (ESI) $\mathrm{C}_{15} \mathrm{H}_{25} \mathrm{O}_{4} \mathrm{Si}[\mathrm{M}-\mathrm{H}]^{+}: 297.1525$, found: 297.1527.

Note: Treatment of aldehyde $\mathbf{1 3}$ with vinylmagnesium bromide led to the formation $\mathbf{S 1}$ as a pair of inseparable diastereomers (d.r. $=1: 1$ at $\mathrm{C} 8$ ). Because the $\mathrm{C} 8$ configurations would be eliminated by oxidation of the alcohol to ketone in the target molecule, both diastereomers could be useful for the following synthesis.

\section{Synthesis of compound 15}

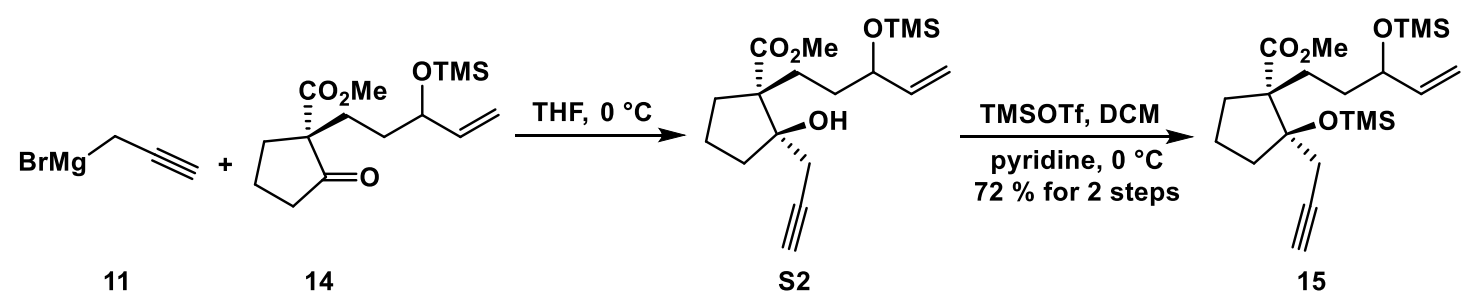

To a stirred solution of compound $14(4.5 \mathrm{~g}, 15.1 \mathrm{mmol}, 1.0$ equiv.) in THF (40 mL, $0.38 \mathrm{M})$ was added dropwise propargylmagnesium bromide ${ }^{1} \mathbf{1 1}$ (2.0 equiv.) at $0^{\circ} \mathrm{C}$ and the reaction mixture was stirred at $0{ }^{\circ} \mathrm{C}$ for $3 \mathrm{~h}$. Following quenching with saturated aqueous $\mathrm{NH}_{4} \mathrm{Cl}(10 \mathrm{~mL})$, the reaction mixture was extracted by EtOAc $(3 \times 50 \mathrm{~mL})$, dried over $\mathrm{MgSO}_{4}$, and evaporated under reduced pressure to give oil $\mathbf{S 2}$, which was used for the next step without further purification.

TMSOTf (6.7 g, $30.2 \mathrm{mmol}, 2.0$ equiv.) was added to $\mathbf{S} 2$ and pyridine ( $3.6 \mathrm{~g}, 45.3 \mathrm{mmol}, 3.0$ equiv.) in DCM (70 $\mathrm{mL}, 0.22 \mathrm{M})$ at $0{ }^{\circ} \mathrm{C}$. After $10 \mathrm{~h}$ of stirring at $0{ }^{\circ} \mathrm{C}$, the reaction was quenched with saturated aqueous $\mathrm{NaHCO}_{3}(50$ $\mathrm{mL})$, and the resulting mixture was extracted with DCM $(3 \times 50 \mathrm{~mL})$. The combined organic extracts were washed with brine $(50 \mathrm{~mL})$ and dried over anhydrous $\mathrm{Na}_{2} \mathrm{SO}_{4}$. The dried solution was filtered and concentrated. The residue obtained was purified by flash-column chromatography on silica gel (hexanes/EtOAc, 20:1 10:1) give TMS ether 15 (4.45 g, $72 \%$ for 2 steps) as a yellow oil.

$\boldsymbol{R}_{\boldsymbol{f}}=0.6$ (hexane: $\mathrm{EtOAc}=10: 1$ );

IR (film) $\lambda \max 2956,1728,1438,1253,1080,865 \mathrm{~cm}^{-1}$;

${ }^{1} \mathbf{H}$ NMR $\left(500 \mathrm{MHz}, \mathrm{CDCl}_{3}\right) \delta 6.01-5.62(\mathrm{~m}, 2 \mathrm{H}), 5.16-5.01(\mathrm{~m}, 4 \mathrm{H}), 4.02(\mathrm{q}, J=6.3 \mathrm{~Hz}, 2 \mathrm{H}), 3.67-3.52(\mathrm{~m}$, $6 \mathrm{H}), 2.47-2.34(\mathrm{~m}, 4 \mathrm{H}), 2.23-2.14(\mathrm{~m}, 2 \mathrm{H}), 2.05-1.99(\mathrm{~m}, 4 \mathrm{H}), 1.92-1.84(\mathrm{~m}, 2 \mathrm{H}), 1.76-1.56(\mathrm{~m}, 8 \mathrm{H}), 1.43-$ $1.16(\mathrm{~m}, 6 \mathrm{H}), 0.28-0.13(\mathrm{~m}, 18 \mathrm{H}), 0.12-0.04(\mathrm{~m}, 18 \mathrm{H}) \mathrm{ppm}$; 
${ }^{13} \mathrm{C} \mathrm{NMR}\left(125 \mathrm{MHz}, \mathrm{CDCl}_{3}\right) \delta 176.1,176.0,141.6,141.3,114.2,113.8,85.9,85.8,81.9,74.5,74.4,71.0,61.9,61.8$, 51.8, 51.7, 36.92, 36.90, 34.2, 34.0, 31.7, 31.6, 29.3, 28.9, 28.22, 28.19, 19.78, 19.75, 2.42, 2.40, 0.44, 0.40 ppm; HRMS (ESI) $\mathrm{C}_{21} \mathrm{H}_{39} \mathrm{O}_{4} \mathrm{Si}_{2}[\mathrm{M}+\mathrm{H}]^{+}: 411.2377$, found: 411.2381 .

\section{Synthesis of compound 16}
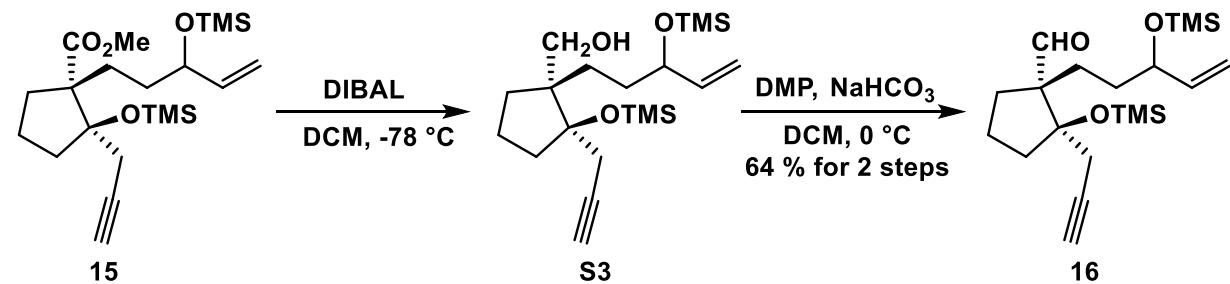

The compound 15 (3.6 g, $8.78 \mathrm{mmol}, 1.0$ equiv.) was dissolved in DCM (44 mL, $0.2 \mathrm{M})$ at $-78{ }^{\circ} \mathrm{C}$. Diisobutylaluminum hydride (1.5 M in toluene, $12.9 \mathrm{~mL}, 19.3 \mathrm{mmol}, 2.2$ equiv.) was added dropwise and the solution was stirred at $-78{ }^{\circ} \mathrm{C}$ for $1.5 \mathrm{~h}$. The reaction was quenched with EtOAc and saturated aqueous potassium tartrate tetrahydrate $(40 \mathrm{~mL})$. Stirring was continued until the solution was clear and extracted with DCM $(3 \times 60 \mathrm{~mL})$. The combined extracts were dried by $\mathrm{Na}_{2} \mathrm{SO}_{4}$, filtered, concentrated, and evaporation in vacuum furnished the crude product $\mathbf{S 3}$ as a yellow oil, which was used for the next step without further purification.

To a solution of compound $\mathbf{S 3}$ in DCM $(40 \mathrm{~mL}, 0.2 \mathrm{M})$ was added $\mathrm{NaHCO}_{3}(3.7 \mathrm{~g}, 43.9 \mathrm{mmol}, 5.0$ equiv.) and Dess-Martin reagent (7.4 g, $17.56 \mathrm{mmol}, 2.0$ equiv.) in small portions at $0{ }^{\circ} \mathrm{C}$. The resulting mixture was stirred at the same temperature for $3.0 \mathrm{~h}$. The reaction was then quenched with saturated aqueous solution $\mathrm{Na}_{2} \mathrm{~S}_{2} \mathrm{O}_{3}(20 \mathrm{~mL})$ and $\mathrm{NaHCO}_{3}(20 \mathrm{~mL})$, and extracted with DCM $(3 \times 60 \mathrm{~mL})$. The combined organic layers were dried over $\mathrm{Na}_{2} \mathrm{SO}_{4}$, and solvents were removed under vacuum. The obtained residue was purified by flash-chromatography on silica gel (hexane/EtOAc, 30:1) to give $\mathbf{1 6}$ (2.14 g, $64 \%$ for 2 steps) as a yellow oil.

$\boldsymbol{R}_{f}=0.44$ (hexane: EtOAc $=29: 1$ );

IR (film) $\lambda \max 2954,1726,1249,1112,840,754 \mathrm{~cm}^{-1}$;

${ }^{1} \mathbf{H}$ NMR $\left(500 \mathrm{MHz}, \mathrm{CDCl}_{3}\right) \delta 9.68(\mathrm{~d}, J=1.9 \mathrm{~Hz}, 2 \mathrm{H}), 5.82-5.71(\mathrm{~m}, 2 \mathrm{H}), 5.14(\mathrm{~d}, J=17.1 \mathrm{~Hz}, 2 \mathrm{H}), 5.03(\mathrm{dd}, J$ $=10.3,5.2 \mathrm{~Hz}, 2 \mathrm{H}), 4.03(\mathrm{~d}, J=5.7 \mathrm{~Hz}, 2 \mathrm{H}), 2.50(\mathrm{dd}, J=17.2,2.7 \mathrm{~Hz}, 2 \mathrm{H}), 2.39(\mathrm{dt}, J=17.2,2.3 \mathrm{~Hz}, 2 \mathrm{H}), 2.14-$ $1.97(\mathrm{~m}, 6 \mathrm{H}), 1.88-1.78(\mathrm{~m}, 4 \mathrm{H}), 1.72-1.64(\mathrm{~m}, 4 \mathrm{H}), 1.60-1.50(\mathrm{~m}, 4 \mathrm{H}), 1.35-1.27(\mathrm{~m}, 4 \mathrm{H}), 0.21-0.14(\mathrm{~m}$, $18 \mathrm{H}), 0.13-0.07(\mathrm{~m}, 18 \mathrm{H}) \mathrm{ppm}$;

${ }^{13}$ CNMR $\left(125 \mathrm{MHz}, \mathrm{CDCl}_{3}\right) \delta 206.2,206.1,141.4,141.3,114.2,114.0,85.54,85.46,81.11,81.09,74.3,74.2,72.4$, $65.1,65.0,37.5,37.4,33.3,33.2,27.9,27.84,27.83,27.8,26.5,26.51,26.47,19.6,19.5,2.36,2.35,0.5,0.4$ ppm; HRMS (ESI) $\mathrm{C}_{20} \mathrm{H}_{36} \mathrm{O}_{3} \mathrm{NaSi}_{2}[\mathrm{M}+\mathrm{Na}]^{+}: 403.2112$, found: 403.2117 .

\section{Synthesis of compound 17}




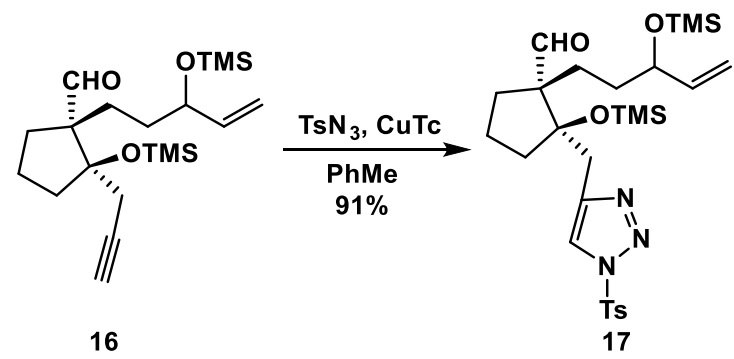

To a solution of compound 16 (3.8 g, $10 \mathrm{mmol}, 1.0$ equiv.) in dry PhMe (100 mL, $0.1 \mathrm{M})$ was added copper(I) thiophene-2-carboxylate (191 mg, $1 \mathrm{mmol}, 0.1$ equiv.), followed by addition of tosyl azide ( $\mathrm{TsN}_{3}, 2.2 \mathrm{~g}, 11 \mathrm{mmol}$, 1.1 equiv.) in a dropwise manner at $25^{\circ} \mathrm{C}$. The reaction mixture was then stirred at the same temperature for $6 \mathrm{~h}$. The residue was concentrated under vacuum, and the residue was purified by a flash column chromatography on silica gel (hexane/EtOAc, 5:1) to give $\mathbf{1 7}(5.3 \mathrm{~g}, 91 \%)$ as a colorless oil.

$\boldsymbol{R}_{f}=0.3$ (hexane: $\mathrm{EtOAc}=5: 1$ );

IR (film) $\lambda \max 2956,2360,1718,1595,1396,1249,1196,840,671,586 \mathrm{~cm}^{-1}$;

${ }^{1} \mathbf{H}$ NMR $\left(500 \mathrm{MHz}, \mathrm{CDCl}_{3}\right) \quad \delta 9.66(\mathrm{~s}, 1 \mathrm{H}), 9.63(\mathrm{~s}, 1 \mathrm{H}), 7.99(\mathrm{~d}, J=8.4 \mathrm{~Hz}, 4 \mathrm{H}), 7.90(\mathrm{~d}, J=2.8 \mathrm{~Hz}, 2 \mathrm{H}), 7.37$

$(\mathrm{d}, J=8.2 \mathrm{~Hz}, 4 \mathrm{H}), 5.76-5.65(\mathrm{~m}, 2 \mathrm{H}), 5.16-4.99(\mathrm{~m}, 4 \mathrm{H}), 4.08-3.93(\mathrm{~m}, 2 \mathrm{H}), 2.91(\mathrm{~d}, J=3.6 \mathrm{~Hz}, 1 \mathrm{H}), 2.88$

$(\mathrm{d}, J=3.4 \mathrm{~Hz}, 2 \mathrm{H}), 2.80(\mathrm{~d}, J=8.4 \mathrm{~Hz}, 2 \mathrm{H}), 2.76(\mathrm{~d}, J=8.3 \mathrm{~Hz}, 1 \mathrm{H}), 2.44(\mathrm{~s}, 6 \mathrm{H}), 2.09-2.05$ (m, 2H), $1.96-1.67$

(m, 10H), $1.62-1.45(\mathrm{~m}, 4 \mathrm{H}), 1.35-1.15(\mathrm{~m}, 4 \mathrm{H}), 0.10$ (s, 9H), 0.09 (s, 9H), -0.13 (s, 9H), -0.16 (s, 9H) ppm;

${ }^{13} \mathrm{C}$ NMR $\left(125 \mathrm{MHz}, \mathrm{CDCl}_{3}\right) \delta 206.3,206.2,147.3,143.9,141.2,141.0,133.33,133.31,130.5,128.8,122.9,122.8$,

$114.6,114.3,86.6,86.4,74.1,74.0,65.2,65.0,36.7,36.5,34.10,34.07,33.2,33.0,27.7,27.5,26.2,25.8,22.0,19.53$,

$19.51,2.2,2.1,0.45,0.43 \mathrm{ppm}$;

HRMS (ESI) $\mathrm{C}_{27} \mathrm{H}_{44} \mathrm{O}_{5} \mathrm{~N}_{3} \mathrm{SSi}_{2}[\mathrm{M}+\mathrm{H}]^{+}:$578.2535, found: 578.2535 .

\section{Synthesis of compound 21}

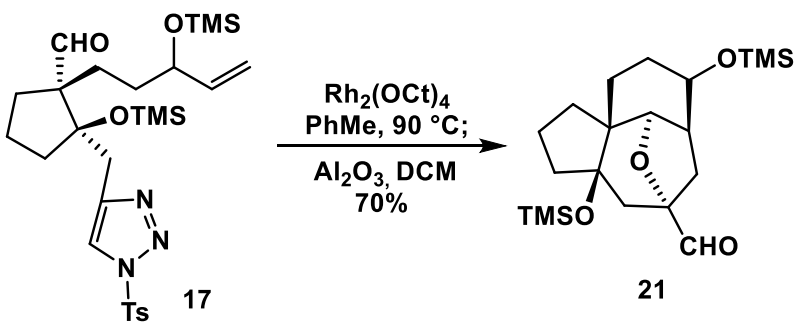

An oven-dried tube was charged with triazole 17 (1.16 g, 2 mmol, 1.0 equiv.), $3 \AA \mathrm{MS}$ (450 mg), and $\mathrm{Rh}_{2}(\mathrm{OCt})_{4}$ ( $31 \mathrm{mg}, 0.04 \mathrm{mmol}, 0.02$ equiv.). The tube was evacuated and backfilled with argon (repeated three times). Then, $\mathrm{PhMe}(20 \mathrm{ml}, 0.1 \mathrm{M})$ was added into the reaction via syringe. The reaction mixture was stirring at $90{ }^{\circ} \mathrm{C}$ for $8 \mathrm{~h}$. The solution was then allowed to cool to $25^{\circ} \mathrm{C}$, and DCM ( $40 \mathrm{ml}$ ) was added into the reaction, followed by basic alumina $(10 \mathrm{~g})$. The solution was stirred for $1.5 \mathrm{~h}$. The residue was concentrated in vacuum, purified by a flash-column chromatography on silica gel (hexane/EtOAc, 8:1 3:1) to afford 21 (553 $\mathrm{mg}, 70 \%$ ) as a colorless oil.

$\boldsymbol{R}_{f}=0.3$ (hexane: $\mathrm{EtOAc}=5: 1$ ); 
IR (film) $\lambda \max 2954,1735,1454,1355,1249,1087,1033,867 \mathrm{~cm}^{-1}$;

${ }^{1} \mathbf{H}$ NMR $\left(500 \mathrm{MHz}, \mathrm{CDCl}_{3}\right) \delta 9.60(\mathrm{~d}, J=1.4 \mathrm{~Hz}, 2 \mathrm{H}), 4.19(\mathrm{~d}, J=6.1 \mathrm{~Hz}, 1 \mathrm{H}), 3.95(\mathrm{q}, J=3.6 \mathrm{~Hz}, 1 \mathrm{H}), 3.98(\mathrm{~d}, J$ $=6.0 \mathrm{~Hz}, 1 \mathrm{H}), 3.93-3.87(\mathrm{~m}, 1 \mathrm{H}), 2.62-2.54(\mathrm{~m}, 1 \mathrm{H}), 2.45-2.41(\mathrm{~m}, 1 \mathrm{H}), 2.34-2.32(\mathrm{~m}, 1 \mathrm{H}), 2.18-2.13(\mathrm{~m}$, $2 \mathrm{H}), 2.09-2.06(\mathrm{~d}, J=14.1 \mathrm{~Hz}, 1 \mathrm{H}), 2.01-1.96(\mathrm{~m}, 4 \mathrm{H}), 1.89-1.84(\mathrm{~m}, 4 \mathrm{H}), 1.80-1.71(\mathrm{~d}, J=4.9 \mathrm{~Hz}, 1 \mathrm{H}), 1.74$ $-1.71(\mathrm{~m}, 1 \mathrm{H}), 1.61-1.51(\mathrm{~m}, 6 \mathrm{H}), 1.49-1.40(\mathrm{~m}, 5 \mathrm{H}), 1.34-1.25(\mathrm{~m}, 2 \mathrm{H}), 1.12-0.98(\mathrm{~m}, 1 \mathrm{H}), 0.15(\mathrm{~s}, 18 \mathrm{H})$, $0.09(\mathrm{~s}, 18 \mathrm{H}) \mathrm{ppm}$;

${ }^{13}$ C NMR $\left(125 \mathrm{MHz}, \mathrm{CDCl}_{3}\right) \delta 201.6,201.0,85.6,84.3,84.0,82.4,81.8,81.1,69.6,69.4,47.6,46.7,46.00,45.96$, 45.7, 45.2, 44.6, 44.2, 44.1, 43.0, 32.3, 31.8, 30.5, 29.8, 27.8, 27.2, 22.2, 21.7, 2.60, 2.55, 0.4, 0.3 ppm;

HRMS (ESI) $\mathrm{C}_{20} \mathrm{H}_{35} \mathrm{O}_{4} \mathrm{Si}_{2}[\mathrm{M}-\mathrm{H}]^{+}: 395.2080$, found: 395.2079 .

\section{Synthesis of compound S20a}

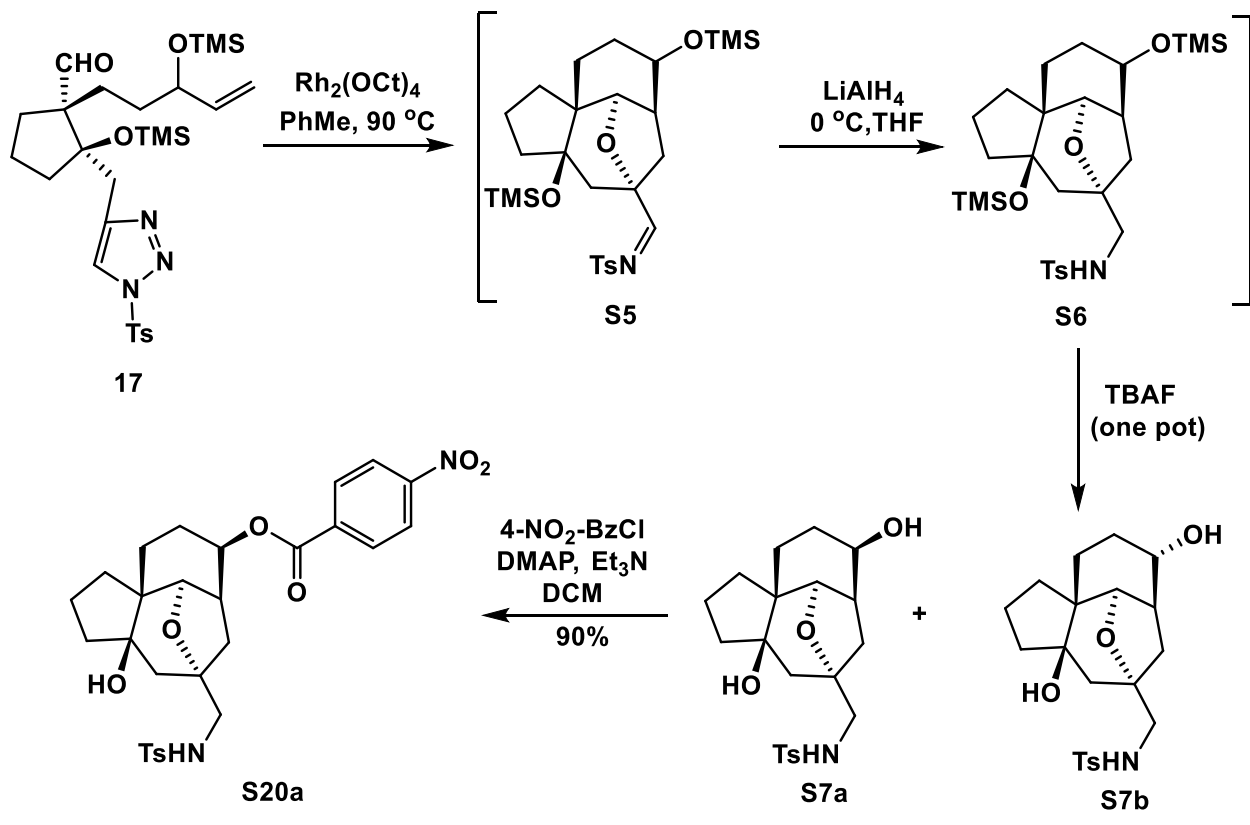

An oven-dried tube was charged with triazole 17 (90 mg, $0.156 \mathrm{mmol}, 1.0$ equiv.), $3 \AA \mathrm{MS}$ ( $35 \mathrm{mg})$, and $\mathrm{Rh}_{2}(\mathrm{OCt})_{4}$ ( $2.5 \mathrm{mg}, 0.0031 \mathrm{mmol}, 0.02$ equiv.). The tube was evacuated and backfilled with argon (repeated three times). Then toluene $(2.0 \mathrm{ml})$ was added into the reaction via syringe. The reaction mixture was stirring at $90{ }^{\circ} \mathrm{C}$ for $8 \mathrm{~h}$. The solution was then allowed to cool to $25^{\circ} \mathrm{C}$. THF $(4.0 \mathrm{ml})$ was added into the reaction via syringe. The solution was cool to $0{ }^{\circ} \mathrm{C}$. $\mathrm{LiAlH}_{4}\left(1 \mathrm{M}\right.$ in THF, $0.31 \mathrm{~mL}, 2.0$ equiv.) was added dropwise and the solution was stirred at $0{ }^{\circ} \mathrm{C}$ for $1.5 \mathrm{~h}$. Following was added dropwise TBAF ( $1 \mathrm{M}$ in THF, $0.31 \mathrm{~mL}, 2.0$ equiv. $)$ and the solution was stirred at $25^{\circ} \mathrm{C}$ for $0.5 \mathrm{~h}$ quenching with saturated aqueous $\mathrm{NH}_{4} \mathrm{Cl}(5 \mathrm{~mL})$, the reaction mixture was extracted by $\mathrm{DCM}(3 \times 5 \mathrm{~mL})$. The combined organic layers were washed with saturated brine $(5 \mathrm{~mL})$, dried over $\mathrm{Na}_{2} \mathrm{SO}_{4}$, concentrated in vacuum. The crude residue was purified by flash-chromatography on silica gel (hexane/EtOAc, 2:3) to afford S7a (21 mg, $33 \%$ ) as a white foam.

A solution of $\mathbf{S 7 a}\left(21 \mathrm{mg}, 0.05 \mathrm{mmol}, 1.0\right.$ equiv.) in anhydrous DCM $(5 \mathrm{~mL})$ was added $\mathrm{Et}_{3} \mathrm{~N}(0.021 \mathrm{~mL}, 0.15$ mmol, 3.0 equiv.) and DMAP ( $6 \mathrm{mg}, 0.05 \mathrm{mmol}, 1.0$ equiv.) at $0{ }^{\circ} \mathrm{C}$. After being stirred at the same temperature for 
5 minutes, 4-nitrobenzoyl chloride ( $19 \mathrm{mg}, 0.1 \mathrm{mmol}, 2.0$ equiv.) was added to the reaction. The mixture was warmed to $25^{\circ} \mathrm{C}$ and stirred for 30 minutes. The reaction was quenched by addition of saturated aqueous $\mathrm{NH}_{4} \mathrm{Cl}(5 \mathrm{~mL})$. Then the aqueous layer was extracted with DCM $(3 \times 5 \mathrm{~mL})$. The combined organic layers were washed with brine and dried over $\mathrm{Na}_{2} \mathrm{SO}_{4}$. The dried solution was filtered and concentrated. The residue obtained was purified by flashcolumn chromatography on silica gel (hexane/EtOAc, 3:1 1:2) to afford $\mathbf{S 2 0 a}(25 \mathrm{mg}, 90 \%)$ as a white solid suitable for X-ray analysis.

Note: The crude $\mathbf{S 7}$ a and $\mathbf{S 7 b}$ was purified carefully by column chromatography on silica gel (hexane/EtOAc, 2:3) to afford the desired compound S7a and the remaining inseparable mixture of S7a and S7b. The product S7a was characterized and was used in the next step.

\section{Date for S7a}

$\boldsymbol{R}_{\boldsymbol{f}}=0.20$ (hexane: $\mathrm{EtOAc}=1: 2$ );

${ }^{1}$ H NMR (500 MHz, CD 3 OD) $\delta 7.72(\mathrm{~d}, J=8.2 \mathrm{~Hz}, 2 \mathrm{H}), 7.36(\mathrm{~d}, J=8.2 \mathrm{~Hz}, 2 \mathrm{H}), 3.88-3.79(\mathrm{~m}, 1 \mathrm{H}), 3.77(\mathrm{~d}, J=$ $5.9 \mathrm{~Hz}, 1 \mathrm{H}), 3.31-3.29(\mathrm{~m}, 1 \mathrm{H}), 2.95-2.75(\mathrm{~m}, 2 \mathrm{H}), 2.59-2.46(\mathrm{~m}, 1 \mathrm{H}), 2.41(\mathrm{~s}, 3 \mathrm{H}), 2.09-1.95(\mathrm{~m}, 3 \mathrm{H}), 1.88$ (s, 1H), $1.75-1.63(\mathrm{~m}, 5 \mathrm{H}), 1.54-1.39(\mathrm{~m}, 4 \mathrm{H}), 1.06-0.98(\mathrm{~m}, 1 \mathrm{H})$;

${ }^{13} \mathrm{C}$ NMR $\left(126 \mathrm{MHz}, \mathrm{CD}_{3} \mathrm{OD}\right) \delta 143.2,137.7,129.3,126.7,84.4,80.0,78.0,68.6,50.3,47.8,46.3,46.0,43.9,43.8$, 31.1, 30.0, 26.4, 21.1, 20.0;

HRMS (ESI) $\mathrm{C}_{21} \mathrm{H}_{28} \mathrm{NO}_{4} \mathrm{~S}\left[\mathrm{M}+\mathrm{H}-\mathrm{H}_{2} \mathrm{O}\right]^{+}: 390.1739$, found: 390.1731 .

\section{Date for S20a}

$\boldsymbol{R}_{\boldsymbol{f}}=0.25$ (hexane: $\mathrm{EtOAc}=2: 1$ );

${ }^{1} \mathbf{H}$ NMR $\left(500 \mathrm{MHz}, \mathrm{CDCl}_{3}\right) \delta 8.28(\mathrm{~d}, J=8.9 \mathrm{~Hz}, 2 \mathrm{H}), 8.17(\mathrm{~d}, J=8.9 \mathrm{~Hz}, 2 \mathrm{H}), 7.71(\mathrm{~d}, J=8.3 \mathrm{~Hz}, 2 \mathrm{H}), 7.29(\mathrm{~d}, J$ $=8.1 \mathrm{~Hz}, 2 \mathrm{H}), 5.29(\mathrm{dt}, J=11.7,5.8 \mathrm{~Hz}, 1 \mathrm{H}), 4.77(\mathrm{dd}, J=8.2,4.6 \mathrm{~Hz}, 1 \mathrm{H}), 3.91(\mathrm{~d}, J=5.7 \mathrm{~Hz}, 1 \mathrm{H}), 3.07(\mathrm{dd}, J=$ $12.2,8.3 \mathrm{~Hz}, 1 \mathrm{H}), 2.90(\mathrm{dt}, J=12.3,6.0 \mathrm{~Hz}, 1 \mathrm{H}), 2.82-2.71(\mathrm{~m}, 1 \mathrm{H}), 2.40(\mathrm{~s}, 3 \mathrm{H}), 2.38-2.29(\mathrm{~m}, 1 \mathrm{H}), 2.27-2.20$ $(\mathrm{m}, 1 \mathrm{H}), 2.05-2.00(\mathrm{~m}, 1 \mathrm{H}), 1.97-1.91(\mathrm{~m}, 2 \mathrm{H}), 1.82-1.73(\mathrm{~m}, 4 \mathrm{H}), 1.63-1.57(\mathrm{~m}, 4 \mathrm{H}), 1.47-1.41(\mathrm{~m}, 1 \mathrm{H}), 1.22-$ $1.18(\mathrm{~m}, 1 \mathrm{H}) \mathrm{ppm}$;

${ }^{13} \mathbf{C}$ NMR $\left(126 \mathrm{MHz}, \mathrm{CDCl}_{3}\right) \delta 164.2,150.7,143.7,136.7,136.0,130.9,129.9,127.2,123.7,84.2,80.2,79.0,73.3$, 50.3, 48.6, 47.4, 44.1, 43.8, 43.6, 31.7, 30.0, 23.7, 21.8, $21.7 \mathrm{ppm}$.

\section{Synthesis of compound 22}

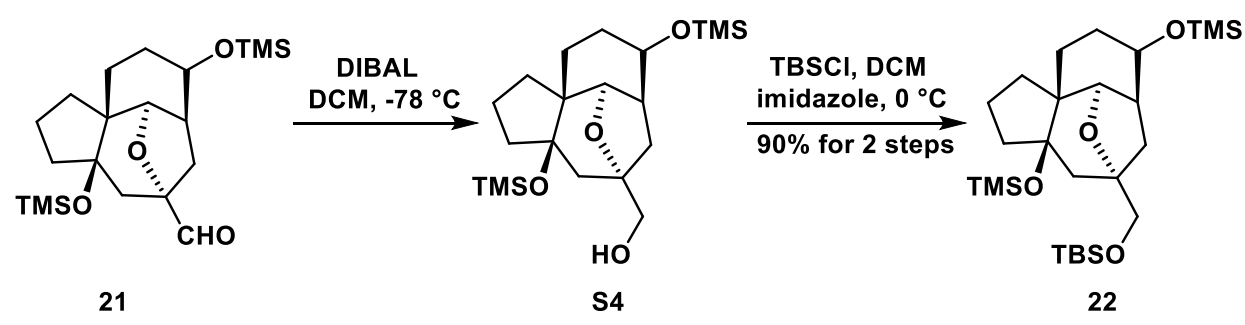

The compound 21 (220 mg, $0.55 \mathrm{mmol}, 1.0$ equiv.) was dissolved in dry DCM (5.5 mL, $0.1 \mathrm{M})$ at $-78{ }^{\circ} \mathrm{C}$. Diisobutylaluminum hydride (1.5 M in toluene, $0.81 \mathrm{~mL}, 1.21 \mathrm{mmol} .2 .2$ equiv.) was added dropwise and the solution 
was stirred at $-78{ }^{\circ} \mathrm{C}$ for $1.5 \mathrm{~h}$. The reaction was quenched with EtOAc and saturated aqueous potassium tartrate tetrahydrate $(5 \mathrm{~mL})$. Stirring was continued until the solution was clear and extracted with $\mathrm{DCM}(3 \times 10 \mathrm{~mL})$. The combined extracts were dried by $\mathrm{Na}_{2} \mathrm{SO}_{4}$, filtered, concentrated. The crude product $\mathbf{S} \mathbf{4}$ was used for the next step without further purification.

To a solution of alcohol S4 in DCM (5.5 mL, 0.1 M) was added imidazole (122 mg, $1.65 \mathrm{mmol}, 3.0$ equiv.) and TBSCl (166.0 mg, $1.1 \mathrm{mmol}, 2.0$ equiv.) at $0{ }^{\circ} \mathrm{C}$. The reaction mixture was stirred for 3 hours, and TLC showed the consumption of the starting material. The reaction mixture was quenched by saturated aqueous $\mathrm{NaHCO}_{3}(5 \mathrm{~mL})$. The mixture was extracted with DCM $(3 \times 10 \mathrm{~mL})$. The combined organic layers were dried over $\mathrm{Na}_{2} \mathrm{SO}_{4}$, filtered, and concentrated under reduced pressure. Purification of the crude product by flash-column chromatography on silica gel (hexane/EtOAc, 30:1 10:1) afford 22 (253 $\mathrm{mg}, 90 \%$ for 2 steps) as a colorless oil.

$\boldsymbol{R}_{\boldsymbol{f}}=0.31$ (hexane: EtOAc $=30: 1$ );

IR (film) $\lambda \max 2956,1755,1728,1433,1253,1080,870 \mathrm{~cm}^{-1}$;

${ }^{1} \mathrm{H}$ NMR $\left(500 \mathrm{MHz}, \mathrm{CDCl}_{3}\right) \delta 4.09-4.02(\mathrm{~m}, 2 \mathrm{H}), 3.87-3.77(\mathrm{~m}, 2 \mathrm{H}), 3.52-3.46(\mathrm{~m}, 3 \mathrm{H}), 2.57-2.47(\mathrm{~m}, 1 \mathrm{H})$, $2.28-2.17(\mathrm{~m}, 1 \mathrm{H}), 2.12-2.01(\mathrm{~m}, 2 \mathrm{H}), 1.98-1.82(\mathrm{~m}, 5 \mathrm{H}), 1.71-1.64(\mathrm{~m}, 9 \mathrm{H}), 1.54-1.23(\mathrm{~m}, 13 \mathrm{H}), 0.94-0.89$ (m, 18H), $0.13-0.12(\mathrm{~m}, 18 \mathrm{H}), 0.09-0.08(\mathrm{~m}, 18 \mathrm{H}), 0.07-0.05(\mathrm{~m}, 12 \mathrm{H}) \mathrm{ppm}$;

${ }^{13} \mathrm{C}$ NMR $\left(125 \mathrm{MHz}, \mathrm{CDCl}_{3}\right) \delta 85.1,82.1,81.7,81.5,81.03,80.96,70.18,70.15,69.3,69.0,47.5,47.41,47.39,46.5$, $46.4,45.9,45.5,44.8,44.6,43.6,33.3,31.9,31.9,29.5,27.9,27.2,26.10,26.05,22.3,21.9,18.52,18.45,2.64,2.62$, $1.2,0.5,0.3,-5.18,-5.20 \mathrm{ppm}$;

HRMS (ESI) $\mathrm{C}_{26} \mathrm{H}_{53} \mathrm{O}_{4} \mathrm{Si}_{3}[\mathrm{M}+\mathrm{H}]^{+}:$513.3252, found 513. 3257.

\section{Synthesis of compound 23}
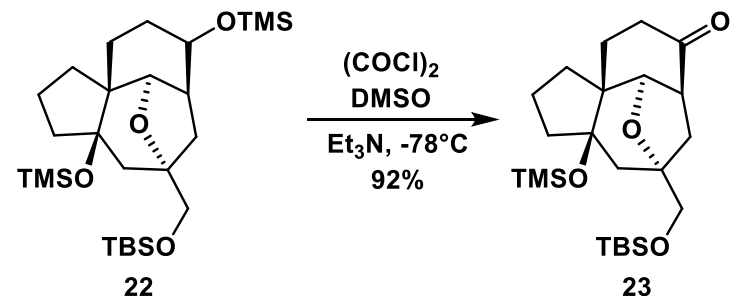

Oxalyl dichloride $\left(0.025 \mathrm{~mL}, 37 \mathrm{mg}, 0.29 \mathrm{mmol}, 1.16\right.$ equiv.) was stirred in dry DCM $(2 \mathrm{~mL})$ at $-78{ }^{\circ} \mathrm{C}$ under nitrogen. A solution of dimethyl sulfoxide $(0.05 \mathrm{~mL}, 55 \mathrm{mg}, 0.70 \mathrm{mmol}, 2.8$ equiv.) in dry DCM was added dropwise over a period of $15 \mathrm{~min}$, keeping the internal temperature below $-60{ }^{\circ} \mathrm{C}$. The mixture was stirred for $5 \mathrm{~min}$, then a solution of 22 (129 mg, $0.25 \mathrm{mmol}, 1.0$ equiv.) in dry DCM (2 mL) was added dropwise over a period of $15 \mathrm{~min}$, maintaining the same temperature. After stirring of the mixture at $-78{ }^{\circ} \mathrm{C}$ for $2 \mathrm{~h}, \mathrm{Et}_{3} \mathrm{~N}(0.5 \mathrm{~mL})$ was added over a period of $5 \mathrm{~min}$ and the mixture was stirred at $-78^{\circ} \mathrm{C}$ for a further $30 \mathrm{~min}$, then allowed to warm to $25^{\circ} \mathrm{C}$. Water $(2$ $\mathrm{mL})$ and DCM $(2 \mathrm{~mL})$ were successively added and the mixture was stirred for $25 \mathrm{~min}$. The mixture was extracted with $\mathrm{DCM}(3 \times 5 \mathrm{~mL})$ and the combined organic layers were dried over $\mathrm{Na}_{2} \mathrm{SO}_{4}$, filtered and concentrated under reduced pressure. Purification of the crude product by flash-column chromatography on silica gel (hexane/Et ${ }_{2} \mathrm{O}, 2: 1$ ) afford $\mathbf{2 3}$ (117 mg, 92\%) as a colorless oil. 
$\boldsymbol{R}_{\boldsymbol{f}}=0.3$ (hexane: $\mathrm{Et}_{2} \mathrm{O}=2: 1$ );

IR (film) $\lambda \max 2957,1708,1469,1251,1130,1100,825 \mathrm{~cm}^{-1}$;

${ }^{1} \mathbf{H}$ NMR $\left(500 \mathrm{MHz}, \mathrm{CDCl}_{3}\right) \delta 4.24(\mathrm{~d}, J=7.9 \mathrm{~Hz}, 1 \mathrm{H}), 3.56(\mathrm{~s}, 2 \mathrm{H}), 2.96-2.92(\mathrm{~m}, 1 \mathrm{H}), 2.50-2.41(\mathrm{~m}, 1 \mathrm{H}), 2.30$ $(\mathrm{dd}, J=12.3,4.4 \mathrm{~Hz}, 1 \mathrm{H}), 2.26-2.17(\mathrm{~m}, 3 \mathrm{H}), 2.08(\mathrm{t}, J=12.9 \mathrm{~Hz}, 1 \mathrm{H}), 1.92(\mathrm{dd}, J=12.4,10.3 \mathrm{~Hz}, 1 \mathrm{H}), 1.76-$ $1.66(\mathrm{~m}, 4 \mathrm{H}), 1.58-1.49(\mathrm{~m}, 2 \mathrm{H}), 1.44-1.35(\mathrm{~m}, 1 \mathrm{H}), 0.88$ (s, 9H), $0.10(\mathrm{~s}, 9 \mathrm{H}), 0.05$ (s, 6H) ppm;

${ }^{13}$ C NMR $\left(125 \mathrm{MHz}, \mathrm{CDCl}_{3}\right) \delta$ 212.2, 82.4, 81.5, 78.9, 69.1, 49.5, 45.3, 43.1, 40.1, 37.0, 35.2, 34.7, 29.5, 26.0, 19.2, $18.4,2.3,-5.2,-5.3 \mathrm{ppm}$;

HRMS (ESI) $\mathrm{C}_{23} \mathrm{H}_{43} \mathrm{O}_{4} \mathrm{Si}_{2}[\mathrm{M}+\mathrm{H}]^{+}: 439.2700$, found 439.2705 .

\section{Synthesis of compound 24}

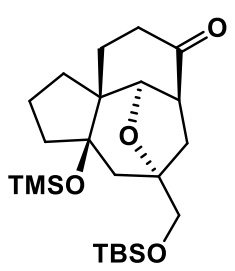

23

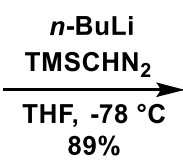

$89 \%$

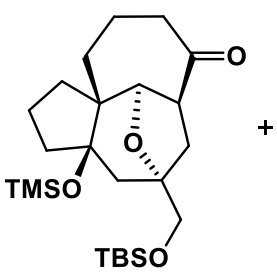

24a

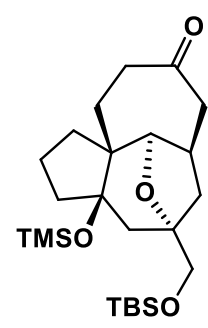

24b

$n$-BuLi (2.5M solution in hexanes, $67.0 \mu \mathrm{L}, 0.168 \mathrm{mmol}, 1.5$ equiv.) was added to THF ( $2 \mathrm{~mL})$ at $-78^{\circ} \mathrm{C}$, followed by the addition of $\mathrm{TMSCHN}_{2}\left(2.0 \mathrm{M}\right.$ solution in hexanes, $84.0 \mu \mathrm{L}, 0.168 \mathrm{mmol}, 1.5$ equiv). ${ }^{2}$ The mixture was stirred for 15 minutes, before ketone 23 (49 mg, 0.112 mol, 1.0 equiv.) was added in THF (4.0 mL). The reaction mixture was stirred for 45 minutes at $-78^{\circ} \mathrm{C}$, before the addition of $\mathrm{MeOH}(1 \mathrm{~mL} \mathrm{MeOH}$ in $1 \mathrm{~mL} \mathrm{THF})$ at $-78^{\circ} \mathrm{C}$ quenched the reaction. The reaction mixture was diluted with EtOAc $(2 \mathrm{~mL})$ and $1 \mathrm{MNaOH}(2 \mathrm{~mL})$. The layers were separated, and the aqueous layer was extracted with EtOAc $(3 \times 5 \mathrm{~mL})$. The combined organic layers were dried over $\mathrm{MgSO}_{4}$ and silica gel (2.0 g) was added to the solution. The mixture was stirred for 30 minutes, leading to homologation and resulting in a mixture of homologated ketone and its enol-ether derivative. The solvent was removed under reduced pressure. The remains were re-dissolved in EtOAc. The organic layer was extracted three times with $1 \mathrm{M} \mathrm{HCl} \mathrm{solution}$. The organic phase containing the non-aminic remains was then discarded. The acidic phase was then adjusted to basic $\mathrm{pH}$ with $2 \mathrm{M} \mathrm{NaOH}$ solution $(2 \mathrm{~mL})$. The basic phase was extracted three times with EtOAc $(3 \times 5 \mathrm{~mL})$. The combined organic layers were dried over $\mathrm{MgSO}_{4}$ and the solvent was removed under reduced pressure. Purification of the crude product by flash-column chromatography on silica gel (hexane/Et $\left.{ }_{2} \mathrm{O}, 4: 1\right)$ to afford 24 (46 mg, $89 \%$, $\mathbf{2 4 a : 2 4 b}=6: 1)$ as a colorless oil.

Data of major 24a

$\boldsymbol{R}_{\boldsymbol{f}}=0.3$ (hexane: $\mathrm{Et}_{2} \mathrm{O}=4: 1$ );

IR (film) $\lambda \max 2953,2927,2856,1710,1471,1359,1251,1126,1105,837,777 \mathrm{~cm}^{-1}$;

${ }^{1} \mathbf{H}$ NMR $\left(500 \mathrm{MHz}, \mathrm{CDCl}_{3}\right) \delta 4.25(\mathrm{~d}, J=7.4 \mathrm{~Hz}, 1 \mathrm{H}), 3.52(\mathrm{~s}, 2 \mathrm{H}), 3.21(\mathrm{dd}, J=12.5,6.4 \mathrm{~Hz}, 1 \mathrm{H}), 2.57(\mathrm{dd}, J=$ 12.3, 5.7 Hz, 1H), $2.52-2.33(\mathrm{~m}, 4 \mathrm{H}), 2.25-2.19(\mathrm{~m}, 1 \mathrm{H}), 2.17-2.10(\mathrm{~m}, 1 \mathrm{H}), 2.01-1.94(\mathrm{~m}, 1 \mathrm{H}), 1.93-1.86(\mathrm{~m}$, 
1H), $1.81-1.69(\mathrm{~m}, 3 \mathrm{H}), 1.67-1.63(\mathrm{~m}, 1 \mathrm{H}), 1.57-1.52(\mathrm{~m}, 1 \mathrm{H}), 1.44-1.36(\mathrm{~m}, 1 \mathrm{H}), 1.21-1.14(\mathrm{~m}, 1 \mathrm{H}), 0.89(\mathrm{~s}$, 9H), 0.12 (s, 9H), 0.05 (s, 6H) ppm;

${ }^{13} \mathbf{C}$ NMR $\left(125 \mathrm{MHz}, \mathrm{CDCl}_{3}\right) \delta 210.0,83.0,82.5,78.6,69.3,57.0,51.2,44.7,43.0,39.2,37.5,35.1,32.7,26.0,23.1$, $18.4,17.6,2.7,-5.2,-5.2 \mathrm{ppm}$;

HRMS (ESI) $\mathrm{C}_{24} \mathrm{H}_{45} \mathrm{O}_{4} \mathrm{Si}_{2}[\mathrm{M}+\mathrm{H}]^{+}: 453.2851$,found : 453.2850 .

\section{Synthesis of compound 25}

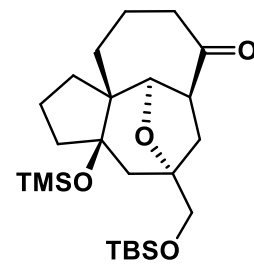

$24 a$

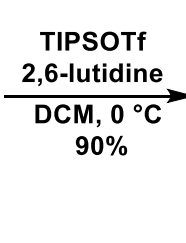

$90 \%$

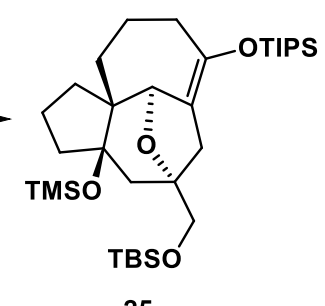

25

TIPSOTf (13.5 mg, $0.044 \mathrm{mmol}, 2.0$ equiv.) was added to a mixture of compound $\mathbf{2 4 a}$ (10 $\mathrm{mg}, 0.022 \mathrm{mmol}, 1.0$ equiv.) and 2,6-lutidine (7.1 mg, $0.066 \mathrm{mmol}, 3.0$ equiv.) in DCM $(2 \mathrm{~mL})$ at $0{ }^{\circ} \mathrm{C}$. After $14 \mathrm{~h}$ of stirring at $25^{\circ} \mathrm{C}$, the reaction was quenched with saturated aqueous $\mathrm{NaHCO}_{3}(2 \mathrm{~mL})$ and the resulting mixture was extracted with EtOAc $(3 \times 5 \mathrm{~mL})$. The combined organic extracts were washed with brine and dried over anhydrous $\mathrm{Na}_{2} \mathrm{SO}_{4}$. Filtration and evaporation in vacuum furnished the crude product. Purification of the crude product by flash-column chromatography on silica gel (hexane/EtOAc $=50: 1 \sim 3: 1)$ give silyl enol ether $25(12.0 \mathrm{mg}, 90 \%)$ as colorless oil.

$\boldsymbol{R}_{\boldsymbol{f}}=0.3$ (hexane: $\mathrm{EtOAc}=50: 1$ );

${ }^{1} \mathbf{H}$ NMR $\left(500 \mathrm{MHz}, \mathrm{CDCl}_{3}\right) \delta 4.41(\mathrm{~s}, 1 \mathrm{H}), 3.60-3.53(\mathrm{~m}, 2 \mathrm{H}), 2.58(\mathrm{~d}, J=14.3 \mathrm{~Hz}, 1 \mathrm{H}), 2.41(\mathrm{dd}, J=14.8,10.4$ $\mathrm{Hz}, 1 \mathrm{H}), 2.25(\mathrm{~d}, J=14.4 \mathrm{~Hz}, 1 \mathrm{H}), 2.17-2.10(\mathrm{~m}, 2 \mathrm{H}), 2.00-1.85(\mathrm{~m}, 3 \mathrm{H}), 1.76(\mathrm{~d}, J=14.1 \mathrm{~Hz}, 1 \mathrm{H}), 1.68-1.62$ $(\mathrm{m}, 2 \mathrm{H}), 1.49-1.40(\mathrm{~m}, 2 \mathrm{H}), 1.35-1.18(\mathrm{~m}, 3 \mathrm{H}), 1.13-1.10(\mathrm{~m}, 3 \mathrm{H}), 1.09-1.05(\mathrm{~m}, 18 \mathrm{H}), 0.91-0.85(\mathrm{~m}, 9 \mathrm{H})$, $0.11-0.08(\mathrm{~m}, 9 \mathrm{H}), 0.06-0.04(\mathrm{~m}, 6 \mathrm{H}) \mathrm{ppm}$;

${ }^{13} \mathbf{C}$ NMR $\left(125 \mathrm{MHz}, \mathrm{CDCl}_{3}\right) \delta 142.8,118.2,82.9,82.3,80.1,69.2,48.3,42.8,40.3,37.6,37.3,35.7,35.3,26.0$, 22.4, 18.8, 18.5, 18.2, 13.1, 2.7, -5.2, -5.3 ppm;

HRMS (ESI) $\mathrm{C}_{33} \mathrm{H}_{65} \mathrm{O}_{4} \mathrm{Si}_{3}[\mathrm{M}+\mathrm{H}]^{+}:$609.4185, found 609.4196 .

\section{Synthesis of compound 27}

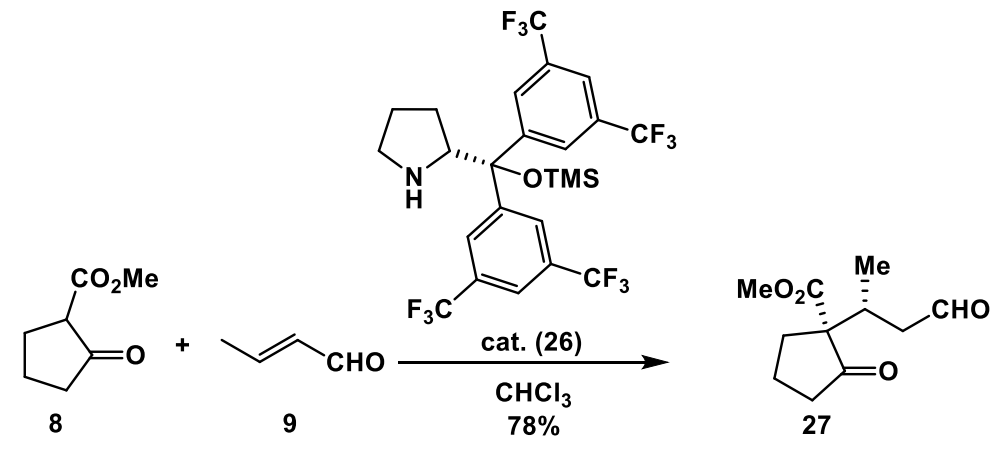


To a solution of $\beta$-keto ester 8 (11.0 g, $77.5 \mathrm{mmol}, 1.0$ equiv.) in $\mathrm{CHCl}_{3}(300 \mathrm{~mL}, 0.26 \mathrm{M})$ was added 3,5bistrifluoromethyl diphenyl prolinol TMS ether catalyst $\mathbf{2 6}^{3}(9.2 \mathrm{~g}, 15.5 \mathrm{mmol}, 0.2$ equiv.), followed by crotonaldehyde (9, $6.5 \mathrm{~g}, 93.0 \mathrm{mmol}, 1.2$ equiv.). The mixture was stirred at $25{ }^{\circ} \mathrm{C}$ for 24 hours. The solution was concentrated under reduced pressure. The residue was purified by flash-column chromatography on silica gel (hexanes/Et $2 \mathrm{O}, 1: 1 \sim 3: 4)$ to provide $27(12.82 \mathrm{~g}, 78 \%$ ).

$\boldsymbol{R}_{\boldsymbol{f}}=0.3$ (hexane: $\mathrm{EtOAc}=5: 1$ );

${ }^{1}$ H NMR $\left(400 \mathrm{MHz}, \mathrm{CDCl}_{3}\right) \delta 9.68-9.66(\mathrm{~m}, 1 \mathrm{H}), 3.68(\mathrm{~s}, 3 \mathrm{H}), 2.98-2.83(\mathrm{~m}, 1 \mathrm{H}), 2.69(\mathrm{dd}, J=16.9,3.6 \mathrm{~Hz}$, $1 \mathrm{H}), 2.49-2.37(\mathrm{~m}, 2 \mathrm{H}), 2.26-2.11(\mathrm{~m}, 2 \mathrm{H}), 2.02-1.86(\mathrm{~m}, 3 \mathrm{H}), 0.89(\mathrm{~d}, J=6.6 \mathrm{~Hz}, 3 \mathrm{H}) \mathrm{ppm}$;

${ }^{13} \mathrm{C}$ NMR $\left(100 \mathrm{MHz}, \mathrm{CDCl}_{3}\right) \delta 214.2,201.2,170.7,63.9,52.8,47.2,38.8,31.3,29.5,19.6,16.1 \mathrm{ppm}$;

HRMS (ESI) $\mathrm{C}_{11} \mathrm{H}_{17} \mathrm{O}_{4}[\mathrm{M}+\mathrm{H}]^{+}: 213.1121$, found: 213.1116.

\section{Synthesis of compound 28}

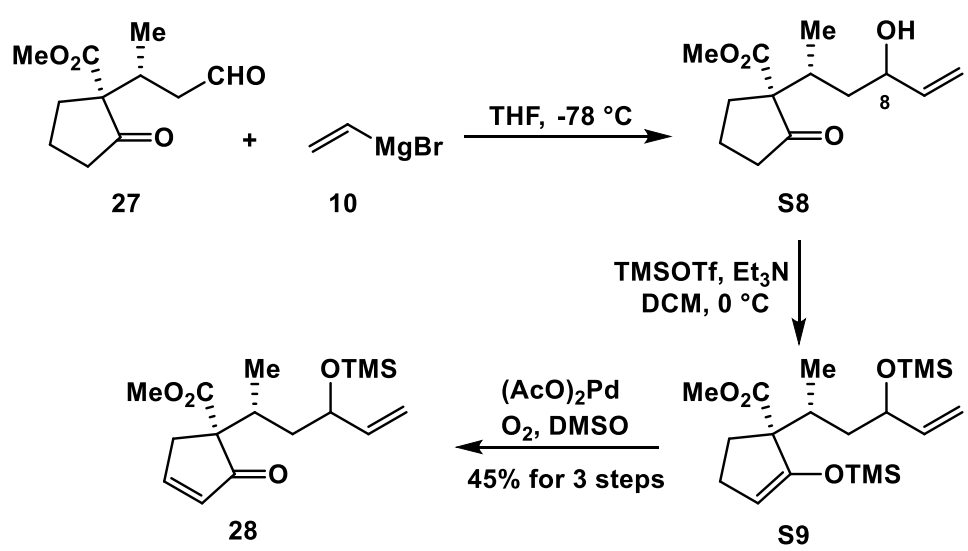

To a stirred solution of 27 (11.9 g, $56.1 \mathrm{mmol}, 1.0$ equiv.) in THF (280 mL, $0.2 \mathrm{M})$ was added dropwise vinylmagnesium bromide ( $1 \mathrm{M}$ in THF, $61.7 \mathrm{~mL}, 61.7 \mathrm{mmol}, 1.1$ equiv.) at $-78^{\circ} \mathrm{C}$ and the reaction mixture was stirred at $-78^{\circ} \mathrm{C}$ for 1.0 hour. Following quenching with saturated aqueous $\mathrm{NH}_{4} \mathrm{Cl}(200 \mathrm{~mL})$, the reaction mixture was extracted EtOAc $(3 \times 200 \mathrm{~mL})$. The organic layer filtrated through a pad of celite by the aid of EtOAc and organic layers were dried over $\mathrm{MgSO}_{4}$, filtered and concentrated under reduced pressure to give $\mathbf{S 8}$, which was used for the next step without further purification.

TMSOTf (12.8 g, 117.8 mmol, 2.1 equiv.) was added to alcohol $\mathbf{S 8}$ and $\mathrm{Et}_{3} \mathrm{~N}$ (14.2 g, 140.25 mmol, 2.5 equiv.) in $\operatorname{DCM}(280 \mathrm{~mL}, 0.2 \mathrm{M})$ at $0{ }^{\circ} \mathrm{C}$. After $14 \mathrm{~h}$ of stirring at $25{ }^{\circ} \mathrm{C}$, the reaction was quenched with saturated aqueous $\mathrm{NaHCO}_{3}(100 \mathrm{~mL})$, and the resulting mixture was extracted with DCM $(3 \times 150 \mathrm{~mL})$. The combined organic extracts were washed with brine and dried over anhydrous $\mathrm{Na}_{2} \mathrm{SO}_{4}$. Filtration and evaporation in vacuo furnished the crude product. The residue was purified quickly by column chromatography on silica gel (hexanes/EtOAc, 20:1 10:1) to afford the desired compound and an inseparable mixture of unidentified byproducts. The desired TMS ether S9 was not characterized and was used directly in the next step.

To a stirred solution of $\mathbf{S 9}$ (1.8 g, $4.7 \mathrm{mmol}, 1.0$ equiv.) in DMF $(4.7 \mathrm{~mL}, 0.1 \mathrm{M})$ was added $\mathrm{Pd}(\mathrm{OAc})_{2}(58 \mathrm{mg}$, $0.26 \mathrm{mmol}, 0.055$ equiv.) at $25^{\circ} \mathrm{C}$ and the tube was evacuated and backfilled with oxygen (repeated three times). The 
reaction mixture was stirring at $25^{\circ} \mathrm{C}$ for 24 hours. Following added with $\mathrm{H}_{2} \mathrm{O}(10 \mathrm{~mL})$, the reaction mixture was extracted EtOAc $(3 \times 20 \mathrm{~mL})$. The combined organic extracts were washed with brine and dried over anhydrous $\mathrm{Na}_{2} \mathrm{SO}_{4}$. Filtration and evaporation in vacuo furnished the crude product. The residue was purified quickly by column chromatography on silica gel (hexanes/EtOAc, 10:1 5:1 giving $28(1.2 \mathrm{~g})$ as a yellow oil.

Note: Treatment of aldehyde $\mathbf{2 7}$ with vinylmagnesium bromide led to the formation $\mathbf{S 8}$ as a pair of inseparable diastereomers (1:1 d.r.). Both diastereomers could be useful for the subsequent synthesis. According to the above procedure, a total of $9.4 \mathrm{~g}$ of $\mathbf{2 8}$ was prepared readily after 5 simple parallel operations ( $45 \%$ for 3 steps).

$\boldsymbol{R}_{f}=0.3$ (hexane: EtOAc $=20: 1$ );

IR (film) $\lambda \max 2955,1714,1595,1433,1344,1249,1153,1065,929,843,756 \mathrm{~cm}^{-1}$;

${ }^{1} \mathbf{H}$ NMR $\left(500 \mathrm{MHz}, \mathrm{CDCl}_{3}\right) \delta 7.83-7.76(\mathrm{~m}, 2 \mathrm{H}), 6.14-6.10(\mathrm{~m}, 2 \mathrm{H}), 5.81-5.70(\mathrm{~m}, 2 \mathrm{H}), 5.18-5.00(\mathrm{~m}, 4 \mathrm{H})$, $4.19-4.08(\mathrm{~m}, 2 \mathrm{H}), 3.70(\mathrm{~d}, J=12.0 \mathrm{~Hz}, 6 \mathrm{H}), 3.26(\mathrm{~m}, 2 \mathrm{H}), 2.73-2.54(\mathrm{~m}, 4 \mathrm{H}), 1.42-1.14(\mathrm{~m}, 4 \mathrm{H}), 0.80-0.75$ (m, 6H), $0.10(\mathrm{~d}, J=2.6 \mathrm{~Hz}, 18 \mathrm{H}) \mathrm{ppm}$;

${ }^{13} \mathrm{C}$ NMR $\left(126 \mathrm{MHz}, \mathrm{CDCl}_{3}\right) \delta$ 205.324, 205.322, 170.7, 170.4, 165.3, 164.8 141.7, 140.5, 133.1, 132.8, 115.5, $114.1,73.3,71.7,63.7,63.2,52.98,52.95,41.7,41.4,35.6,35.0,33.9,33.4,14.4,14.2,0.43$ ppm;

HRMS (ESI) calc. for $\mathrm{C}_{16} \mathrm{H}_{27} \mathrm{O}_{4} \mathrm{Si}[\mathrm{M}+\mathrm{H}]^{+}: 311.1673$, found: 311.1667 .

\section{Synthesis of compound 7}
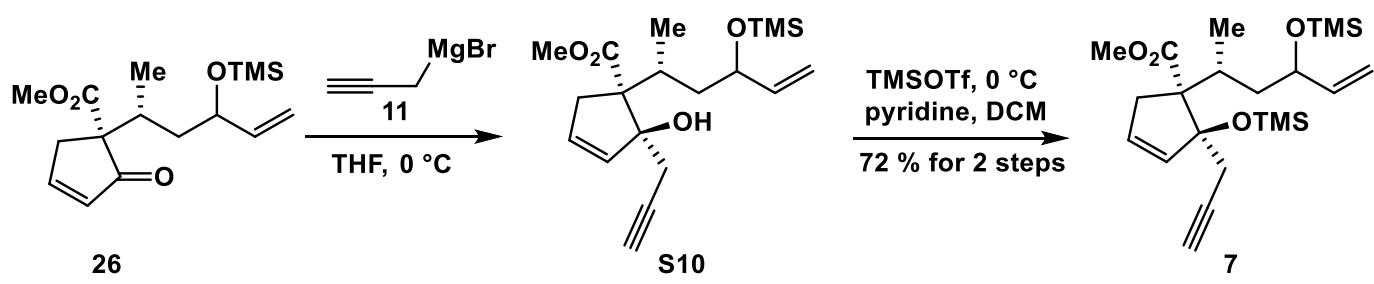

To a stirred solution of compound $\mathbf{2 6}(9.3 \mathrm{~g}, 30 \mathrm{mmol}, 1.0$ equiv. $)$ in THF (100 $\mathrm{mL}, 0.3 \mathrm{M})$ was added dropwise propargylmagnesium bromide (11, $0.5 \mathrm{M}$ in $\mathrm{Et}_{2} \mathrm{O}, 60 \mathrm{mmol}, 2.0$ equiv.) at $0{ }^{\circ} \mathrm{C}$ and the reaction mixture was stirred at $25{ }^{\circ} \mathrm{C}$ for $3 \mathrm{~h}$. Following quenching with saturated aqueous $\mathrm{NH}_{4} \mathrm{Cl}(10 \mathrm{~mL})$, the reaction mixture was extracted by EtOAc $(3 \times 100 \mathrm{~mL})$, dried over $\mathrm{MgSO}_{4}$, and evaporated under reduced pressure to give oil $\mathbf{S 1 0}$, which was used for the next step without further purification.

TMSOTf (10.0 g, 45 mmol, 1.5 equiv.) was added to $\mathbf{S 1 0}$ and pyridine ( $4.7 \mathrm{~g}, 60 \mathrm{mmol}, 2.0$ equiv.) in DCM (100 $\mathrm{mL}, 0.3 \mathrm{M})$ at $0{ }^{\circ} \mathrm{C}$. After $10 \mathrm{~h}$ of stirring at $25{ }^{\circ} \mathrm{C}$, the reaction was quenched with saturated aqueous $\mathrm{NaHCO}_{3}(10$ $\mathrm{mL})$, and the resulting mixture was extracted with EtOAc $(3 \times 100 \mathrm{~mL})$. The combined organic extracts were washed with brine $(50 \mathrm{~mL})$ and dried over anhydrous $\mathrm{Na}_{2} \mathrm{SO}_{4}$. The dried solution was filtered and concentrated. The residue obtained was purified by flash-column chromatography on silica gel (hexanes/EtOAc, 20:1 10:1) give TMS ether $7(9.1 \mathrm{~g}, 72 \%$ for 2 steps) as a yellow oil.

$\boldsymbol{R}_{\boldsymbol{f}}=0.6$ (hexane: EtOAc $=10: 1$ ); 
${ }^{1} \mathrm{H}$ NMR $\left(500 \mathrm{MHz}, \mathrm{CDCl}_{3}\right) \delta 5.92-5.60(\mathrm{~m}, 6 \mathrm{H}), 5.13-4.96(\mathrm{~m}, 4 \mathrm{H}), 4.18-3.99(\mathrm{~m}, 2 \mathrm{H}), 3.68(\mathrm{~s}, 3 \mathrm{H}), 3.67(\mathrm{~s}$, $3 \mathrm{H}), 2.99(\mathrm{dt}, J=17.2,2.0 \mathrm{~Hz}, 2 \mathrm{H}), 2.56-2.38(\mathrm{~m}, 6 \mathrm{H}), 2.25-2,17(\mathrm{~m}, 2 \mathrm{H}), 1.99-1.94(\mathrm{~m}, 2 \mathrm{H}), 1.47-1.22(\mathrm{~m}$, $4 \mathrm{H}), 0.88(\mathrm{~d}, J=6.7 \mathrm{~Hz}, 3 \mathrm{H}), 0.84(\mathrm{~d}, J=6.7 \mathrm{~Hz}, 3 \mathrm{H}), 0.16(\mathrm{~s}, 18 \mathrm{H}), 0.10(\mathrm{~d}, J=7.2 \mathrm{~Hz}, 18 \mathrm{H}) \mathrm{ppm}$;

${ }^{13} \mathbf{C}$ NMR $\left(125 \mathrm{MHz}, \mathrm{CDCl}_{3}\right) \delta 175.7,175.5,142.6,141.2,134.7,134.6,130.9,130.8,114.6,113.5,88.4,88.3,81.4$, 81.3, 73.9, 72.2, 70.9, 70.9, 65.4, 65.3, 51.7, 51.6, 41.45, 41.37, 36.7, 36.3, 34.5, 33.6, 31.12, 31.09, 17.5, 16.8, 2.50, 2.48, 0.6, $0.5 \mathrm{ppm}$;

HRMS (ESI) calc. for $\mathrm{C}_{22} \mathrm{H}_{39} \mathrm{O}_{4} \mathrm{Si}_{2}[\mathrm{M}+\mathrm{H}]^{+}: 423.2381$, found: 423.2370 .

\section{Synthesis of compound 29}

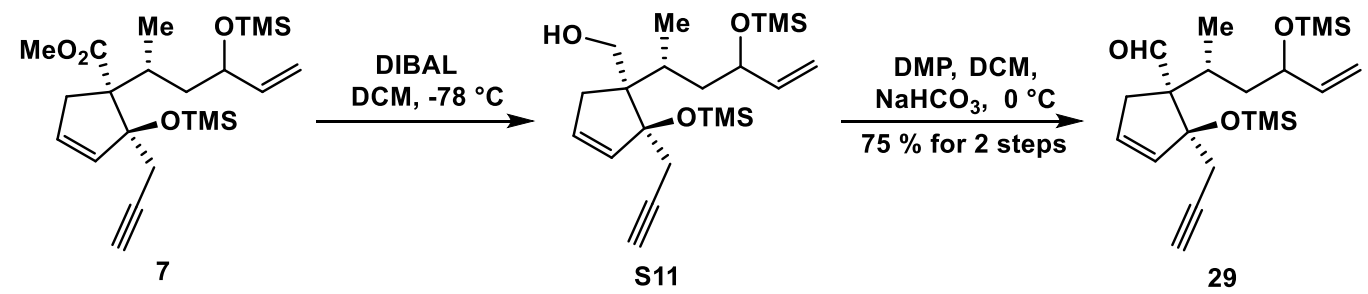

The compound 7 (3.6 g, $8.5 \mathrm{mmol}, 1.0$ equiv.) was dissolved in dry DCM (40 mL, $0.21 \mathrm{M})$ at $-78{ }^{\circ} \mathrm{C}$. Diisobutylaluminum hydride (1.5 M in toluene, $11.3 \mathrm{~mL}, 17 \mathrm{mmol}, 2.0$ equiv.) was added dropwise and the solution was stirred at $-78^{\circ} \mathrm{C}$ for $1.5 \mathrm{~h}$. The reaction was quenched with EtOAc and saturated aqueous potassium tartrate tetrahydrate $(40 \mathrm{~mL})$. Stirring was continued until the solution was clear and extracted with DCM $(3 \times 50 \mathrm{~mL})$. The combined extracts were dried by $\mathrm{Na}_{2} \mathrm{SO}_{4}$, filtered, concentrated, and evaporation in vacuum furnished the crude product S11 as a yellow oil, which was used for the next step without further purification.

To a solution of compound $\mathbf{S 1 1}$ in DCM (40 mL, $0.21 \mathrm{M})$ was added $\mathrm{NaHCO}_{3}(3.6 \mathrm{~g}, 42.5 \mathrm{mmol}, 5.0$ equiv.) at $0{ }^{\circ} \mathrm{C}$, and Dess-Martin reagent $(7.2 \mathrm{~g}, 17 \mathrm{mmol}, 2.0$ equiv.) in small portions. The resulting mixture was stirred at the same temperature for 3.0 hours. The reaction was then quenched with saturated aqueous solution $\mathrm{Na}_{2} \mathrm{~S}_{2} \mathrm{O}_{3}(20 \mathrm{~mL})$ and $\mathrm{NaHCO}_{3}(20 \mathrm{~mL})$, and extracted with $\mathrm{DCM}(3 \times 60 \mathrm{~mL})$. The combined organic layers were dried over $\mathrm{Na}_{2} \mathrm{SO}_{4}$, and solvents were removed under vacuum. The obtained residue was purified by flash-chromatography on silica gel (hexane/EtOAc, 30:1) to give $\mathbf{2 9}$ (2.5 g, $75 \%$ for 2 steps) as a yellow oil.

$\boldsymbol{R}_{f}=0.4$ (hexane: $\mathrm{EtOAc}=30: 1$ );

IR (film) $\lambda \max 3311,2954,1728,1433,1249,1153,1080,929,840,754 \mathrm{~cm}^{-1}$;

${ }^{1} \mathbf{H}$ NMR $\left(500 \mathrm{MHz}, \mathrm{CDCl}_{3}\right) \delta 9.72(\mathrm{~d}, J=3.2 \mathrm{~Hz}, 2 \mathrm{H}), 5.95-5.72(\mathrm{~m}, 6 \mathrm{H}), 5.17-4.98(\mathrm{~m}, 4 \mathrm{H}), 4.21-4.09(\mathrm{~m}$, 2H), $2.93-2.84(\mathrm{~m}, 2 \mathrm{H}), 2.73-2.52(\mathrm{~m}, 2 \mathrm{H}), 2.51-2.39(\mathrm{~m}, 3 \mathrm{H}), 2.17-2.07(\mathrm{~m}, 2 \mathrm{H}), 2.03-2.01(\mathrm{~m}, 2 \mathrm{H}), 1.94-$ $1.68(\mathrm{~m}, 2 \mathrm{H}), 1.68-1.60(\mathrm{~m}, 1 \mathrm{H}), 1.36-1.24(\mathrm{~m}, 2 \mathrm{H}), 0.92-0.88(\mathrm{~m}, 6 \mathrm{H}), 0.19-0.06(\mathrm{~m}, 36 \mathrm{H}) \mathrm{ppm}$;

${ }^{13} \mathrm{C}$ NMR $\left(125 \mathrm{MHz}, \mathrm{CDCl}_{3}\right) \delta 205.3,204.6,142.5,141.1,135.1,134.8,133.1,132.5,115.1,113.6,88.1,87.8,81.0$, 80.9, 73.9, 71.7, 71.6, 66.9, 66.7, 40.4, 40.2, 36.7, 35.5, 33.6, 32.0, 30.8, 30.7, 16.5, 15.8, 2.5, 2.3, 1.2, 0.6, 0.5 ppm; HRMS (ESI) calcd. for $\mathrm{C}_{21} \mathrm{H}_{37} \mathrm{O}_{3} \mathrm{Si}_{2}[\mathrm{M}+\mathrm{H}]^{+}:$393.2276, found: 393.2280 .

\section{Synthesis of compound 6}




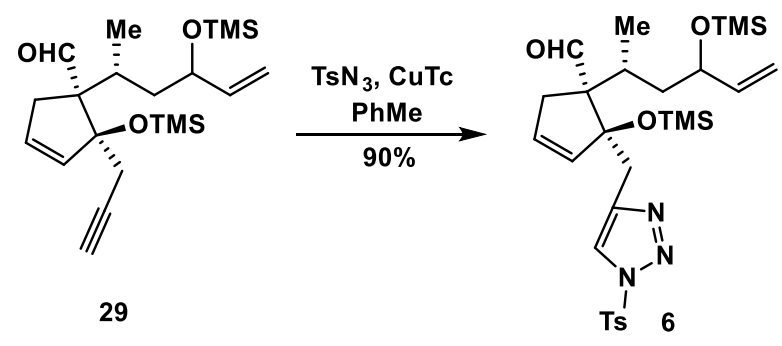

To a solution of compound 29 (1.96 g, $5.0 \mathrm{mmol}, 1.0$ equiv.) in dry PhMe (50 mL, $0.1 \mathrm{M})$ was added copper(I) thiophene-2-carboxylate ( $96 \mathrm{mg}, 0.5 \mathrm{mmol}, 0.1$ equiv.), followed by addition of tosyl azide (1.08 g, $5.5 \mathrm{mmol}, 1.1$ equiv.) in a dropwise manner at $25{ }^{\circ} \mathrm{C}$. The reaction mixture was then stirred at the same temperature for $6 \mathrm{~h}$. Then the organics were evaporated, diluted with a minimal amount of DCM, loaded directly onto a silica gel column (hexane/EtOAc, $5: 1)$ to give 6 (2.65 g, 90\%) as a colorless oil.

$\boldsymbol{R}_{f}=0.3$ (hexane: $\mathrm{EtOAc}=5: 1$ );

${ }^{1} \mathbf{H}$ NMR $\left(400 \mathrm{MHz}, \mathrm{CDCl}_{3}\right) \delta 9.72-9.56(\mathrm{~m}, 2 \mathrm{H}), 8.01(\mathrm{~d}, J=1.2 \mathrm{~Hz}, 2 \mathrm{H}), 7.98-7.90(\mathrm{~m}, 2 \mathrm{H}), 7.86-7.83(\mathrm{~m}$, 2H), $7.42-7.37$ (m, 4H), $5.99-5.88(\mathrm{~m}, 2 \mathrm{H}), 5.89-5.73(\mathrm{~m}, 4 \mathrm{H}), 5.19-5.02(\mathrm{~m}, 4 \mathrm{H}), 4.28-4.13(\mathrm{~m}, 2 \mathrm{H}), 3.29$ (dd, $J=37.7,13.9 \mathrm{~Hz}, 2 \mathrm{H}), 2.86-2.78(\mathrm{~m}, 3 \mathrm{H}), 2.48(\mathrm{~s}, 3 \mathrm{H}), 2.44(\mathrm{~s}, 3 \mathrm{H}), 2.32-2.22(\mathrm{~m}, 4 \mathrm{H}), 1.99-1.95(\mathrm{~m}$, $1 \mathrm{H}), 1.71(\mathrm{td}, J=12.5,3.2 \mathrm{~Hz}, 1 \mathrm{H}), 1.43-1.34(\mathrm{~m}, 2 \mathrm{H}), 0.95-0.90(\mathrm{~m}, 5 \mathrm{H}), 0.17-0.71(\mathrm{~m}, 21 \mathrm{H}),-0.26--0.23$ $(\mathrm{m}, 15 \mathrm{H}) \mathrm{ppm}$;

${ }^{13} \mathrm{C}$ NMR $\left(101 \mathrm{MHz}, \mathrm{CDCl}_{3}\right) \delta 204.4,204.0,147.3,143.8,143.7,142.9,141.2,135.1,134.9,133.42,133.38,133.2$, $130.5,130.4,128.9,127.7,123.5,123.3,115.1,113.6,87.42,87.37,73.9,71.7,66.4,65.9,39.9,39.4,36.0,33.4$, $21.94,21.90,16.0,15.0,2.0,1.7,0.7,0.6,0.5 \mathrm{ppm}$;

HRMS (ESI) calcd. for $\mathrm{C}_{28} \mathrm{H}_{44} \mathrm{~N}_{3} \mathrm{O}_{5} \mathrm{SSi}_{2}[\mathrm{M}+\mathrm{H}]^{+}: 590.2540$, found: 590.2535 .

\section{Synthesis of compound 32}
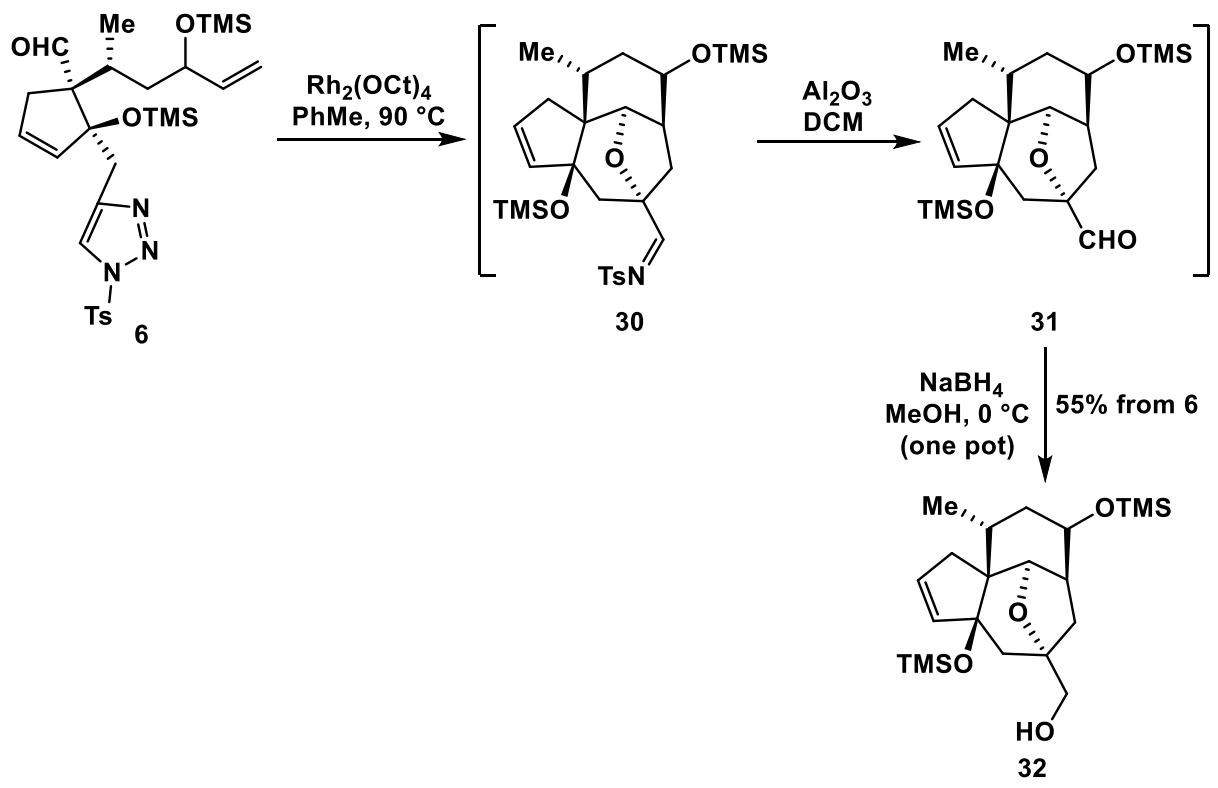
An oven-dried tube was charged with triazole 6 (700 mg, $1.2 \mathrm{mmol}, 1.0$ equiv.), $3 \AA \mathrm{MS}$ (225 mg), and $\mathrm{Rh}_{2}(\mathrm{OCt})_{4}$ (19 mg, $0.024 \mathrm{mmol}, 0.02$ equiv.). The tube was evacuated and backfilled with argon (repeated three times). Then, toluene $(12 \mathrm{~mL}, 0.1 \mathrm{M})$ was added into the reaction via syringe. The reaction mixture was stirring at $90{ }^{\circ} \mathrm{C}$ for $8 \mathrm{~h}$. The solution was then allowed to cool to $25{ }^{\circ} \mathrm{C}$, and DCM $(24 \mathrm{~mL})$ was added into the reaction, followed by basic alumina $(6 \mathrm{~g})$. The mixture was stirred for $1.5 \mathrm{~h}$, then was concentrated in vacuum, and $\mathrm{MeOH}(12 \mathrm{~mL})$ was added. The mixture was immediately cooled to $0{ }^{\circ} \mathrm{C}$. $\mathrm{NaBH}_{4}(91 \mathrm{mg}, 2.4 \mathrm{mmol} .2 .0$ equiv.) was added dropwise and the reaction mixture was stirred at $0{ }^{\circ} \mathrm{C}$ for $1.5 \mathrm{~h}$. The reaction was quenched with $\mathrm{H}_{2} \mathrm{O}(20 \mathrm{~mL})$ and extracted with DCM $(3 \times 20 \mathrm{~mL})$. The combined extracts were dried by $\mathrm{Na}_{2} \mathrm{SO}_{4}$, filtered, concentrated. The crude product was purified by a flash-column chromatography on silica gel (hexane/EtOAc, 4:1 1:1) to afford 32 (305 $\mathrm{mg}, 55 \%$ from $\mathbf{6})$ as a colorless oil.

$\boldsymbol{R}_{\boldsymbol{f}}=0.4$ (hexane: $\mathrm{EtOAc}=2: 1$ );

${ }^{1} \mathrm{H}$ NMR $\left(500 \mathrm{MHz}, \mathrm{CDCl}_{3}\right) \delta 5.81-5.56(\mathrm{~m}, 4 \mathrm{H}), 4.28-4.04(\mathrm{~m}, 4 \mathrm{H}), 3.65-3.43(\mathrm{~m}, 4 \mathrm{H}), 2.82-2.59(\mathrm{~m}, 2 \mathrm{H})$, $2.53-2.37(\mathrm{~m}, 4 \mathrm{H}), 2.35-2.24(\mathrm{~m}, 3 \mathrm{H}), 2.20-2.09(\mathrm{~m}, 3 \mathrm{H}), 2.04-1.93(\mathrm{~m}, 4 \mathrm{H}), 1.41-1.36(\mathrm{~m}, 1 \mathrm{H}), 0.96(\mathrm{~d}, J$ $=7.5 \mathrm{~Hz}, 1 \mathrm{H}), 0.92(\mathrm{~d}, J=7.3 \mathrm{~Hz}, 1 \mathrm{H}), 0.23-0.15(\mathrm{~m}, 12 \mathrm{H}), 0.14-0.11(\mathrm{~m}, 24 \mathrm{H}) \mathrm{ppm}$;

${ }^{13}$ C NMR $\left(125 \mathrm{MHz}, \mathrm{CDCl}_{3}\right) \delta 139.0,137.3,129.5,128.3,85.2,84.1,82.9,80.0,79.9,72.2,67.90,67.88,65.5$, 51.3, 49.7, 49.2, 47.5, 47.4, 46.0, 45.7, 38.8, 37.3, 35.0, 34.2, 32.0, 31.7, 27.7, 21.0, 17.7, 2.5, 2.4, 0.5, 0.4 ppm;

HRMS (ESI) calcd. for $\mathrm{C}_{21} \mathrm{H}_{38} \mathrm{O}_{4} \mathrm{NaSi}_{2}[\mathrm{M}+\mathrm{Na}]^{+}$: 433.2201, found: 433.2196 .

\section{Synthesis of compound 33}

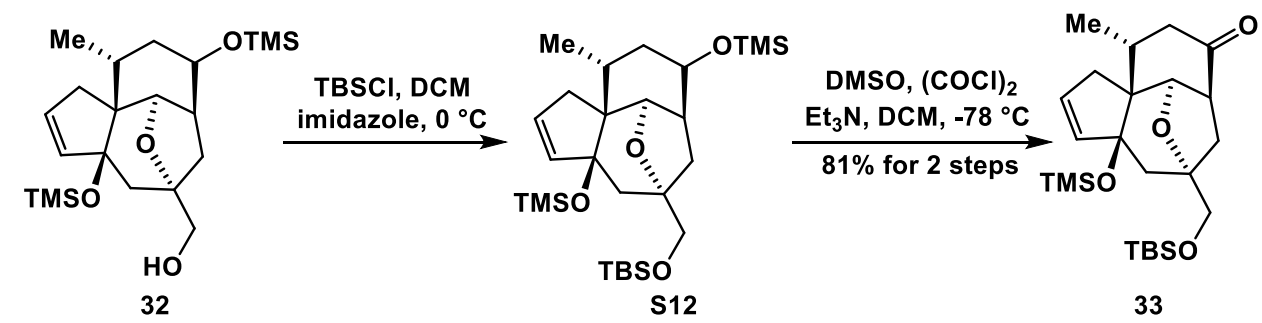

To a solution of alcohol 32 (205 mg, $0.5 \mathrm{mmol}, 1.0$ equiv.) in DCM (5 mL, $0.1 \mathrm{M})$ was added imidazole (102 mg, $1.5 \mathrm{mmol}, 3.0$ equiv.) and $\operatorname{TBSCl}(151 \mathrm{mg}, 1.0 \mathrm{mmol}, 2.0$ equiv. $)$ at $0{ }^{\circ} \mathrm{C}$. The reaction mixture was stirred for 3 hours, and TLC showed the consumption of the starting material. The reaction mixture was quenched by saturated aqueous $\mathrm{NaHCO}_{3}(5 \mathrm{~mL})$. The mixture was extracted with DCM $(3 \times 5 \mathrm{~mL})$. The combined organic layers were dried over $\mathrm{Na}_{2} \mathrm{SO}_{4}$, filtered, and concentrated under reduced pressure. The crude product was used for the next step without further purification.

Oxalyl dichloride $(0.05 \mathrm{~mL}, 74 \mathrm{mg}, 0.58 \mathrm{mmol}, 1.16$ equiv. $)$ was stirred in dry $\mathrm{DCM}(5 \mathrm{~mL}, 0.1 \mathrm{M})$ at $-78^{\circ} \mathrm{C}$ under nitrogen. A solution of dimethyl sulfoxide $(0.1 \mathrm{~mL}, 110 \mathrm{mg}, 1.4 \mathrm{mmol}, 2.8$ equiv. $)$ in dry DCM was added dropwise over a period of $15 \mathrm{~min}$, keeping the internal temperature below $-60{ }^{\circ} \mathrm{C}$. The mixture was stirred for 5 min, then a solution of $\mathbf{S 1 2}$ in dry DCM $(2 \mathrm{~mL})$ was added dropwise over a period of $15 \mathrm{~min}$. After stirring of the mixture at $78{ }^{\circ} \mathrm{C}$ for $2 \mathrm{~h}, \mathrm{Et}_{3} \mathrm{~N}(0.5 \mathrm{~mL})$ was added over a period of $5 \mathrm{~min}$ and the mixture was stirred at $-78{ }^{\circ} \mathrm{C}$ for a further 30 min, then allowed to warm to $25^{\circ} \mathrm{C}$. Water $(2 \mathrm{~mL})$ and DCM $(2 \mathrm{~mL})$ were successively added and the mixture was 
stirred for $25 \mathrm{~min}$. The mixture was extracted with DCM $(3 \times 10 \mathrm{~mL})$ and the combined organic layers were dried over $\mathrm{Na}_{2} \mathrm{SO}_{4}$, filtered and concentrated under reduced pressure. Purification of the crude product by flash-column chromatography on silica gel (hexane/Et $2 \mathrm{O}, 2: 1)$ afford $\mathbf{3 3}$ (182 $\mathrm{mg}, 81 \%$ for 2 steps) as a colorless oil.

$\boldsymbol{R}_{\boldsymbol{f}}=0.30$ (hexane: $\mathrm{Et}_{2} \mathrm{O}=2: 1$ );

IR (film) $\lambda \max 2953,1730,1249,840 \mathrm{~cm}^{-1}$;

${ }^{1} \mathbf{H}$ NMR $\left(500 \mathrm{MHz}, \mathrm{CDCl}_{3}\right) \delta 5.73(\mathrm{ddd}, J=27.1,6.1,2.8 \mathrm{~Hz}, 2 \mathrm{H}), 4.42(\mathrm{~d}, J=7.8 \mathrm{~Hz}, 1 \mathrm{H}), 3.57-3.50(\mathrm{~m}, 2 \mathrm{H})$, $2.99(\mathrm{ddd}, J=12.8,7.9,4.7 \mathrm{~Hz}, 1 \mathrm{H}), 2.79(\mathrm{dd}, J=16.2,8.0 \mathrm{~Hz}, 1 \mathrm{H}), 2.58(\mathrm{dt}, J=16.4,2.4 \mathrm{~Hz}, 1 \mathrm{H}), 2.48(\mathrm{dd}, J=$ 16.6, 3.1 Hz, 1H), 2.35 (dt, $J=14.7,7.4 \mathrm{~Hz}, 1 \mathrm{H}), 2.21-2.09$ (m, 2H), $1.91-1.75(\mathrm{~m}, 3 \mathrm{H}), 1.00-0.94(\mathrm{~m}, 3 \mathrm{H})$, 0.88 (s, 9H), 0.12 (s, 9H), 0.04 (s, 6H) ppm;

${ }^{13} \mathrm{C}$ NMR $\left(125 \mathrm{MHz}, \mathrm{CDCl}_{3}\right) \delta 211.8,137.4,128.4,85.6,80.0,77.5,68.6,51.5,50.4,46.5,46.0,37.5,35.8,29.2$, 26.0, 20.5, 18.4, 2.1, -5.23, -5.24 ppm;

HRMS (ESI) calcd. for $\mathrm{C}_{24} \mathrm{H}_{43} \mathrm{O}_{4} \mathrm{Si}_{2}[\mathrm{M}+\mathrm{H}]^{+}: 451.2694$, found: 451.2684 .

\section{Synthesis of compound 34}

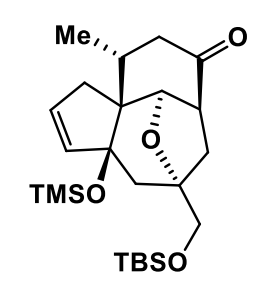

33

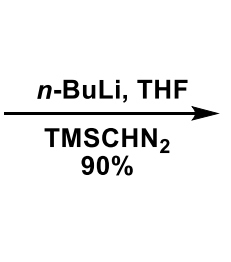

TMSCHN
$90 \%$

$34 a$
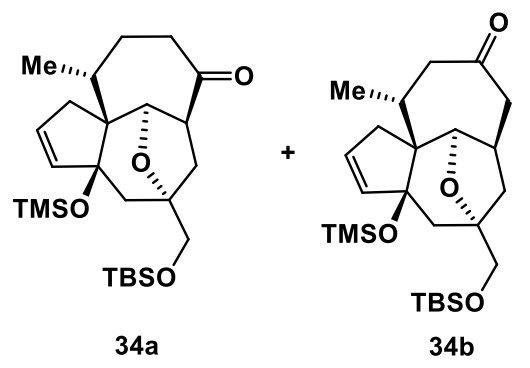

$n$-BuLi (2.5M solution in hexanes, $67.0 \mu \mathrm{L}, 0.168 \mathrm{mmol}, 1.5$ equiv.) was added to $\mathrm{THF}(2 \mathrm{~mL}, 0.056 \mathrm{M})$ at $-78^{\circ} \mathrm{C}$, followed by the addition of $\mathrm{TMSCHN}_{2}(2.0 \mathrm{M}$ solution in hexanes, $84 \mu \mathrm{L}, 0.168 \mathrm{mmol}, 1.5$ equiv.). The mixture was stirred for 15 minutes, before ketone 33 (50 mg, $0.111 \mathrm{~mol}, 1.0$ equiv.) was added in THF $(4.0 \mathrm{~mL})$. The reaction mixture was stirred for 45 minutes at $-78{ }^{\circ} \mathrm{C}$, before the addition of $\mathrm{MeOH}(1 \mathrm{~mL} \mathrm{MeOH}$ in $1 \mathrm{~mL} \mathrm{THF})$ at $-78{ }^{\circ} \mathrm{C}$ quenched the reaction. The reaction mixture was diluted with EtOAc $(2 \mathrm{~mL})$ and $1 \mathrm{M} \mathrm{NaOH}(2 \mathrm{~mL})$. The layers were separated, and the aqueous layer was extracted with EtOAc $(3 \times 5 \mathrm{~mL})$. The combined organic layers were dried over $\mathrm{MgSO}_{4}$ and silica gel (2.0 g) was added to the solution. The mixture was stirred for 30 minutes and the solvent was removed under reduced pressure. The remains were redissolved in EtOAc. The organic layer was extracted three times with $1 \mathrm{M} \mathrm{HCl}$ solution. The organic phase containing the non-aminic remains was then discarded. The acidic phase was then adjusted to basic $\mathrm{pH}$ with $2 \mathrm{M} \mathrm{NaOH}$ solution $(2 \mathrm{~mL})$ was added. The basic phase was extracted three times with EtOAc $(3 \times 5 \mathrm{~mL})$. The combined organic layers were dried over $\mathrm{MgSO}_{4}$ and the solvent was removed under reduced pressure. Purification of the crude product by flash-column chromatography on silica gel (hexane/Et ${ }_{2} \mathrm{O}$, 4:1) to afford $\mathbf{3 4}$ as a pair of inseparable diastereomers ( $47 \mathrm{mg}, 90 \%, \mathbf{3 4 a}: \mathbf{3 4 b}=1: 1)$ as a colorless oil.

$\boldsymbol{R}_{\boldsymbol{f}}=0.3$ (hexane: EtOAc $=4: 1$ );

IR (film) $\lambda \max 2954,1714,1249,840 \mathrm{~cm}^{-1}$; 
${ }^{1} \mathbf{H}$ NMR $\left(500 \mathrm{MHz}, \mathrm{CDCl}_{3}\right) \delta 5.80(\mathrm{dd}, J=6.0,2.6 \mathrm{~Hz}, 1 \mathrm{H}), 5.74(\mathrm{dd}, J=6.0,2.6 \mathrm{~Hz}, 1 \mathrm{H}), 5.67-5.62(\mathrm{~m}, 1 \mathrm{H})$, $5.60(\mathrm{ddd}, J=7.5,3.4,1.8 \mathrm{~Hz}, 1 \mathrm{H}), 4.60(\mathrm{~d}, J=6.9 \mathrm{~Hz}, 1 \mathrm{H}), 3.94(\mathrm{~d}, J=6.1 \mathrm{~Hz}, 1 \mathrm{H}), 3.52-3.45(\mathrm{~m}, 4 \mathrm{H}), 3.12-$ 3.07 (m, 2H), 2.72 (ddd, $J=13.5,8.7,5.0 \mathrm{~Hz}, 1 \mathrm{H}), 2.54-2.37(\mathrm{~m}, 6 \mathrm{H}), 2.36-2.27(\mathrm{~m}, 4 \mathrm{H}), 2.10-2.03(\mathrm{~m}, 3 \mathrm{H})$, $2.01-1.93(\mathrm{~m}, 3 \mathrm{H}), 1.88-1.75(\mathrm{~m}, 2 \mathrm{H}), 1.70-1.62(\mathrm{~m}, 3 \mathrm{H}), 0.93-0.89(\mathrm{~m}, 6 \mathrm{H}), 0.88(\mathrm{~s}, 18 \mathrm{H}), 0.19(\mathrm{~s}, 9 \mathrm{H})$, $0.14(\mathrm{~s}, 9 \mathrm{H}), 0.06-0.03(\mathrm{~m}, 12 \mathrm{H}) \mathrm{ppm}$;

${ }^{13}$ C NMR $\left(125 \mathrm{MHz}, \mathrm{CDCl}_{3}\right) \delta 212.5,208.8,138.0,137.9,129.1,128.3,84.6,84.5,81.3,79.8,78.1,68.9,57.1$, 55.4, 54.1, 49.9, 49.0, 46.7, 43.3, 41.1, 38.8, 37.8, 37.4, 35.7, 31.7, 29.8, 28.4, 26.0, 26.0, 25.7, 19.6, 18.56, 18.4, $2.2,2.2,1.2,-5.17,-5.21,-5.25,-5.26 \mathrm{ppm}$;

HRMS (ESI) calcd. for $\mathrm{C}_{25} \mathrm{H}_{44} \mathrm{O}_{4} \mathrm{NaSi}_{2}[\mathrm{M}+\mathrm{Na}]^{+}: 487.2670$, found: 487.2662 .

Note: We synthesized compounds $34 \mathbf{a}$ and $\mathbf{3 4} \mathbf{b}$ with poor regioselectivity as a pair of inseparable isomers. For this reason, the conversion of 34a to an anti-Bredt silyl enol ether had not done. Development an efficient route to construction of the desired tricyclic core is underway and will be reported in the future. 


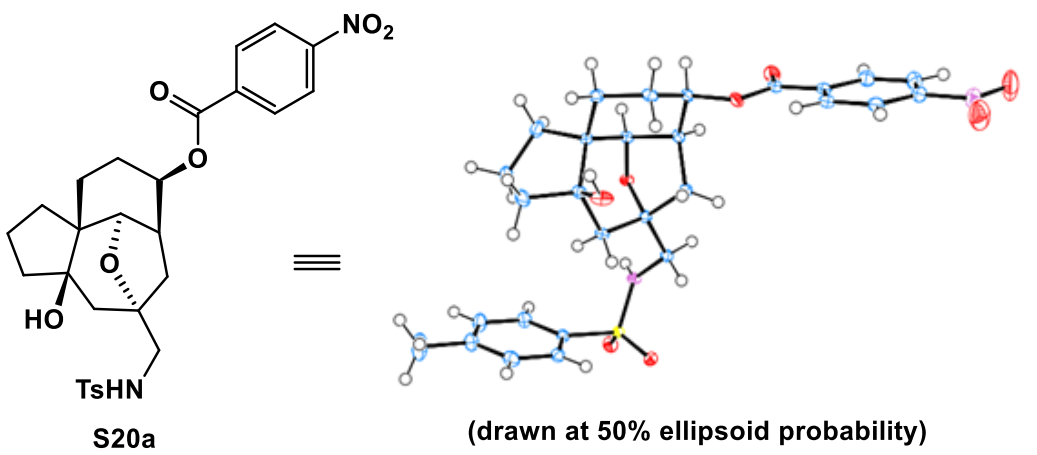

A colorless block shaped crystal of S20a for X-ray diffraction was obtained by slow evaporation from DCM. The Xray intensity data were measured at $100 \mathrm{~K}$ on a Bruker APEX-II CCD diffractometer with Mo K $\alpha$ radiation $(\lambda=$ $0.71073 \AA$ A). Crystal data and structure refinement for S20a.

\begin{tabular}{|c|c|}
\hline CCDC & 1920647 \\
\hline Empirical formula & $\mathrm{C}_{28} \mathrm{H}_{32} \mathrm{~N}_{2} \mathrm{O}_{8} \mathrm{~S}$ \\
\hline Formula weight & 556.61 \\
\hline Temperature/K & 100 \\
\hline Crystal system & triclinic \\
\hline Space group & $\mathrm{P}-1$ \\
\hline $\mathrm{a} / \AA$ & $6.450(3)$ \\
\hline $\mathrm{b} / \AA$ & $13.539(8)$ \\
\hline $\mathrm{c} / \AA$ & $15.744(9)$ \\
\hline$\alpha /^{\circ}$ & $92.595(19)$ \\
\hline$\beta /{ }^{\circ}$ & $100.795(16)$ \\
\hline$\gamma /{ }^{\circ}$ & $100.283(17)$ \\
\hline Volume/Å3 & $1324.5(13)$ \\
\hline $\mathrm{Z}$ & 2 \\
\hline$\rho c a l c g / c m 3$ & 1.396 \\
\hline$\mu / \mathrm{mm}-1$ & 0.177 \\
\hline $\mathrm{F}(000)$ & 588.0 \\
\hline Crystal size/mm3 & $0.42 \times 0.38 \times 0.29$ \\
\hline Radiation & $\operatorname{MoK} \alpha(\lambda=0.71073)$ \\
\hline $2 \Theta$ range for data collection $/{ }^{\circ}$ & 4.208 to 55.066 \\
\hline Index ranges & $-8 \leq \mathrm{h} \leq 8,-17 \leq \mathrm{k} \leq 17,-20 \leq 1 \leq 20$ \\
\hline Reflections collected & 25683 \\
\hline Independent reflections & $6095[$ Rint $=0.0525$, Rsigma $=0.0430]$ \\
\hline Data/restraints/parameters & $6095 / 0 / 359$ \\
\hline Goodness-of-fit on F2 & 1.017 \\
\hline Final R indexes $[\mathrm{I}>=2 \sigma(\mathrm{I})]$ & $\mathrm{R} 1=0.0382, w \mathrm{R} 2=0.0905$ \\
\hline Final R indexes [all data] & $\mathrm{R} 1=0.0526, \mathrm{wR} 2=0.0967$ \\
\hline Largest diff. peak/hole / e $\AA-3$ & $0.35 /-0.38$ \\
\hline
\end{tabular}




\section{References}

1. Ojima, D.; Yasui, A.; Tohyama, K.; Tokuzumi, K.; Toriihara, E.; Ito, K.; Iwasaki, A.; Tomura, T.; Ojika, M.; Suenaga, K.Total synthesis of miuraenamides A and D. J. Org. Chem. 2016, 81, 9886-9894.

2. Liu, H. Q.; Sun, C. R.; Lee, N. K.; Henry, R. F.; Lee, D. New methylene homologation method for cyclic ketones. Chem. Eur. J. 2012, 18, 11889-11893.

3. Lathrop,S. P.; Rovis,T. Asymmetric synthesis of functionalized cyclopentanones via a multicatalytic secondary amine/N-heterocyclic carbene catalyzed cascade sequence. J. Am. Chem. Soc. 2009, 131, 13628-13630. 
5. ${ }^{1} \mathrm{H},{ }^{13} \mathrm{C}$ NMR and 2D-NMR Spectra
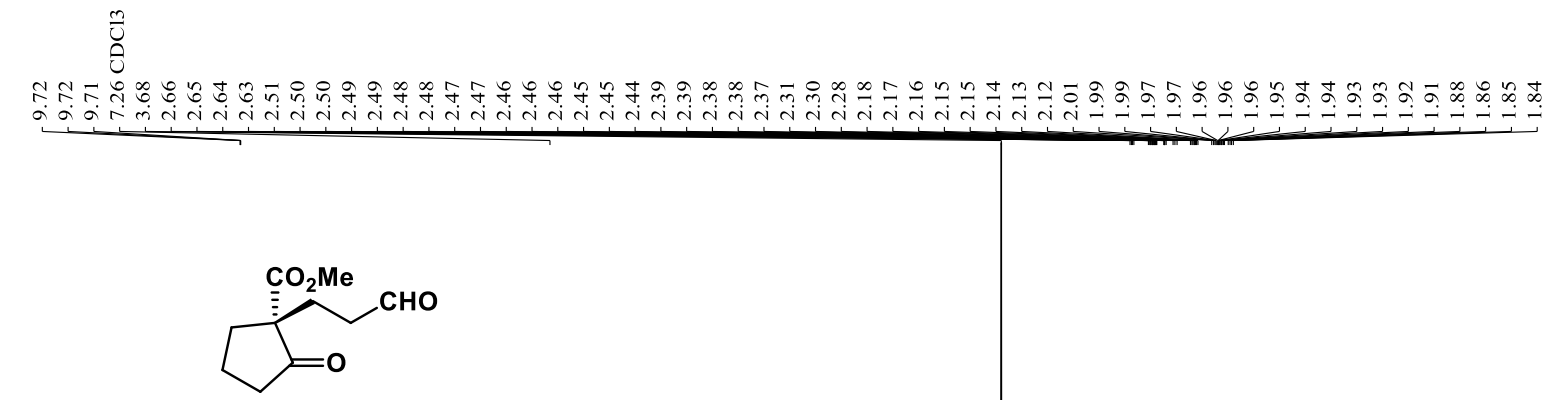

('H-NMR, $\mathrm{CDCl}_{3}, 500 \mathrm{MHz}$ )
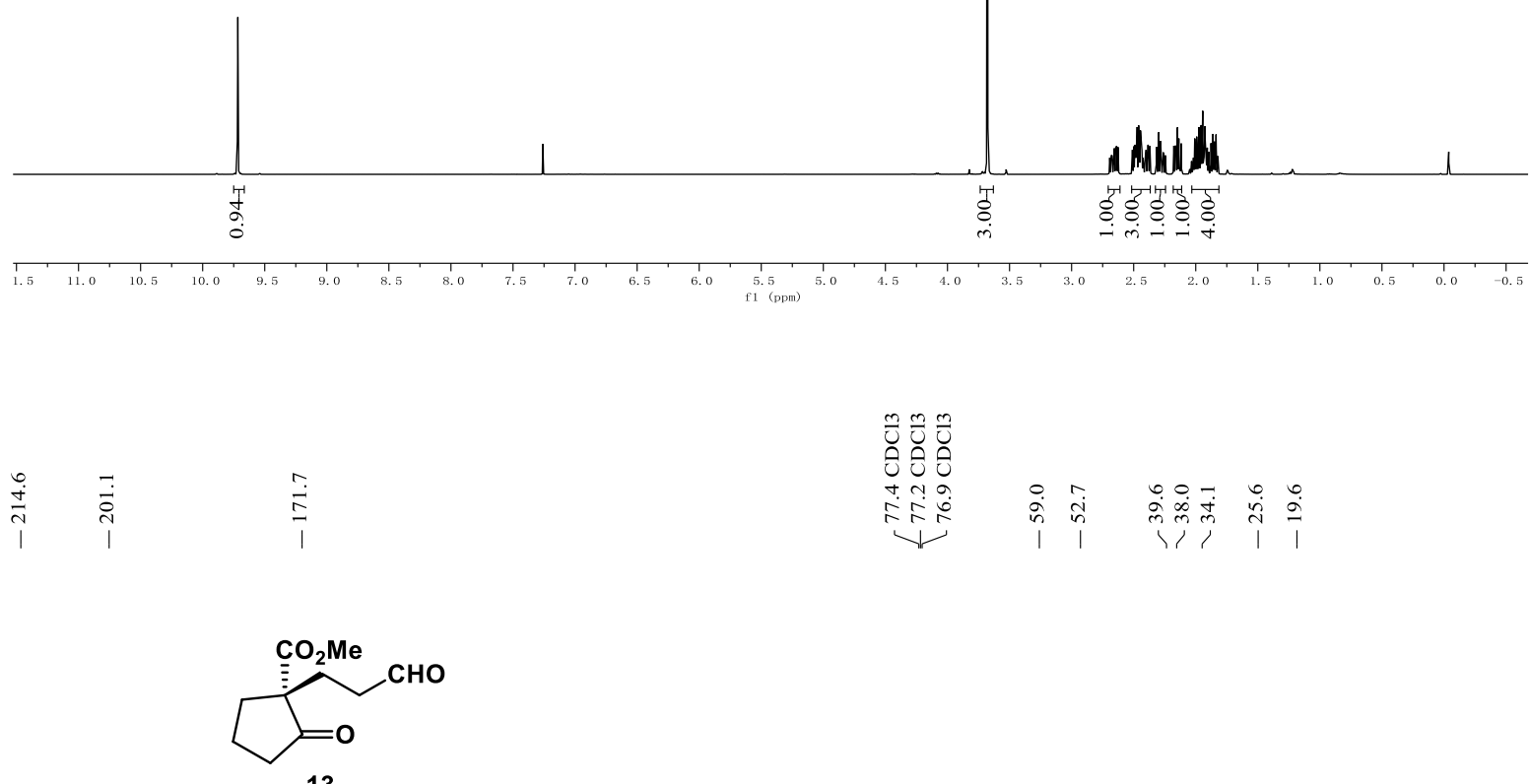

$\left({ }^{13} \mathrm{C}-\mathrm{NMR}, \mathrm{CDCl}_{3}, 125 \mathrm{MHz}\right)$

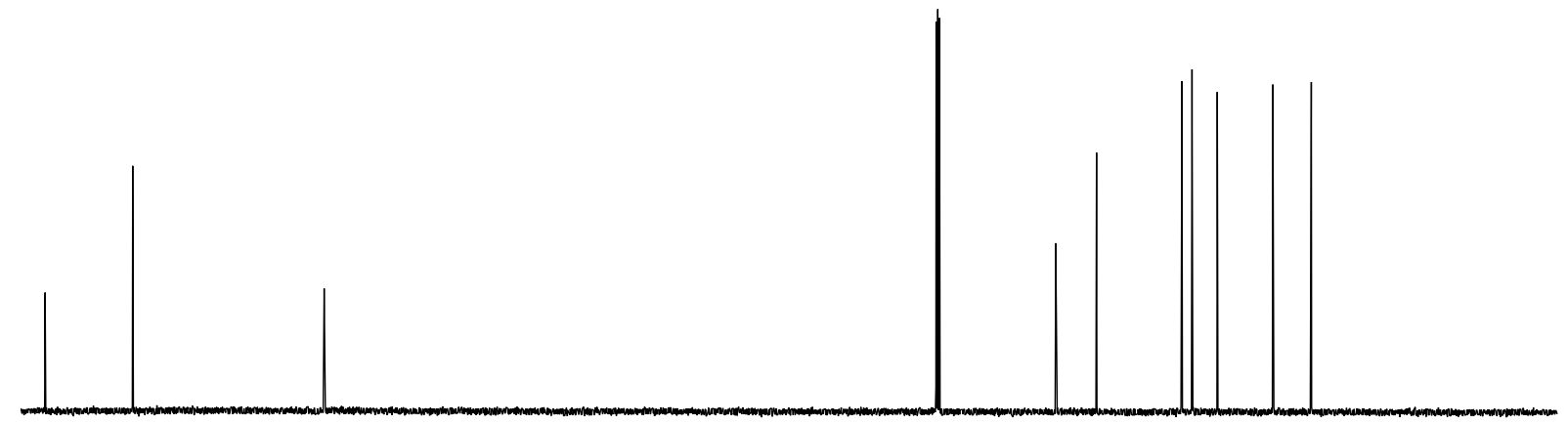




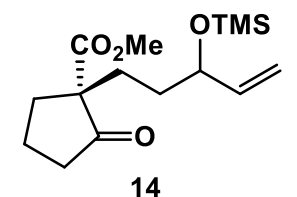

('H-NMR, $\mathrm{CDCl}_{3}, 500 \mathrm{MHz}$ )
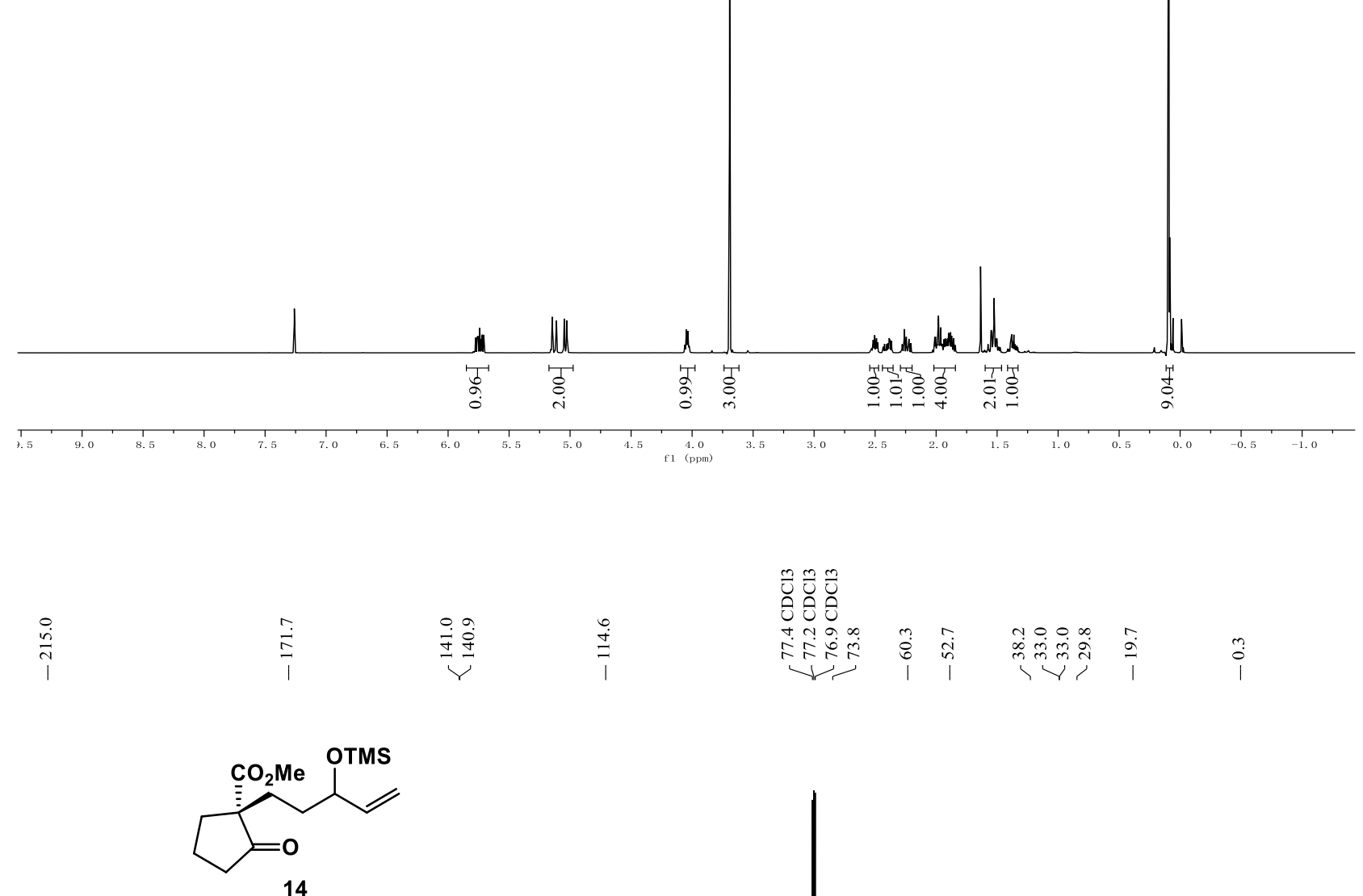

$\left({ }^{13} \mathrm{C}\right.$-NMR, $\left.\mathrm{CDCl}_{3}, 125 \mathrm{MHz}\right)$

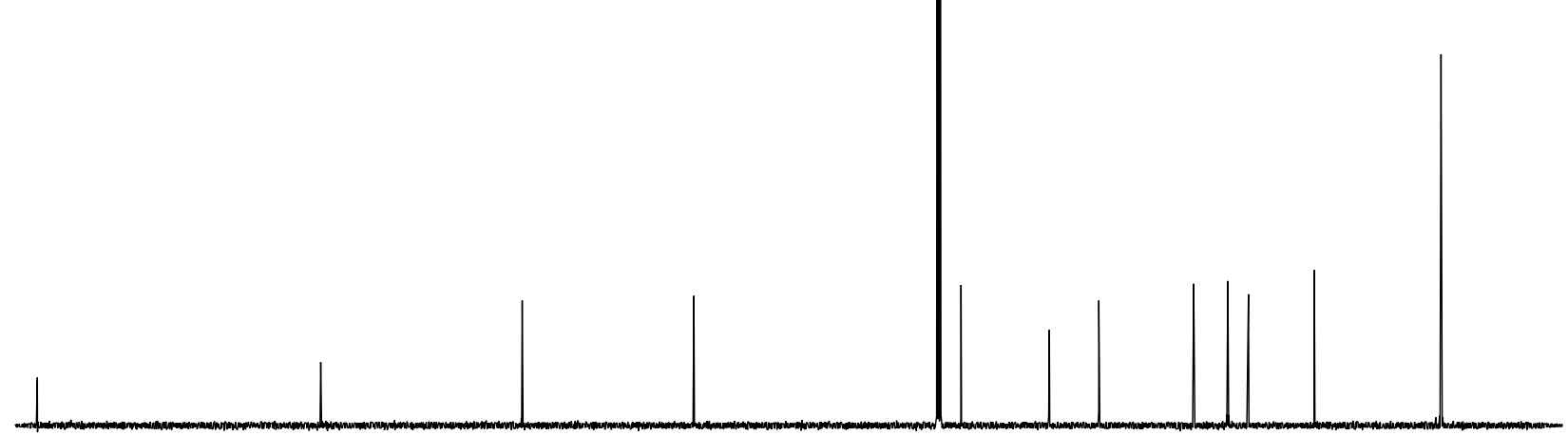


总

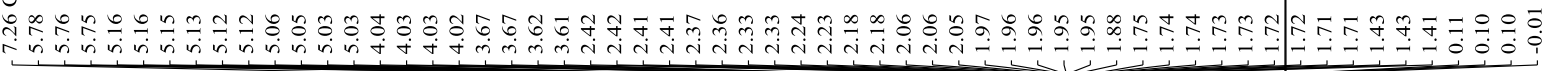

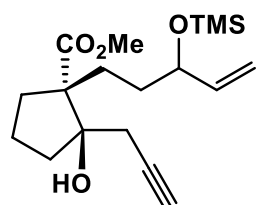

s2

( $\left.{ }^{1} \mathrm{H}-\mathrm{NMR}, \mathrm{CDCl}_{3}, 500 \mathrm{MHz}\right)$

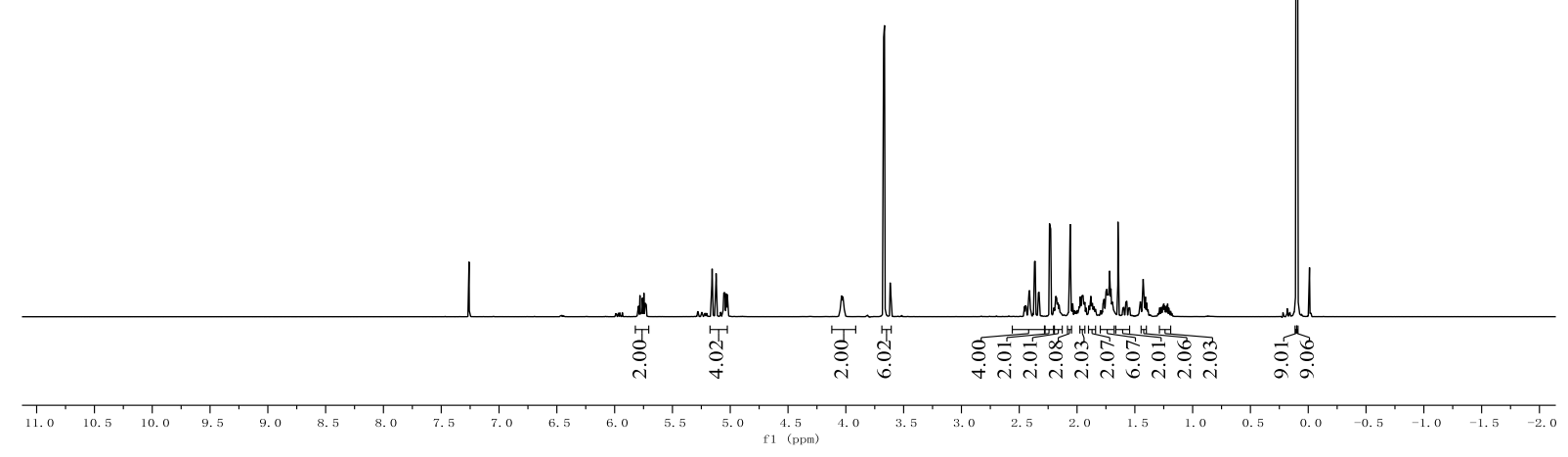

20180131-b2o-bq-sp. 2. fid

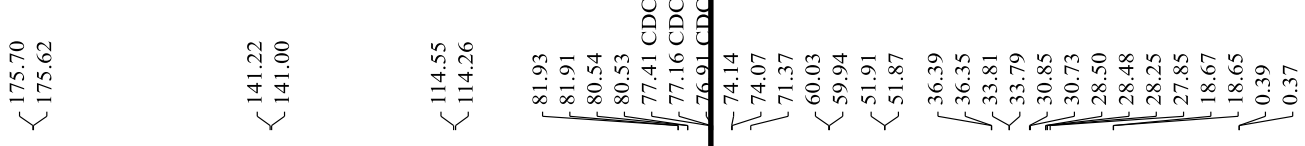

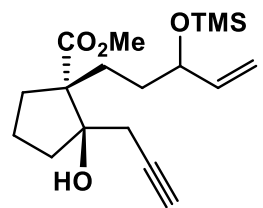

S2

$\left({ }^{13} \mathrm{C}-\mathrm{NMR}, \mathrm{CDCl}_{3}, 125 \mathrm{MHz}\right)$ 

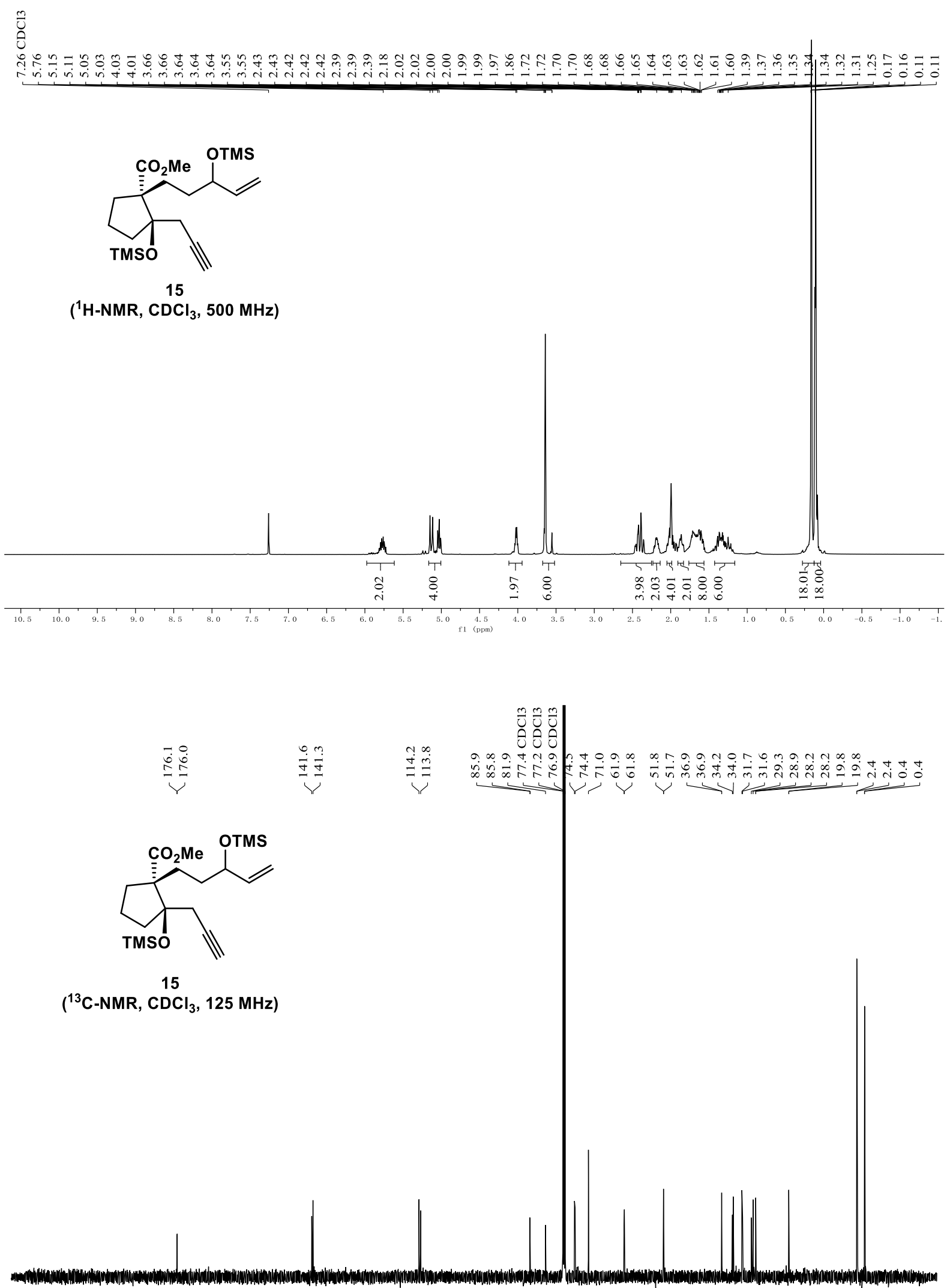

$\left({ }^{13} \mathrm{C}-\mathrm{NMR}, \mathrm{CDCl}_{3}, 125 \mathrm{MHz}\right)$ 

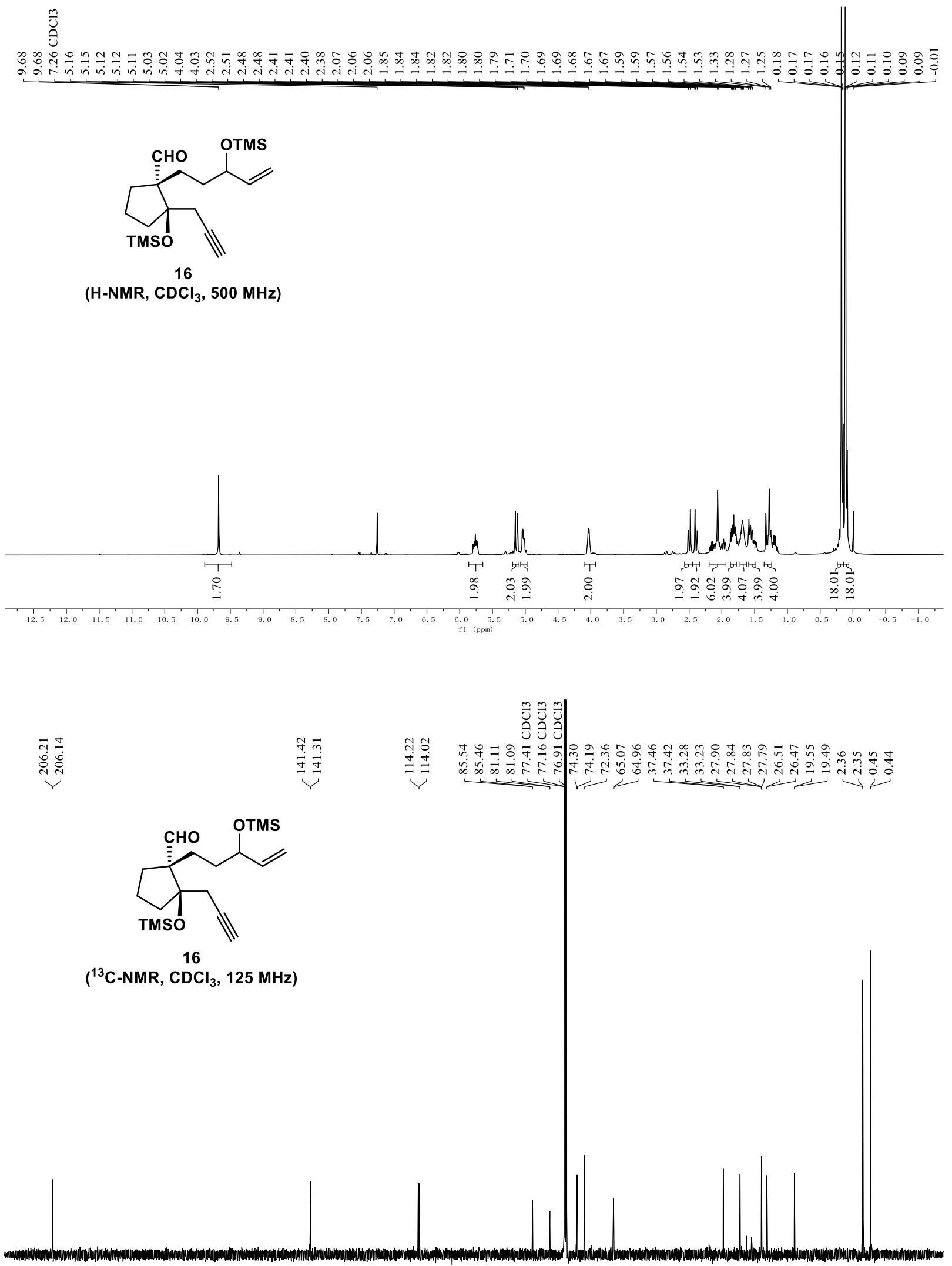


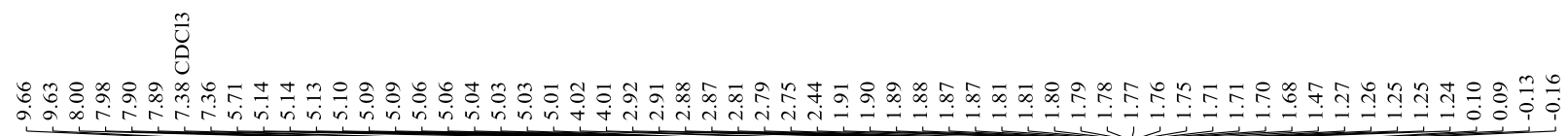

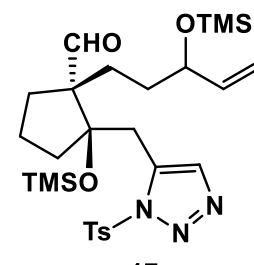

( ${ }^{1} \mathrm{H}-\mathrm{NMR}, \mathrm{CDCl}_{3}, 500 \mathrm{MHz}$ )

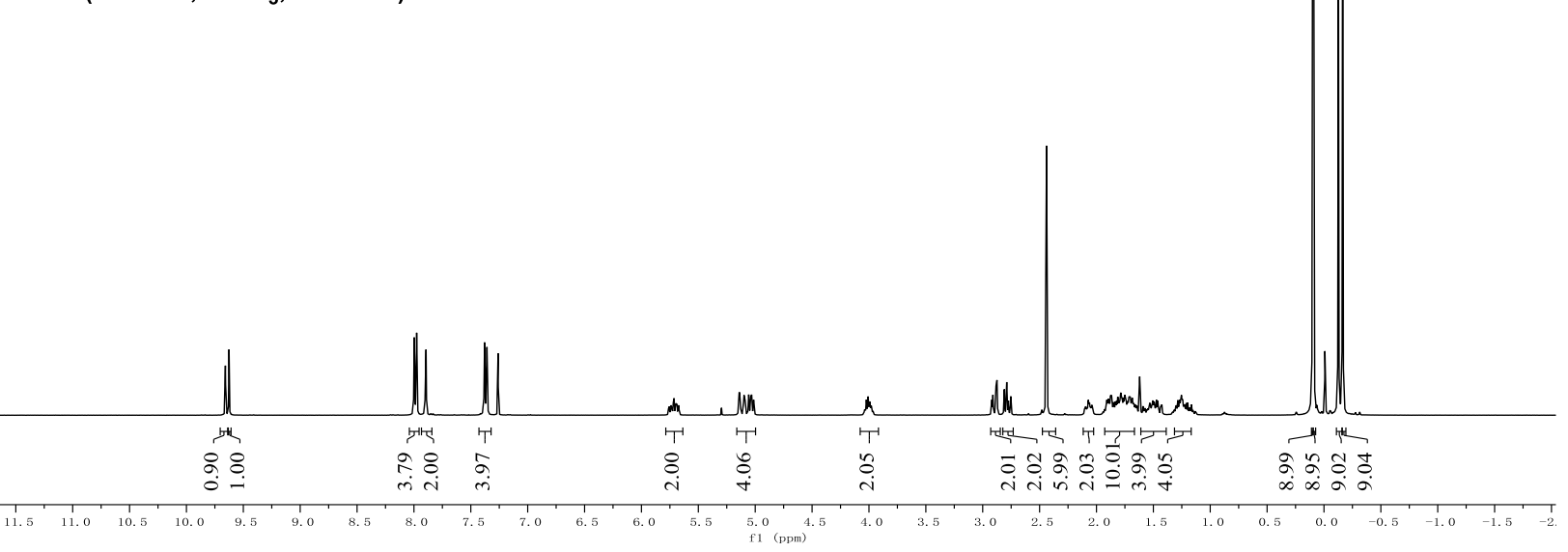

$\sqrt{3}$

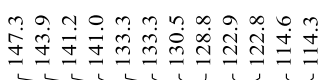

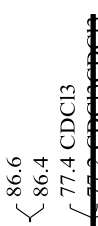

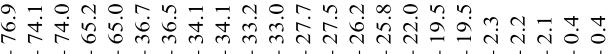

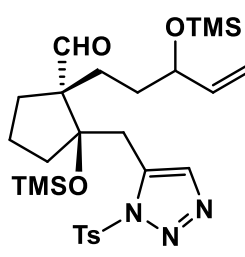

$\left({ }^{13} \mathrm{C}-\mathrm{NMR}, \mathrm{CDCl}_{3}, 125 \mathrm{MHz}\right)$

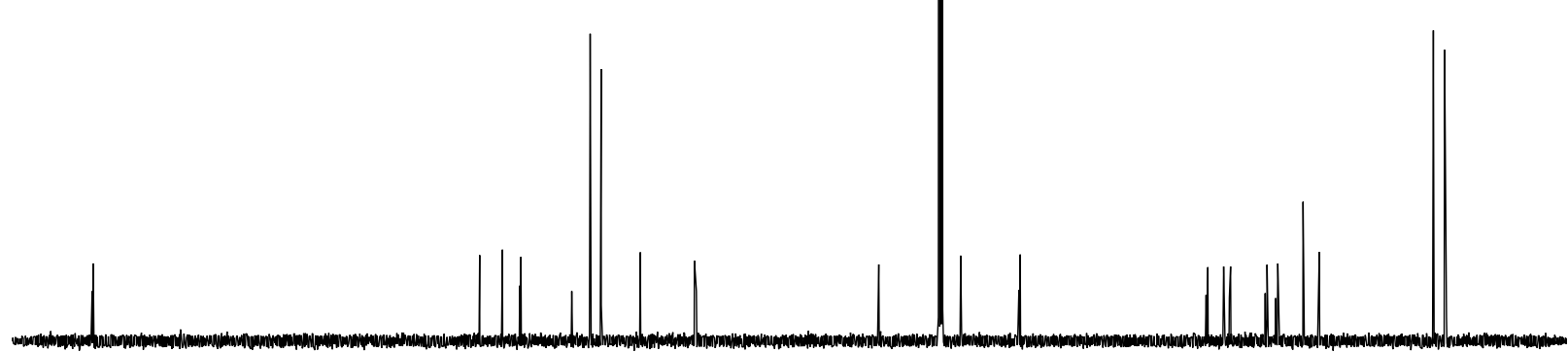




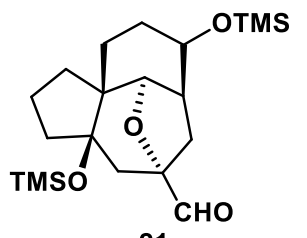

21

( ${ }^{1} \mathrm{H}-\mathrm{NMR}, \mathrm{CDCl}_{3}, 500 \mathrm{MHz}$ )
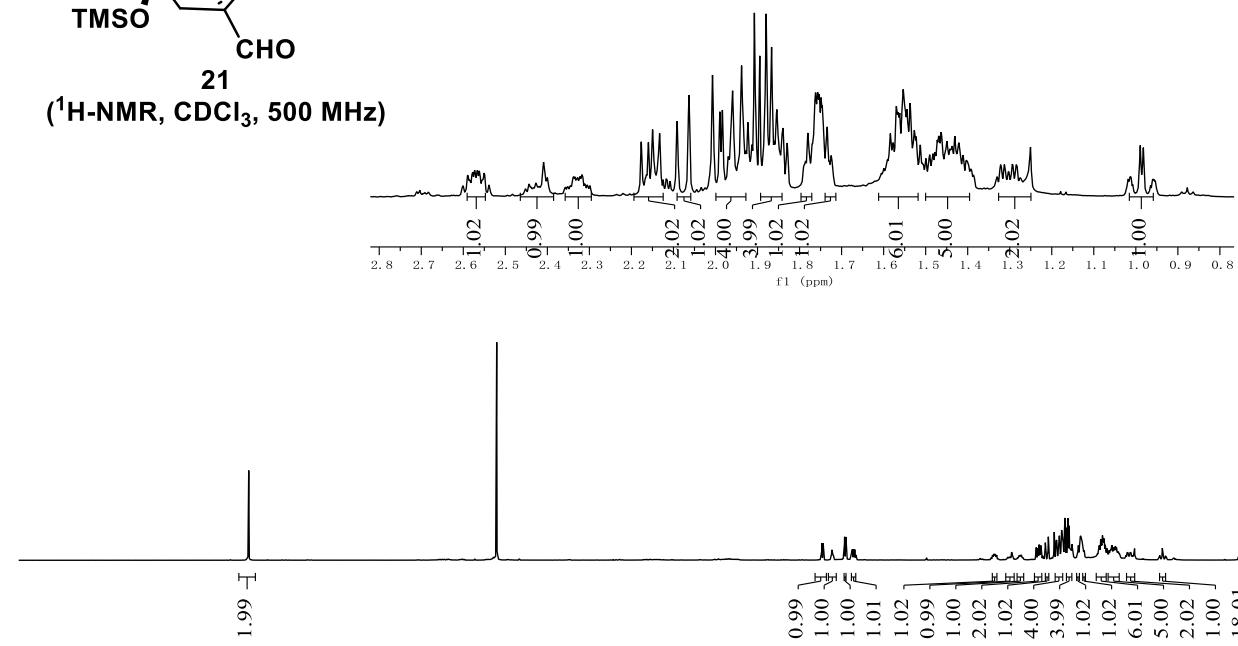

Whame

wh

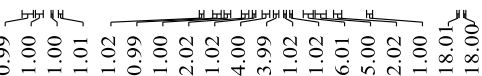

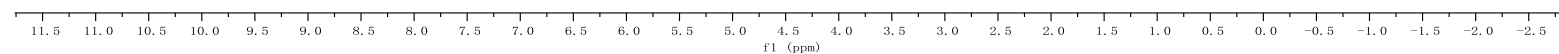

20171227-b2o-Rh-bz. 1. fid



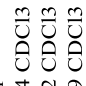

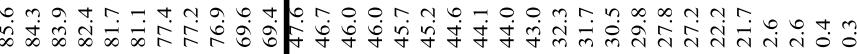

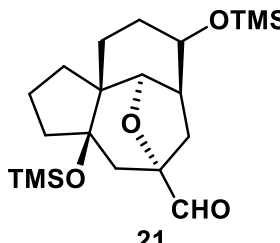

$\left({ }^{13} \mathrm{C}\right.$-NMR, $\mathrm{CDCl}_{3}, 125 \mathrm{MHz}$ )
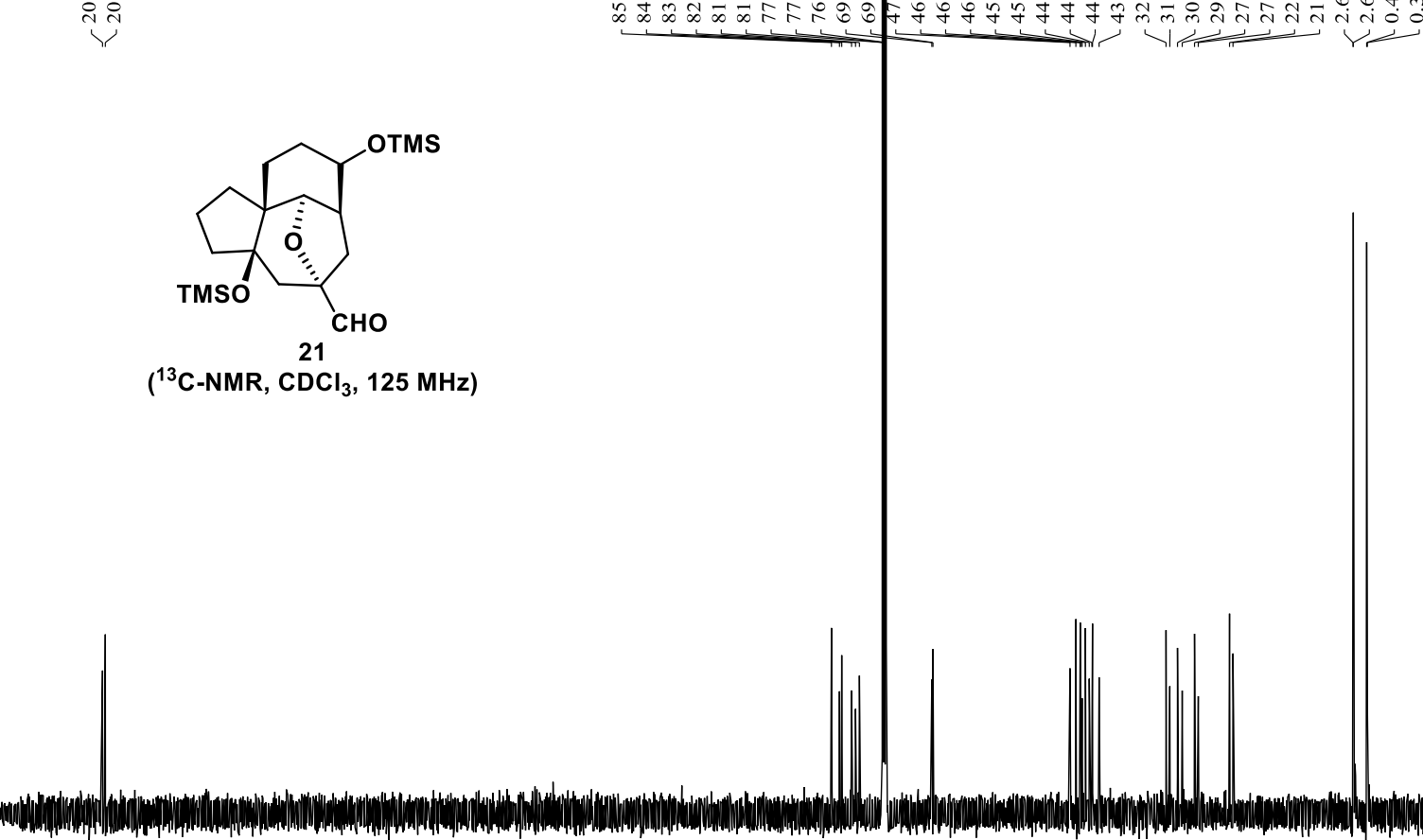

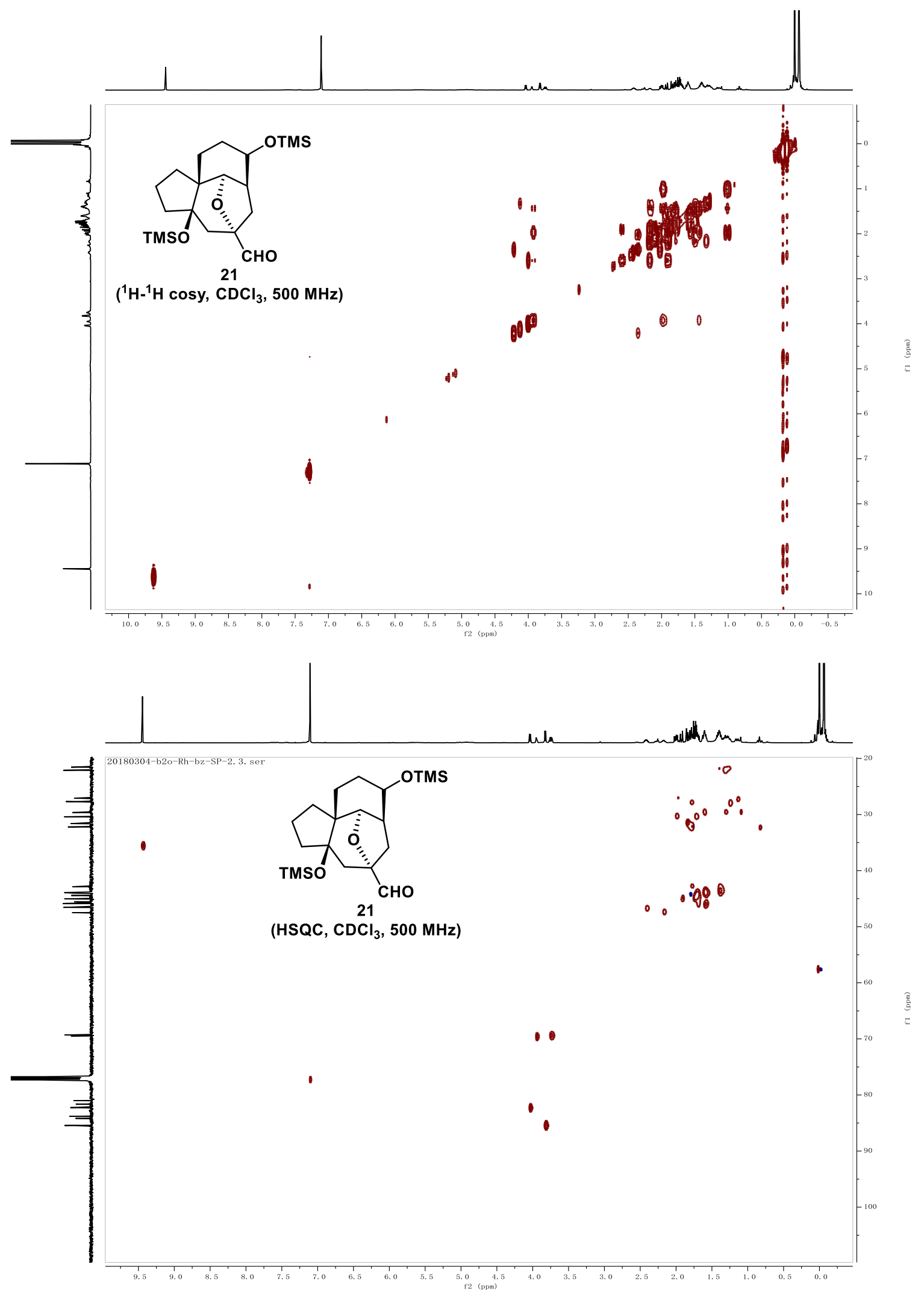

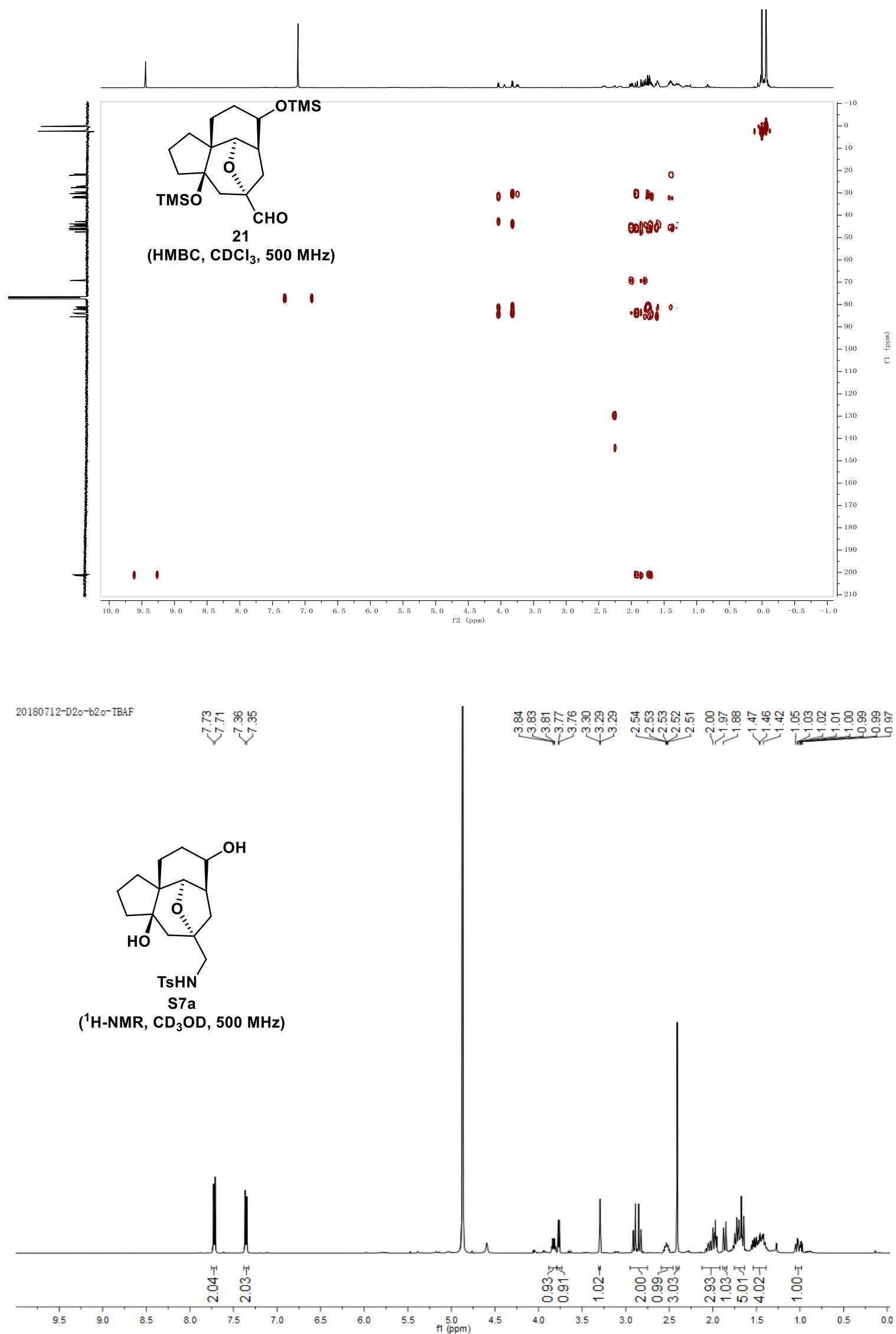


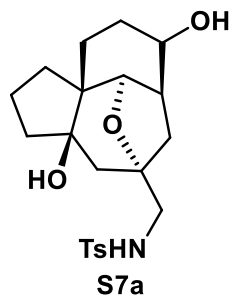

$\left({ }^{13} \mathrm{C}-\mathrm{NMR}, \mathrm{CD}_{3} \mathrm{OD}, 125 \mathrm{MHz}\right)$
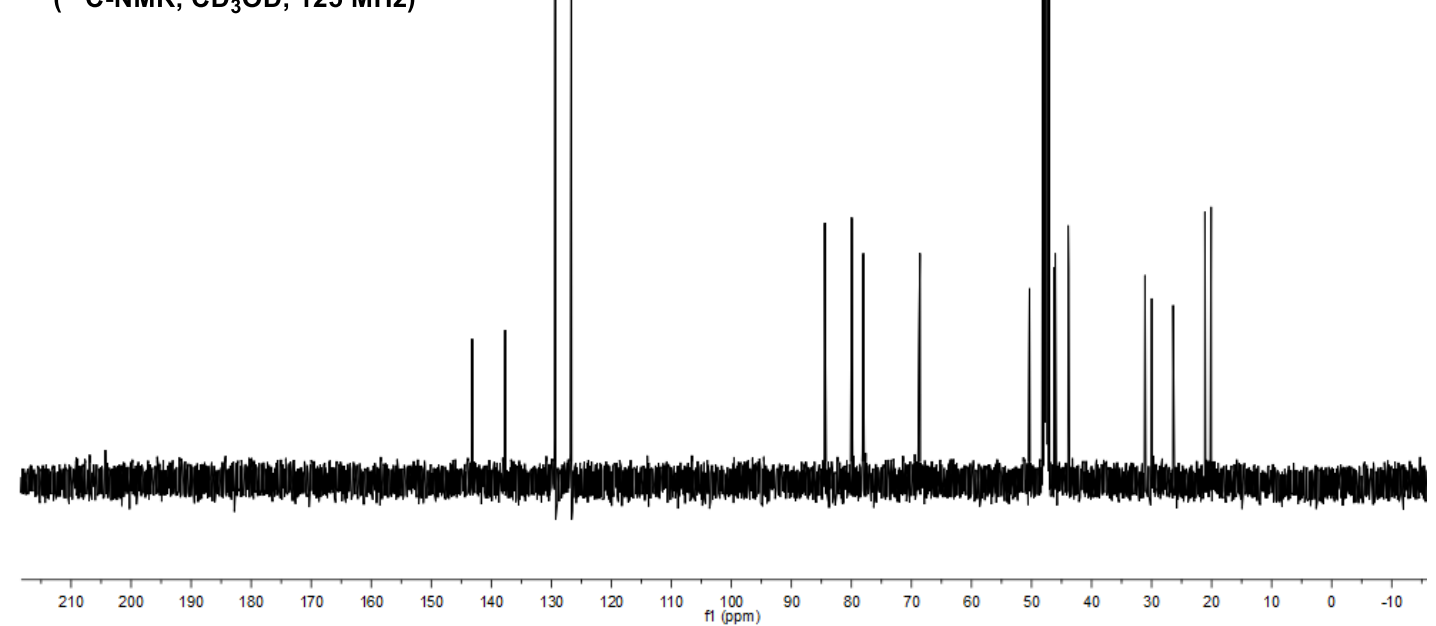

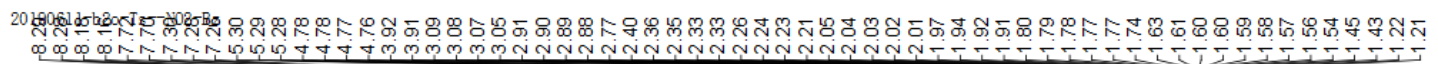<smiles>O=C(OC1CCC2(CCCC2(O)O)CC1(O)C[18O])c1ccc([N+](=O)[O-])cc1</smiles>

(H-NMR, $\left.\mathrm{CDCl}_{3}, 500 \mathrm{MHz}\right)$

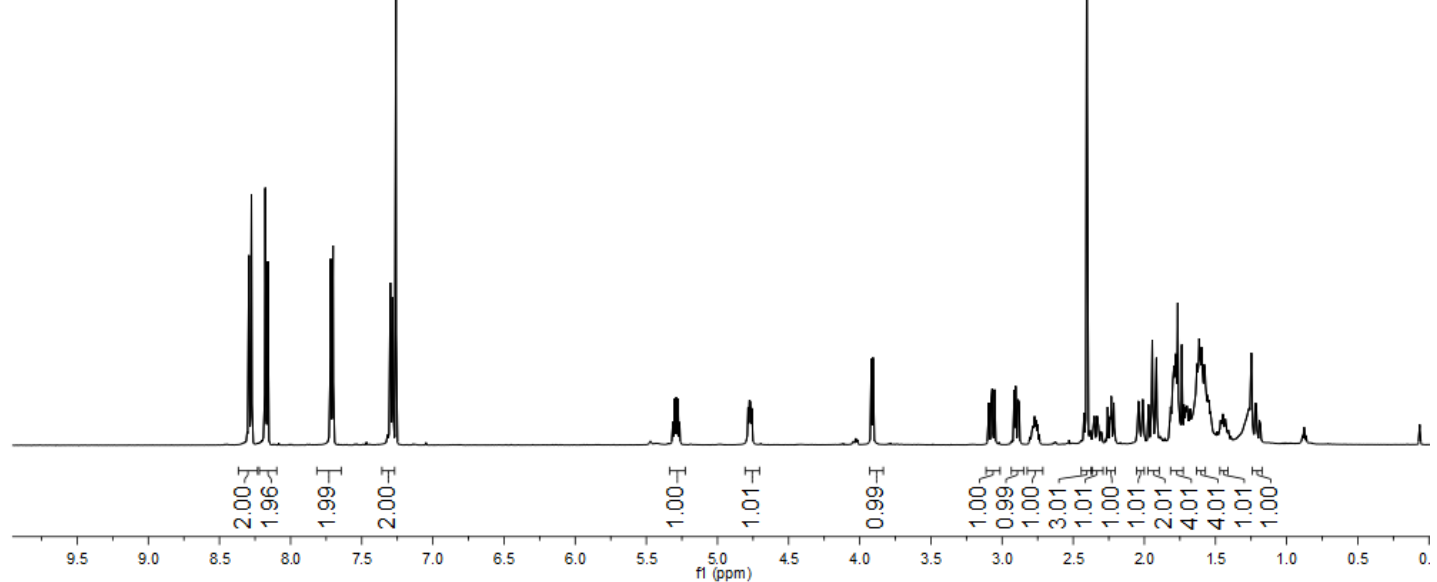




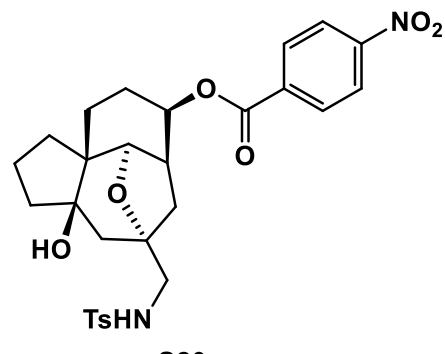

S20a

$\left({ }^{13} \mathrm{C}-\mathrm{NMR}, \mathrm{CDCl}_{3}, 125 \mathrm{MHz}\right.$ )
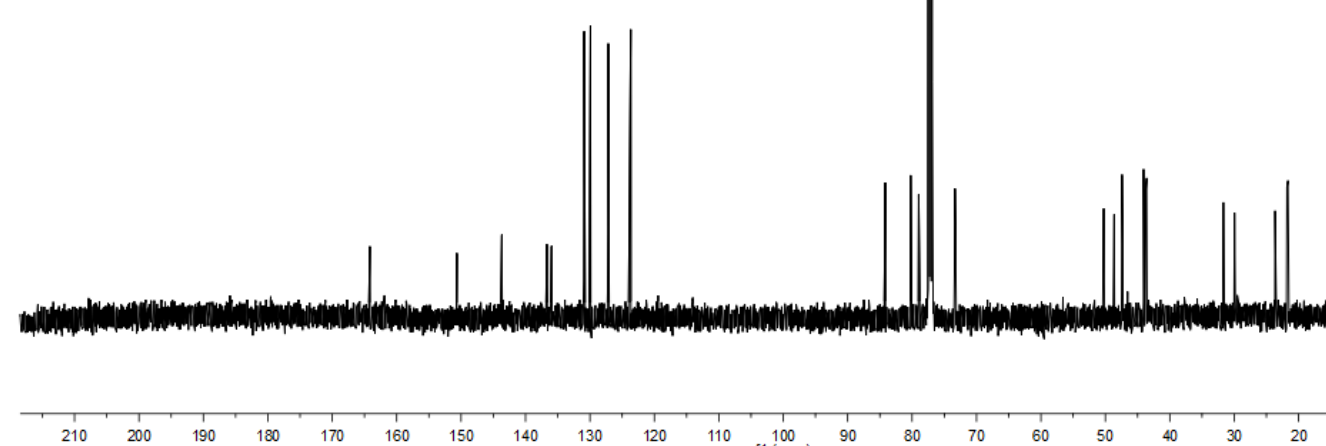

$10 \quad \begin{gathered}100 \\ f 1(0 \mathrm{pm})\end{gathered}$

రิ)

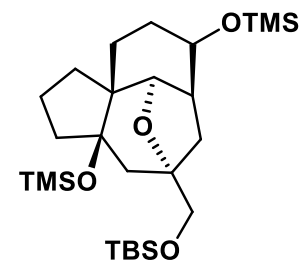

22

( $\left.{ }^{1} \mathrm{H}-\mathrm{NMR}, \mathrm{CDCl}_{3}, 500 \mathrm{MHz}\right)$

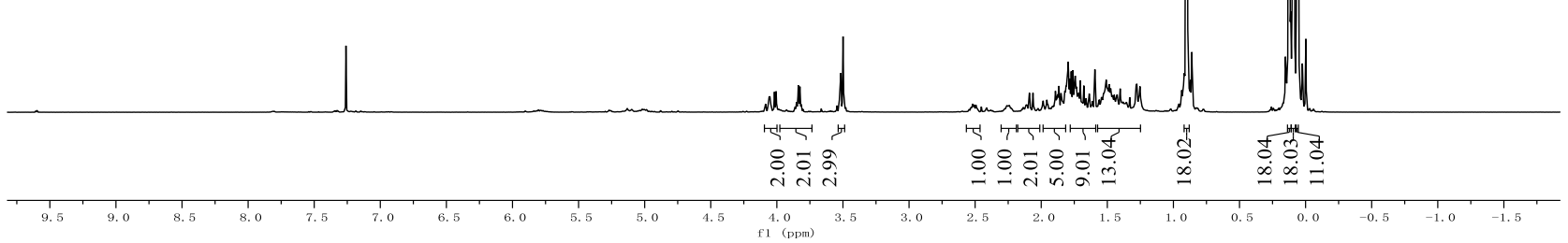




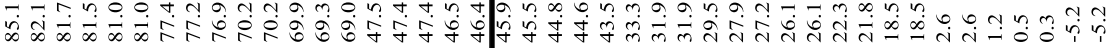

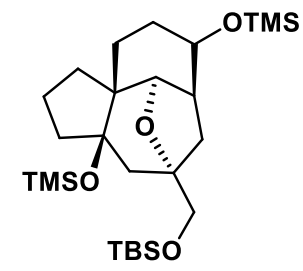

22

( $\left.{ }^{13} \mathrm{C}-\mathrm{NMR}, \mathrm{CDCl}_{3}, 125 \mathrm{MHz}\right)$

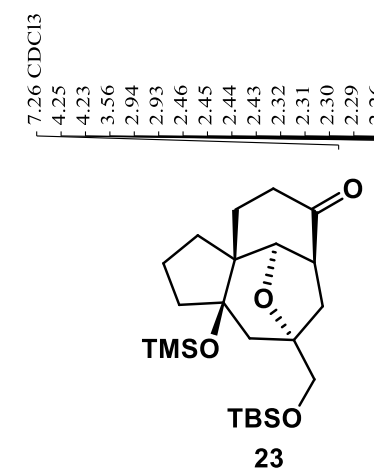

( ${ }^{1} \mathrm{H}-\mathrm{NMR}, \mathrm{CDCl}_{3}, 500 \mathrm{MHz}$ )

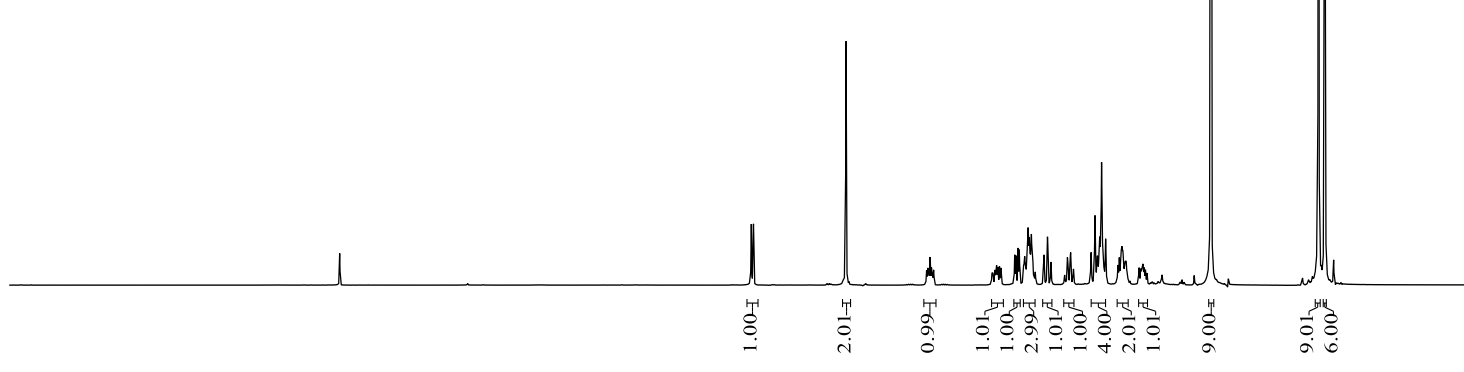


$\underset{\substack{\text { I }\\}}{1}$

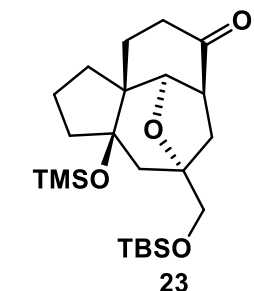

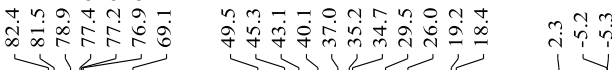

$\left({ }^{13} \mathrm{C}-\mathrm{NMR}, \mathrm{CDCl}_{3}, 125 \mathrm{MHz}\right)$
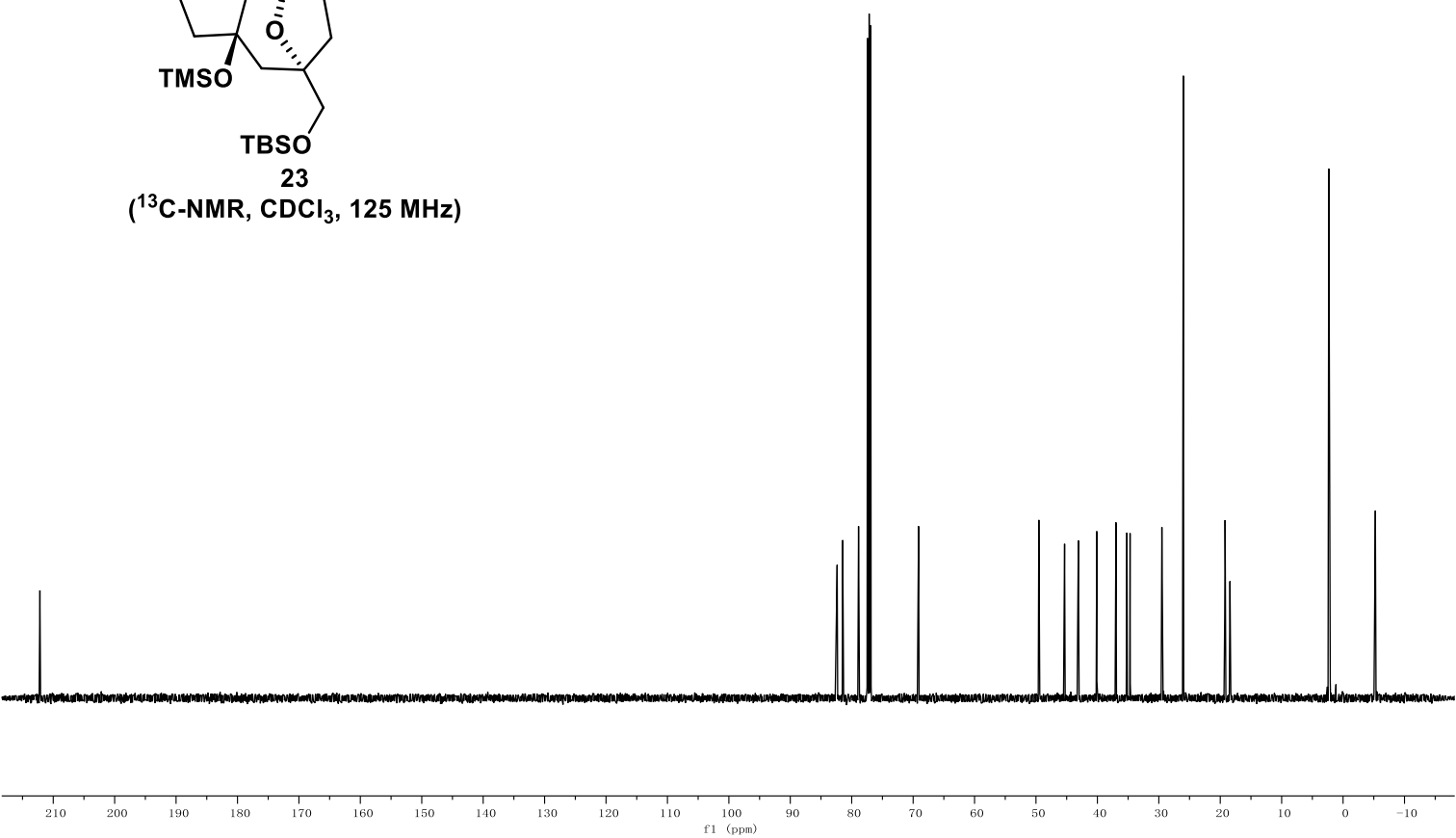

己ֶ)

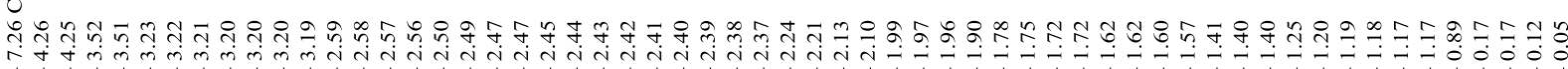

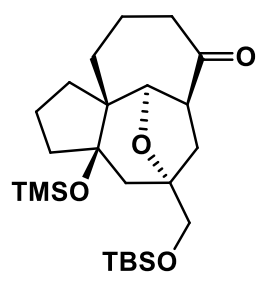

24a (major)

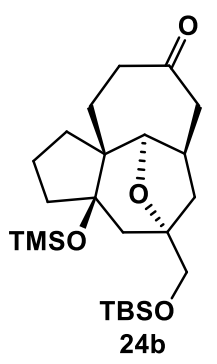

24a: $24 b=6: 1$

('H-NMR, $\mathrm{CDCl}_{3}, 500 \mathrm{MHz}$ )

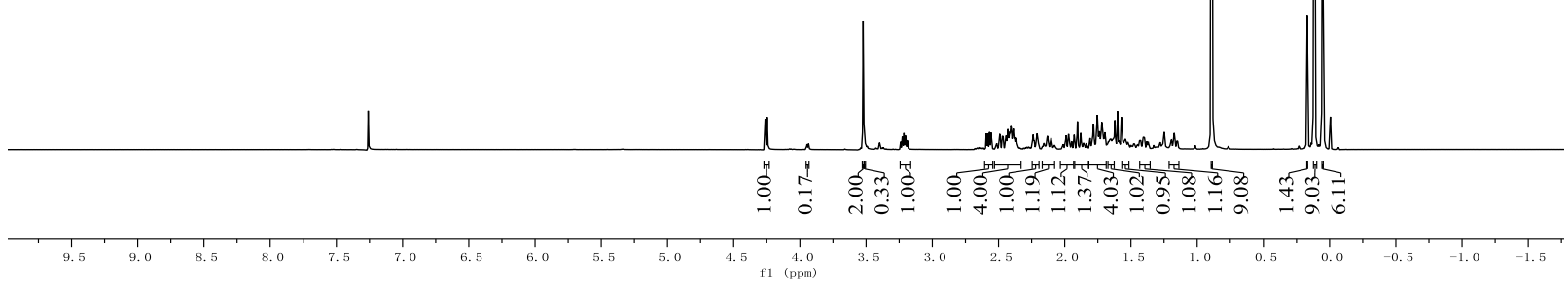



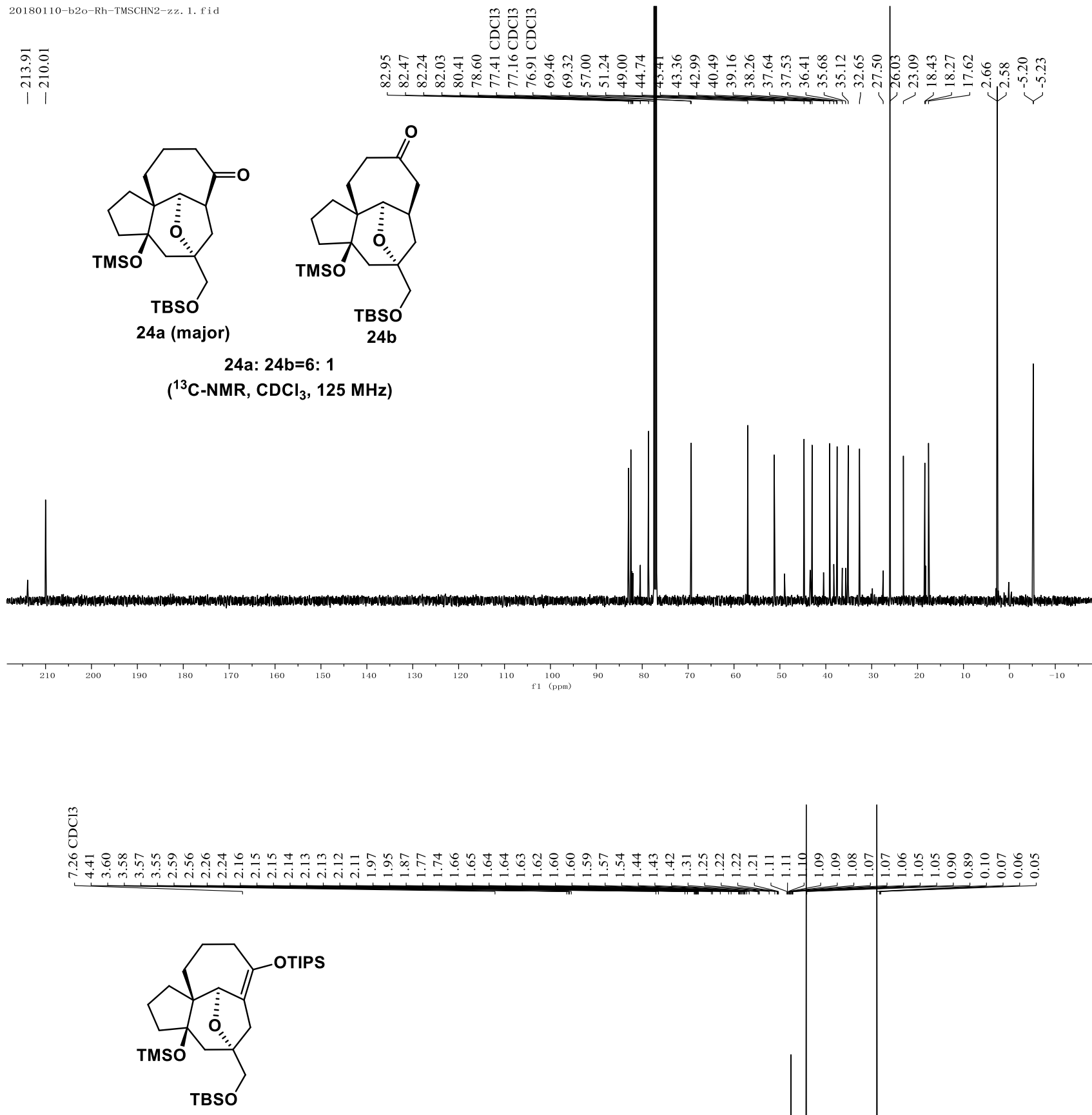

( ${ }^{1} \mathrm{H}-\mathrm{NMR}, \mathrm{CDCl}_{3}, 500 \mathrm{MHz}$ )

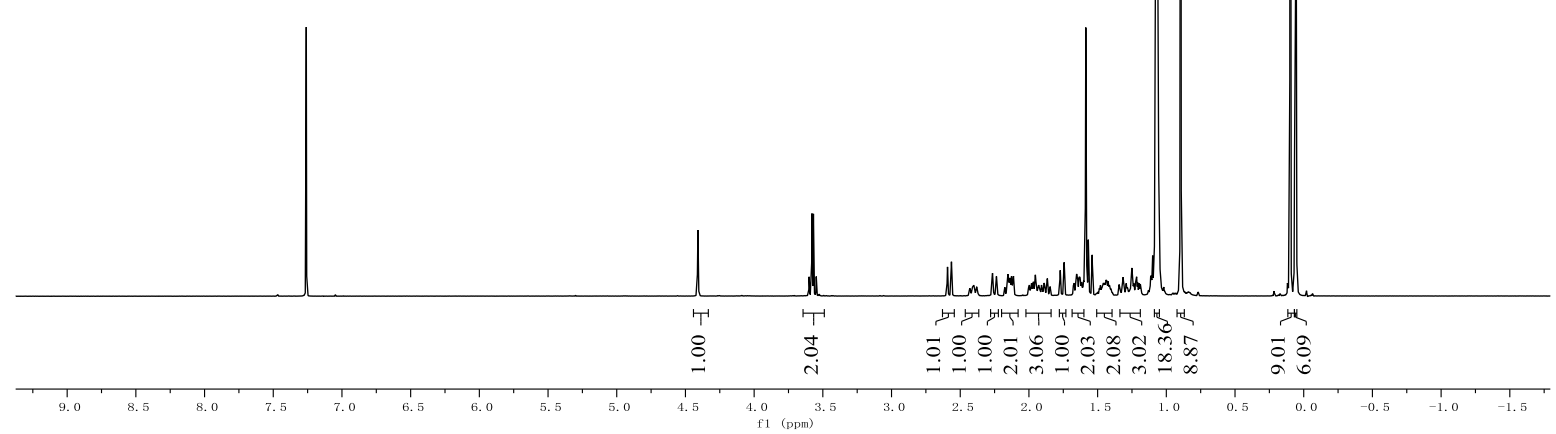



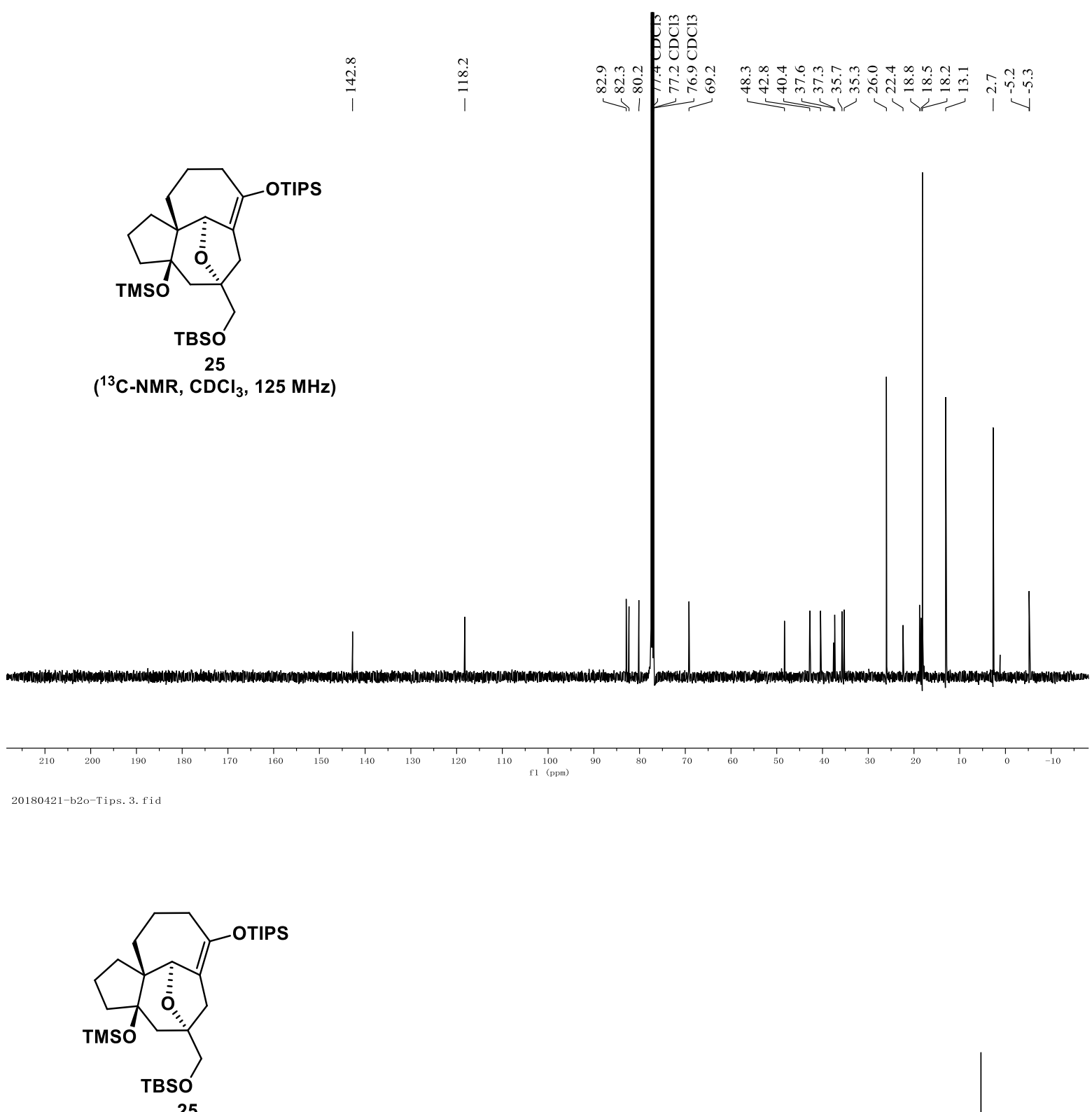

(dept-135, $\mathrm{CDCl}_{3}, 125 \mathrm{MHz}$ )
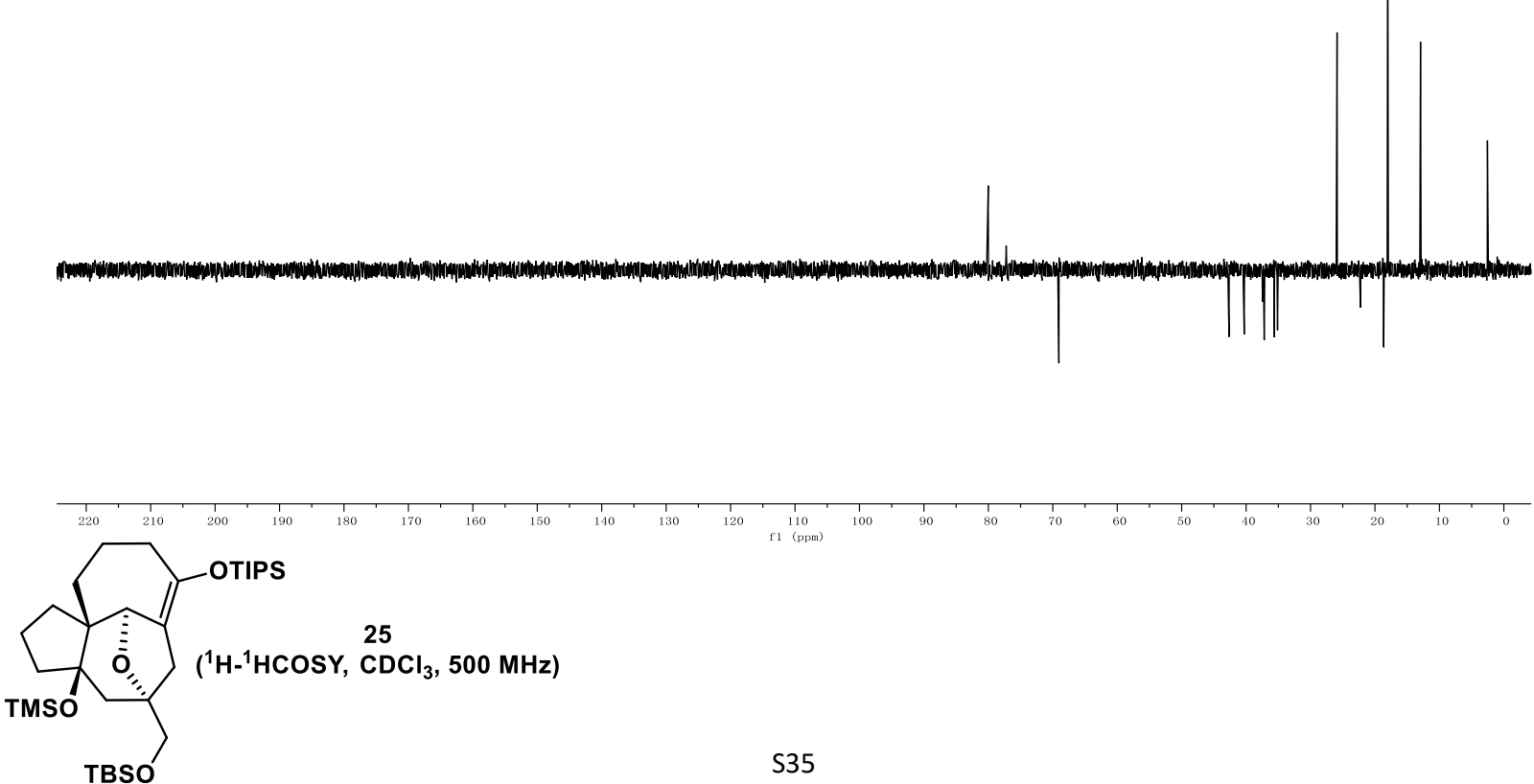

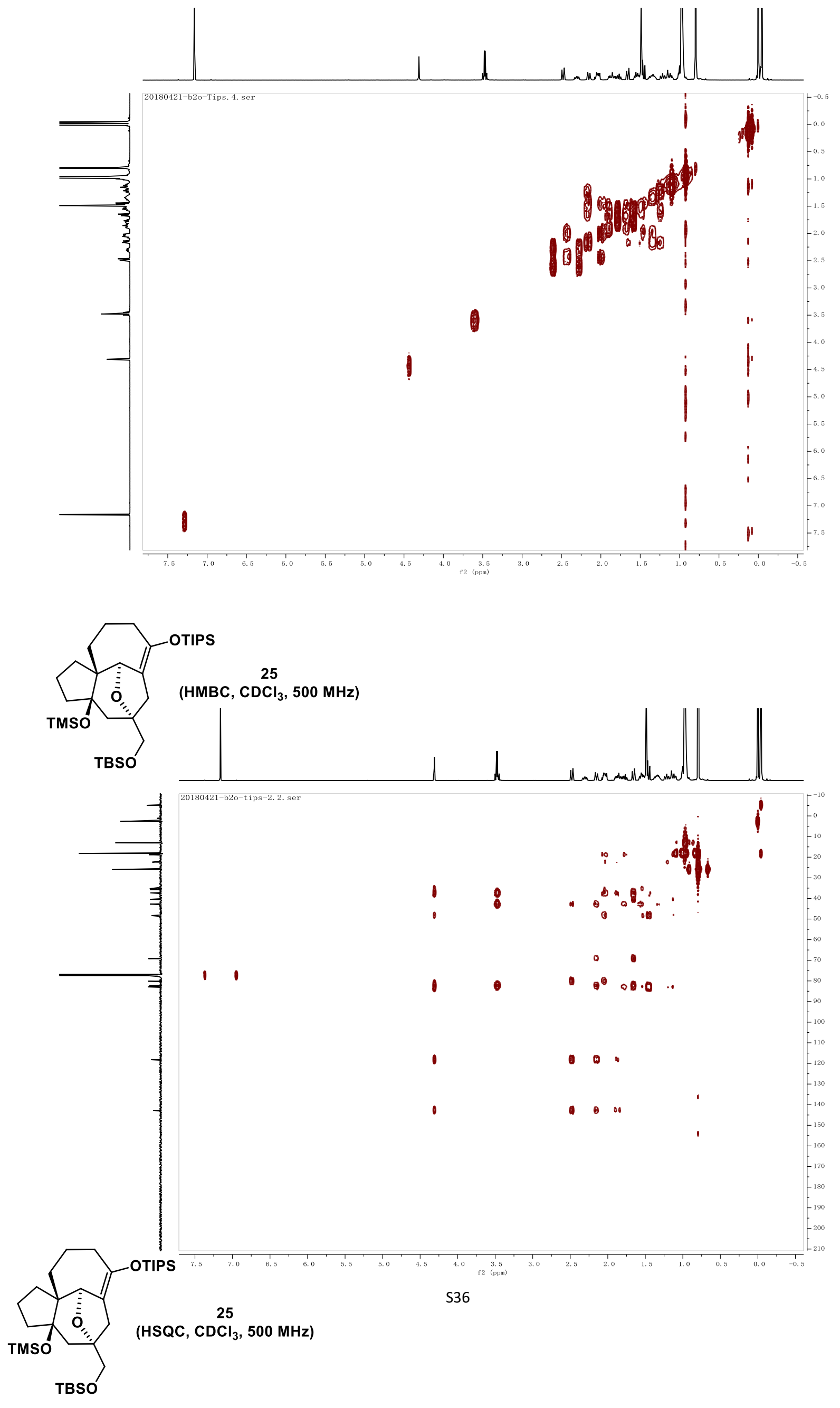


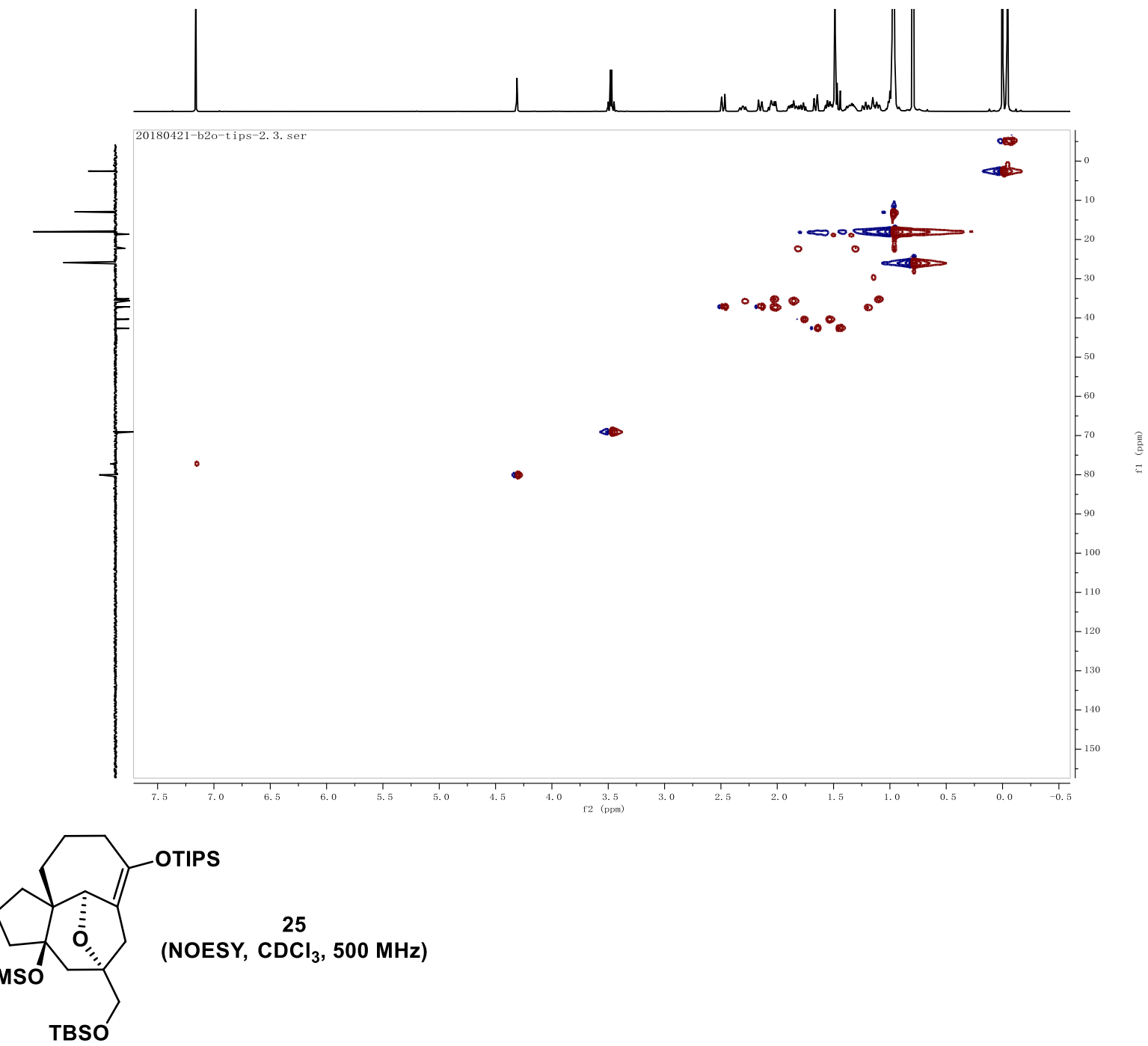

S37 


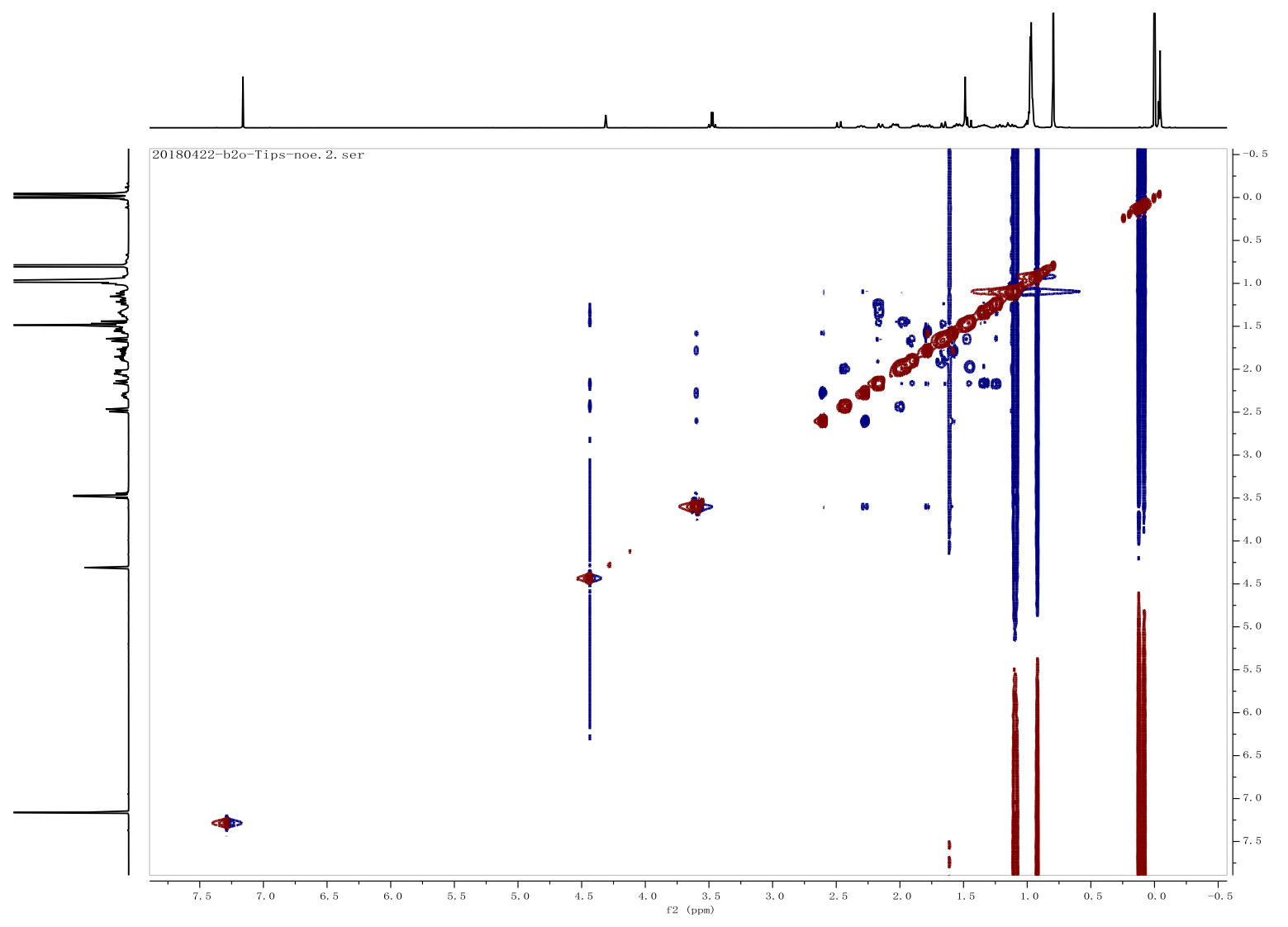

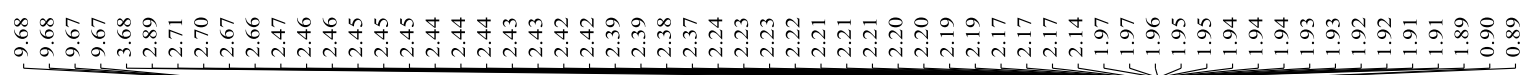

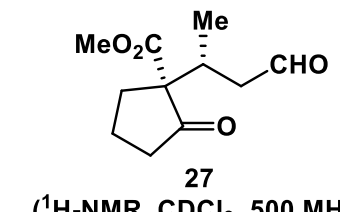

( $\left.{ }^{1} \mathrm{H}-\mathrm{NMR}, \mathrm{CDCl}_{3}, 500 \mathrm{MHz}\right)$

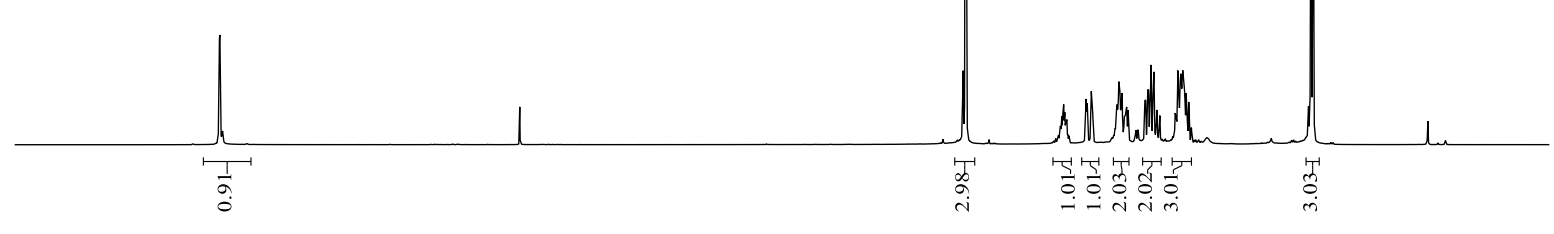




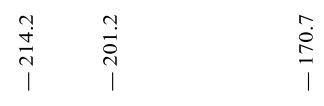

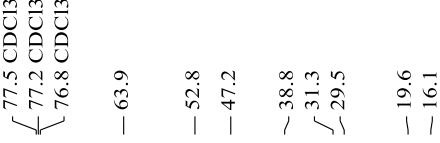

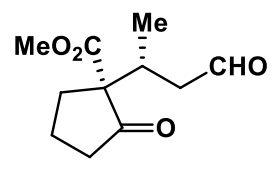

27

$\left({ }^{13} \mathrm{C}-\mathrm{NMR}, \mathrm{CDCl}_{3}, 125 \mathrm{MHz}\right)$
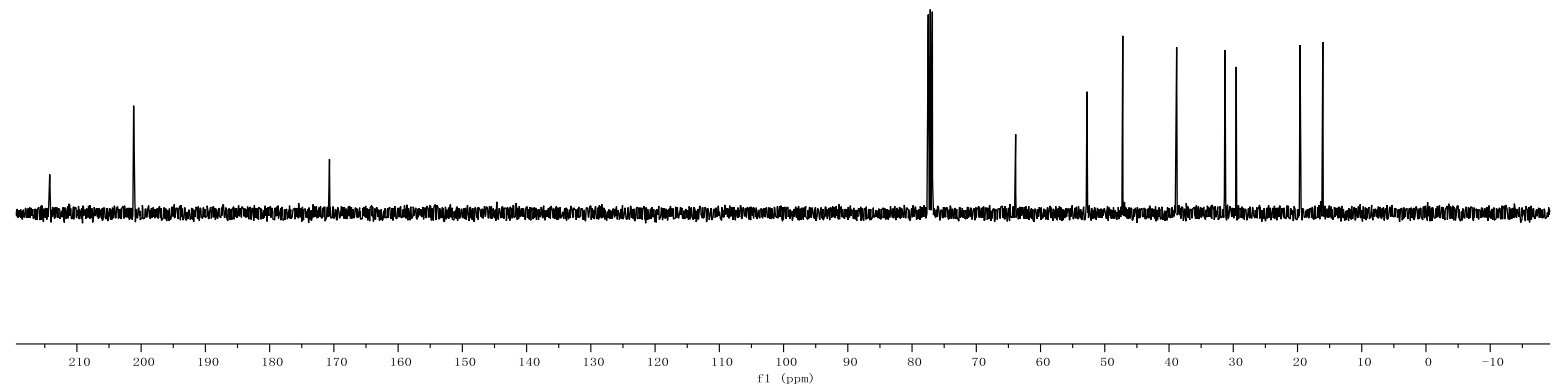

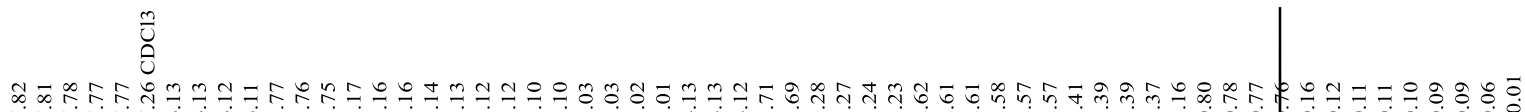

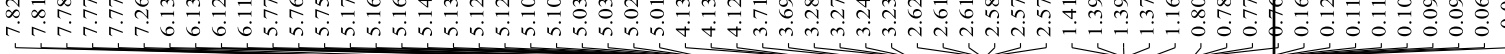

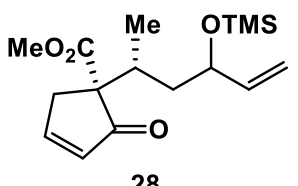

('H-NMR, $\left.\mathrm{CDCl}_{3}, 500 \mathrm{MHz}\right)$

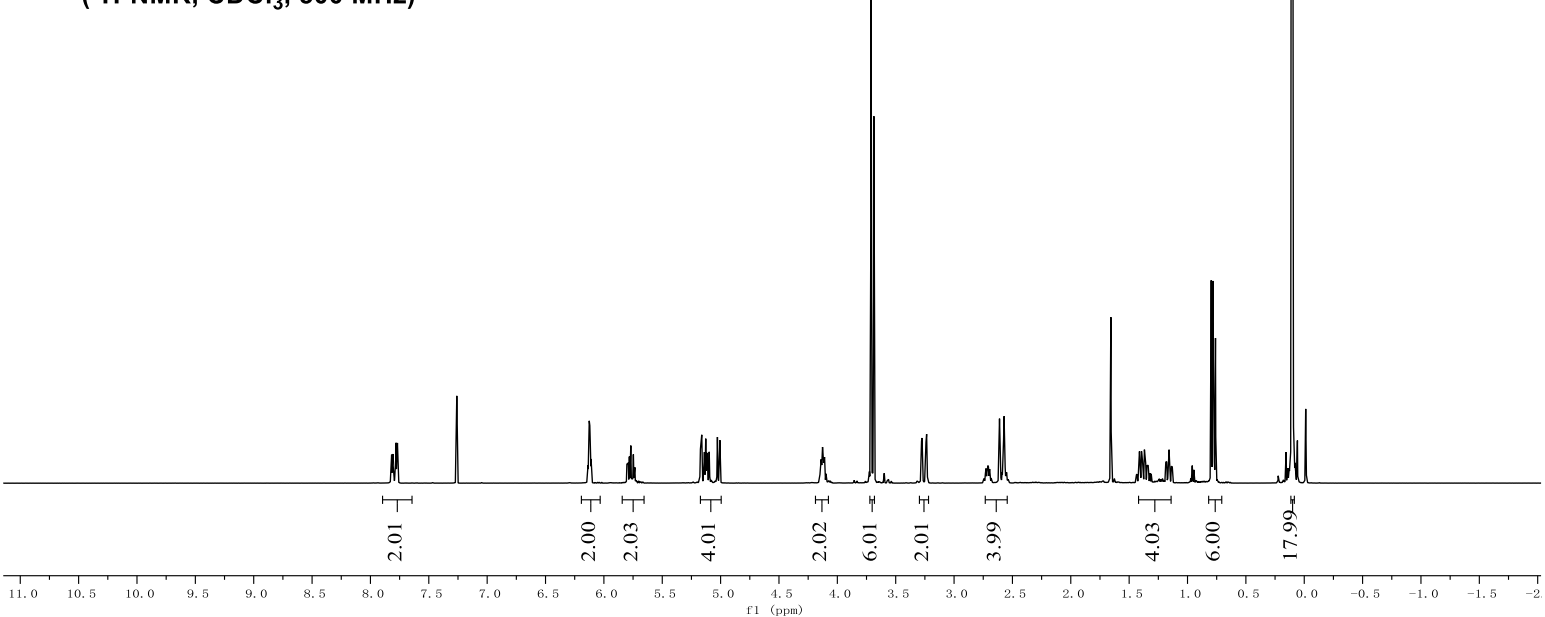



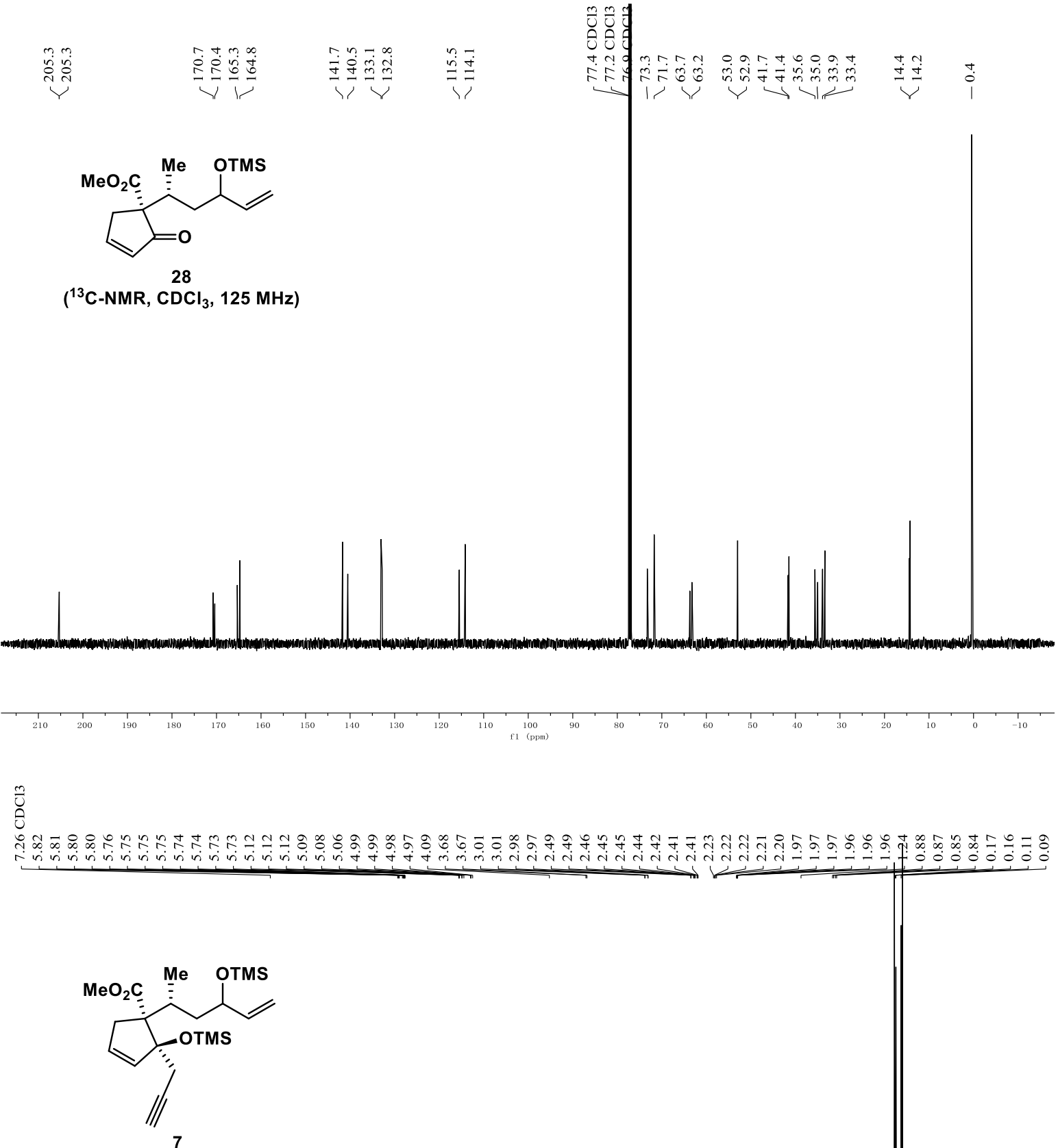

( ${ }^{1} \mathrm{H}-\mathrm{NMR}, \mathrm{CDCl}_{3}, 500 \mathrm{MHz}$ )

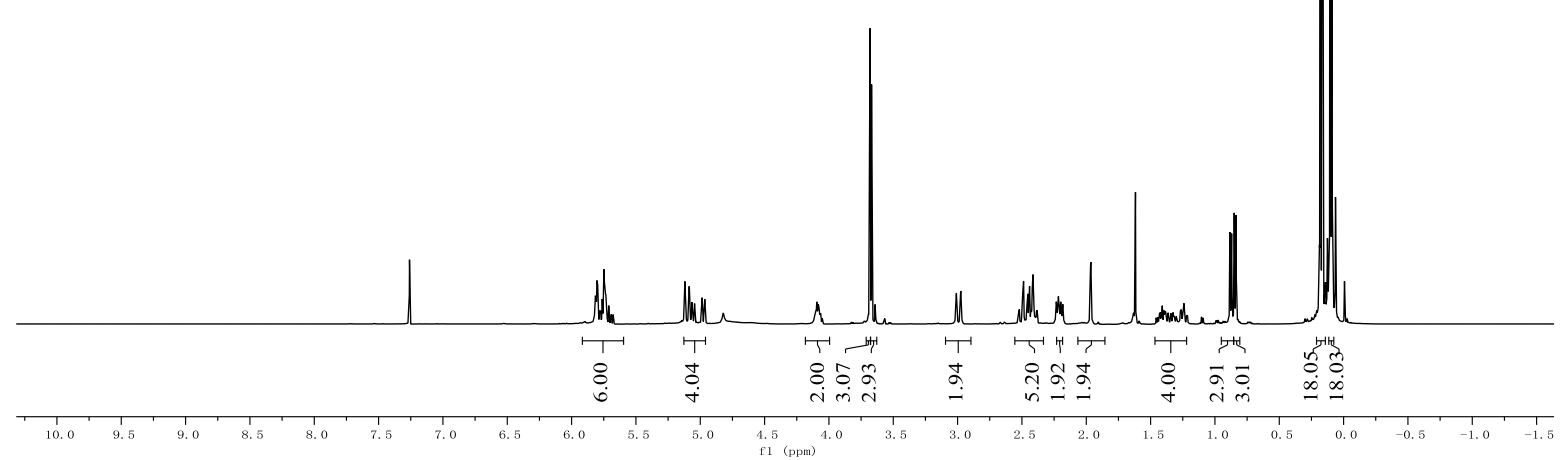




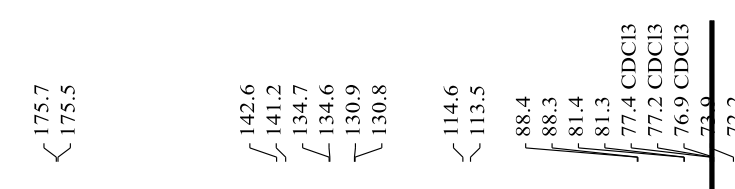

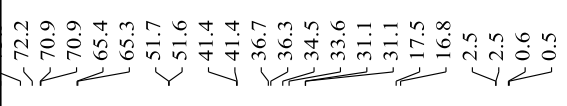

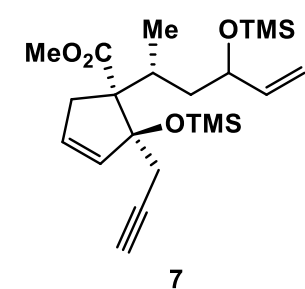

$\left({ }^{13} \mathrm{C}\right.$-NMR, $\left.\mathrm{CDCl}_{3}, 125 \mathrm{MHz}\right)$
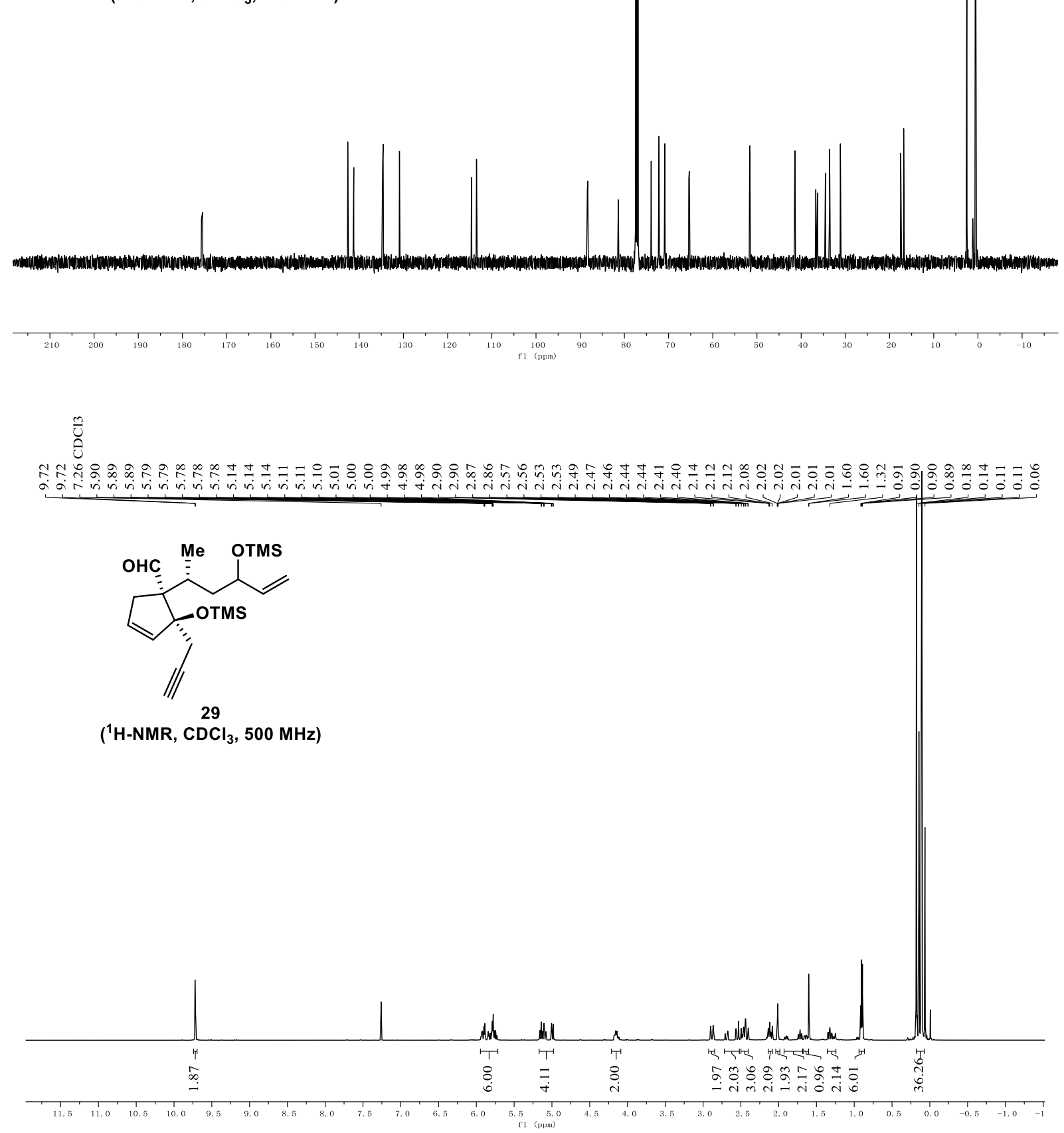

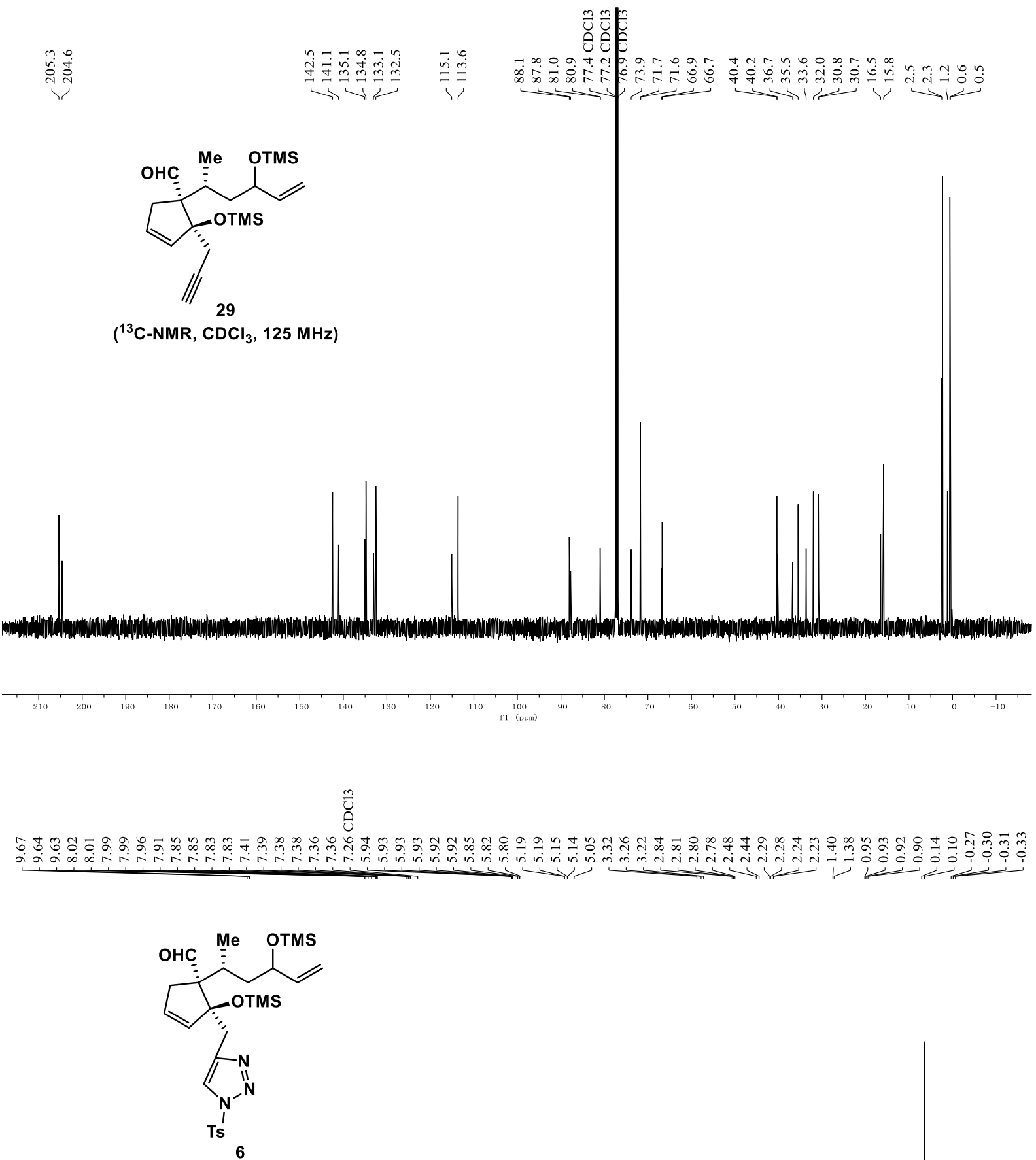

('H-NMR, $\mathrm{CDCl}_{3}, 500 \mathrm{MHz}$ )

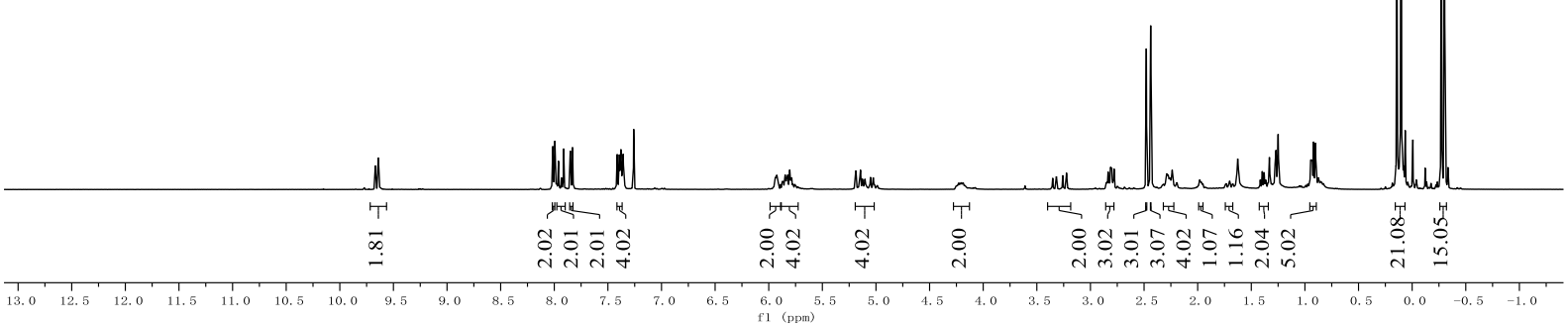


<smiles>C=CC(C[C@H](C)OC)O[C@]1(Cc2cn(C)nn2)C=CCC1(C)CO</smiles>

$\left({ }^{13} \mathrm{C}-\mathrm{NMR}, \mathrm{CDCl}_{3}, 125 \mathrm{MHz}\right)$

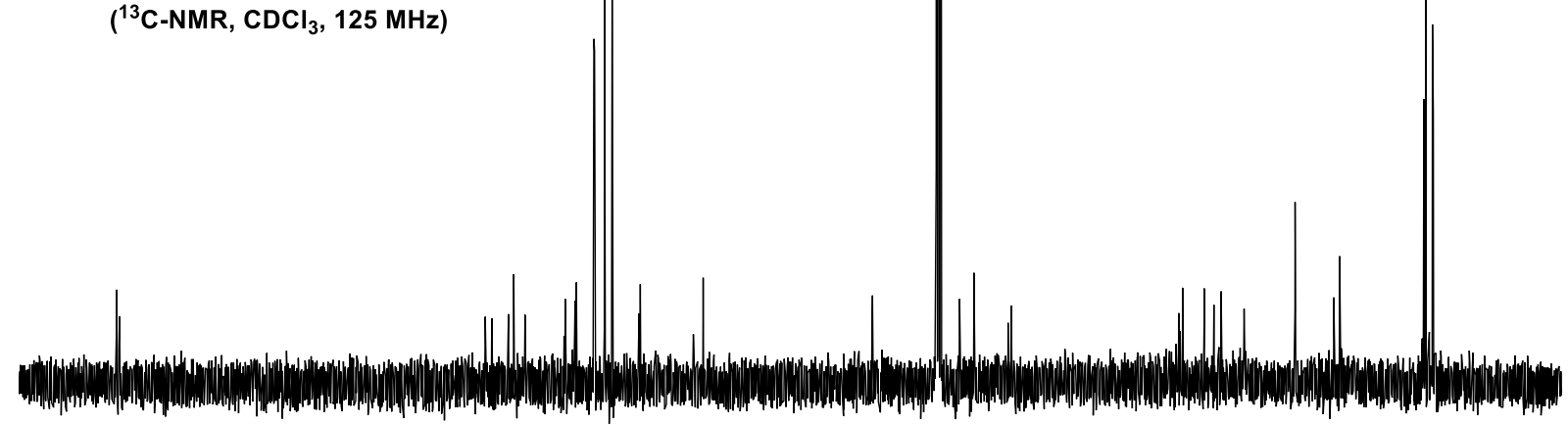

己ِّ

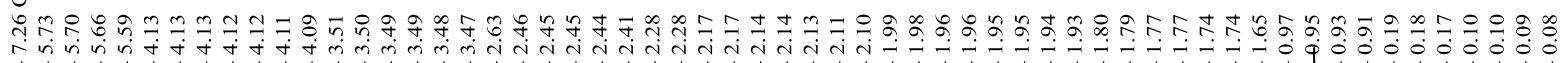
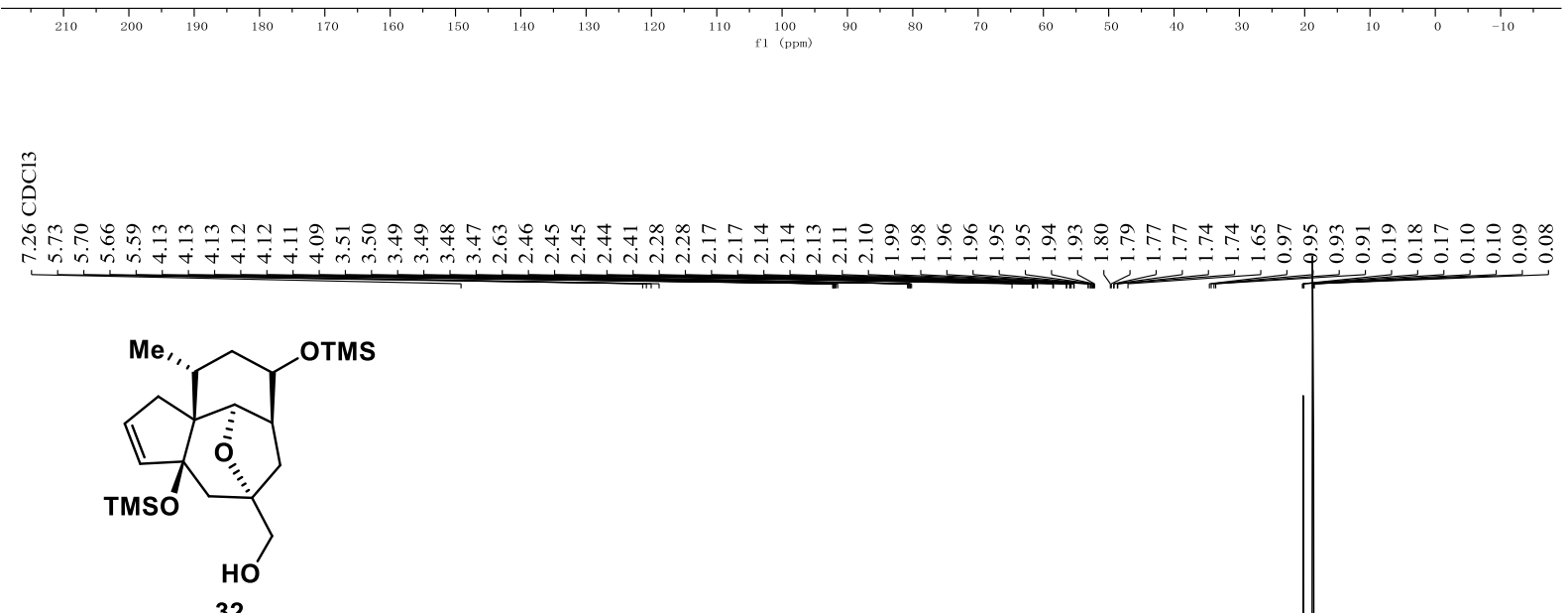

( $\left.{ }^{1} \mathrm{H}-\mathrm{NMR}, \mathrm{CDCl}_{3}, 500 \mathrm{MHz}\right)$

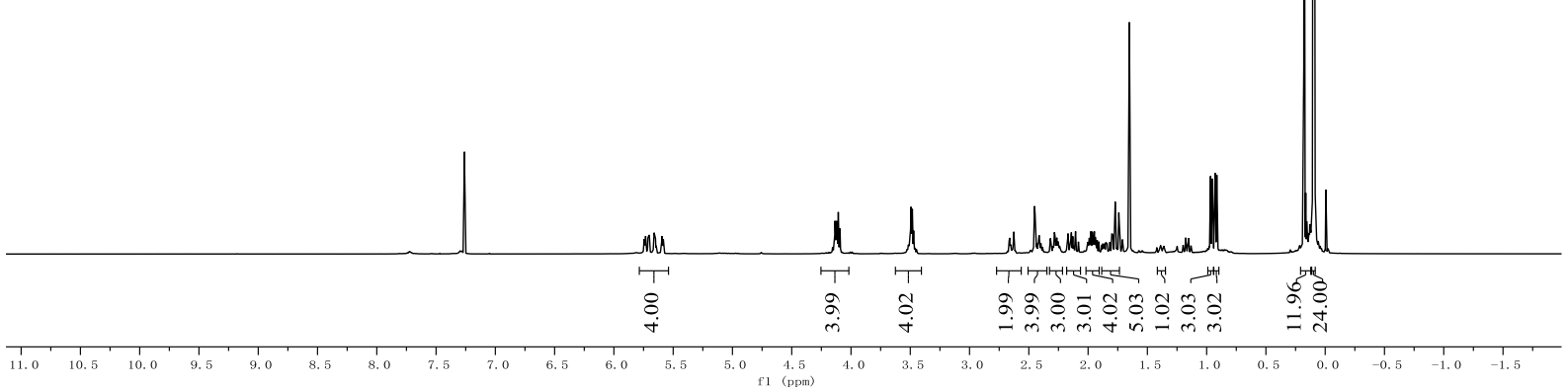



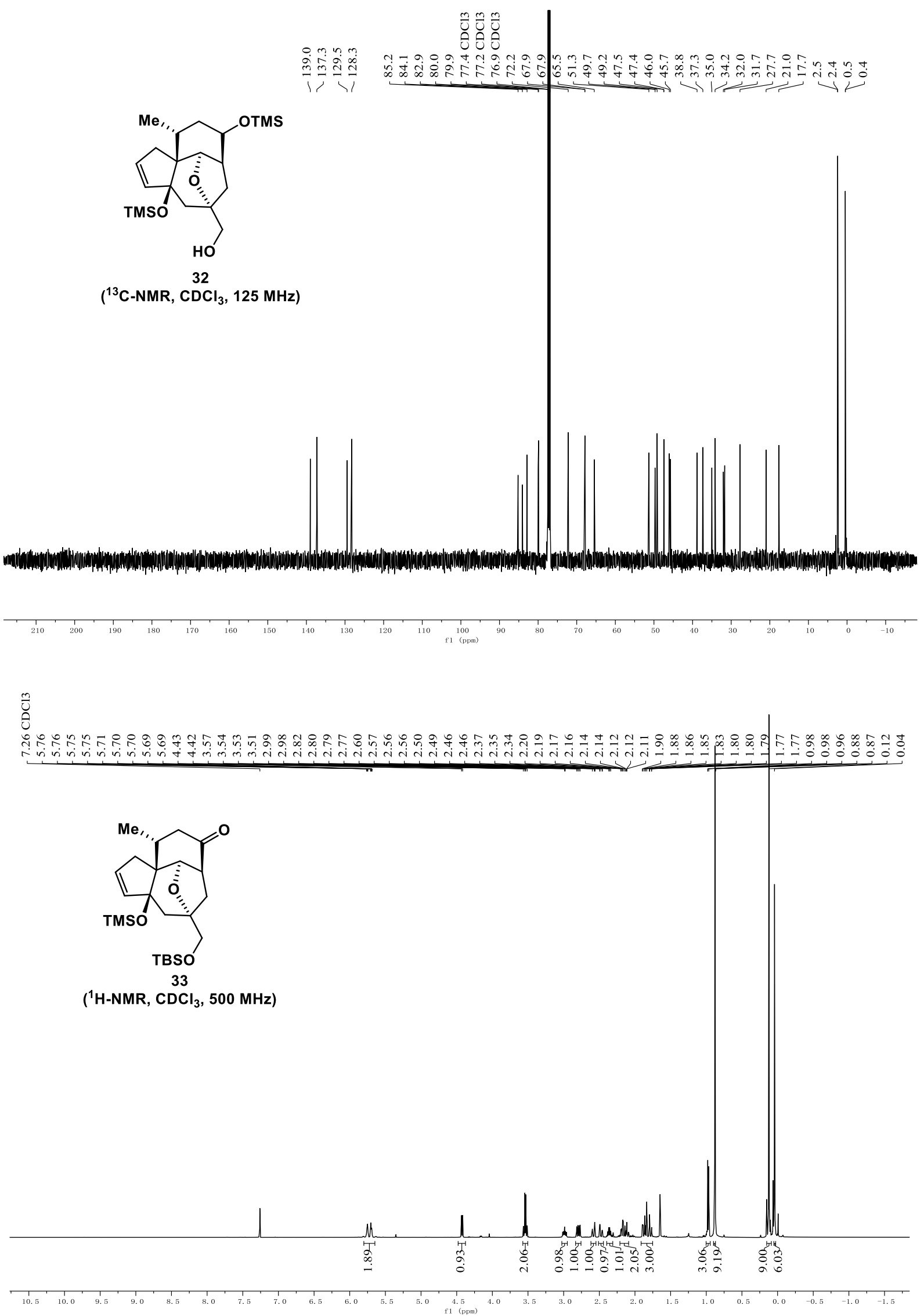

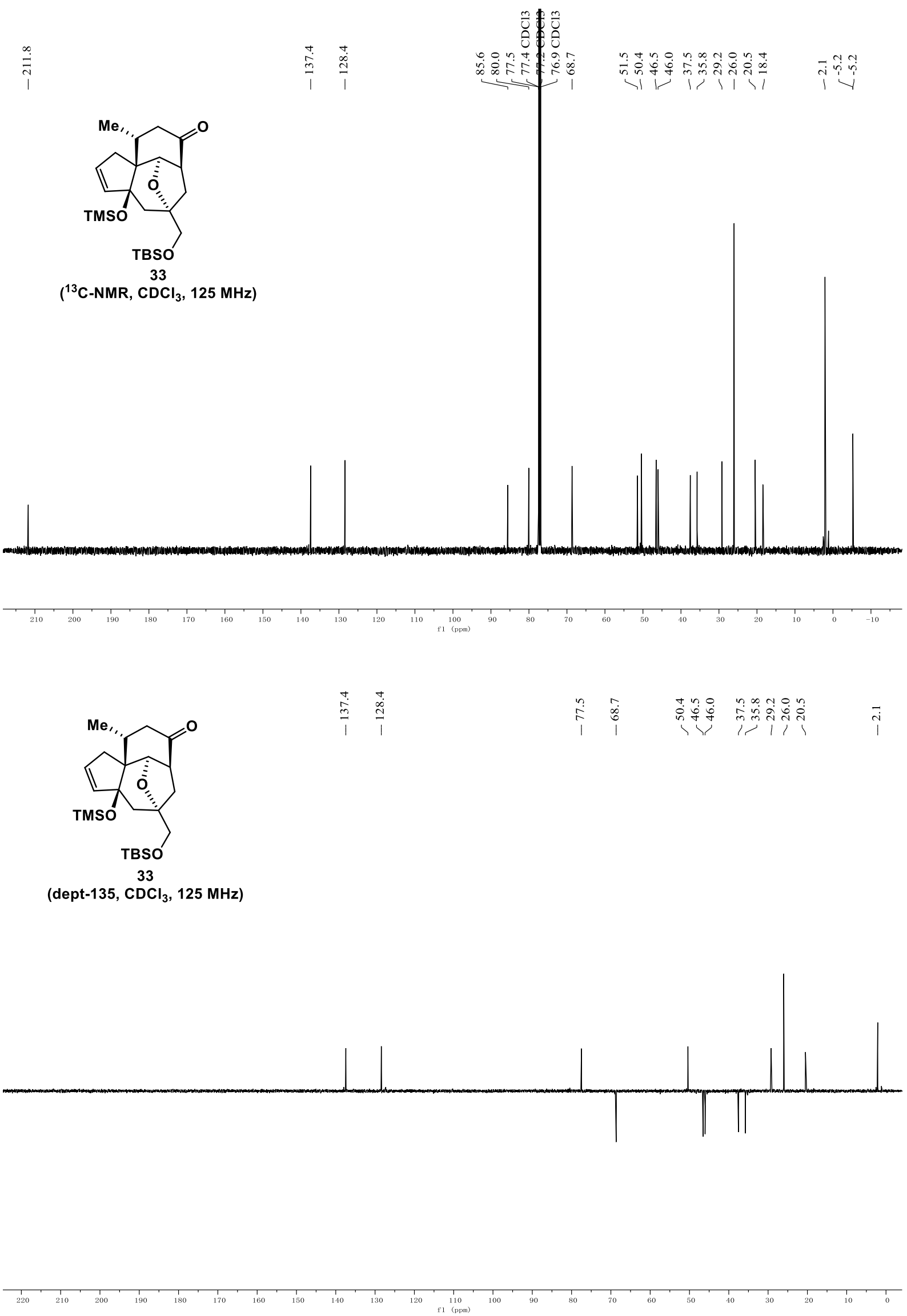

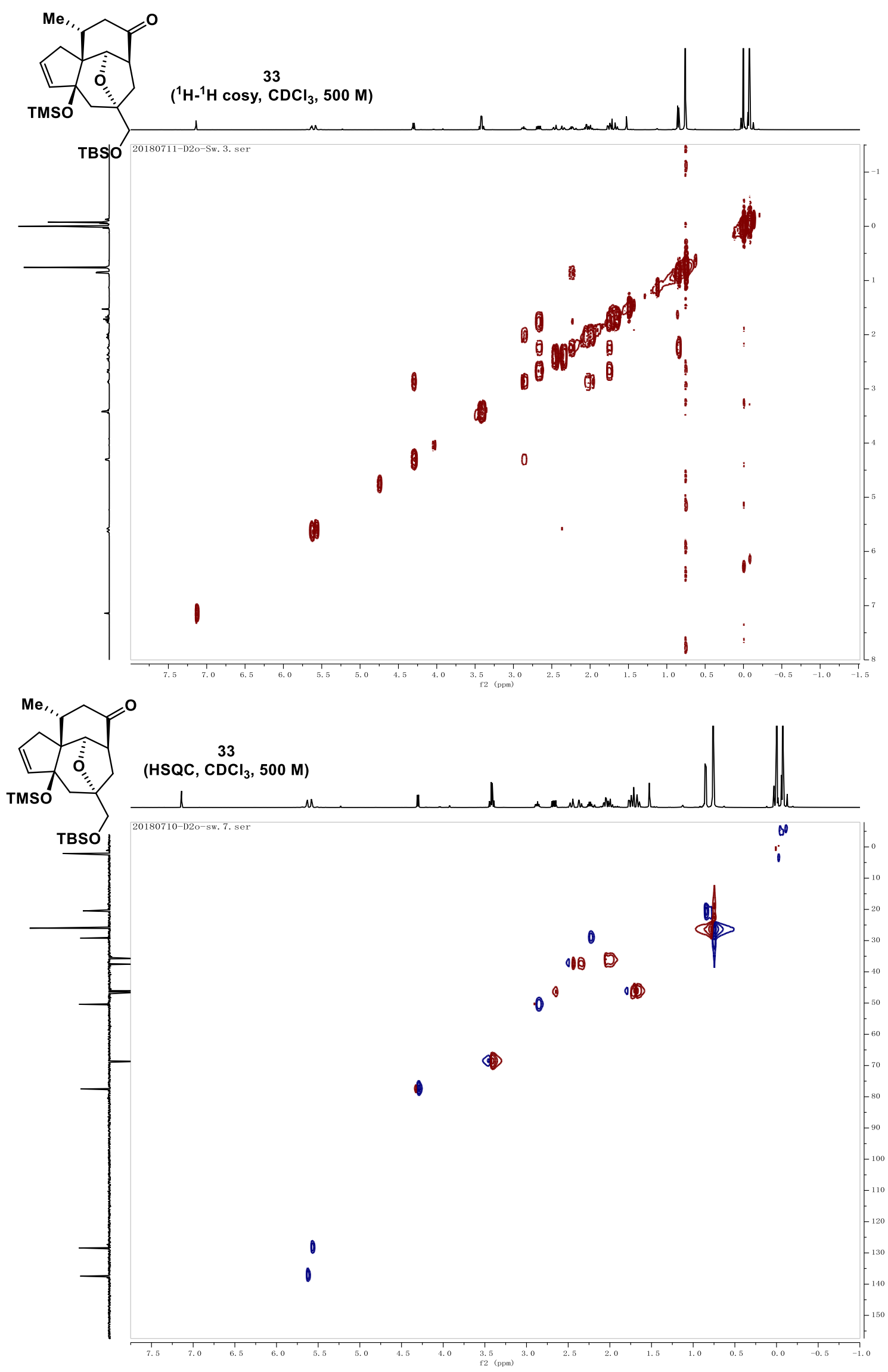

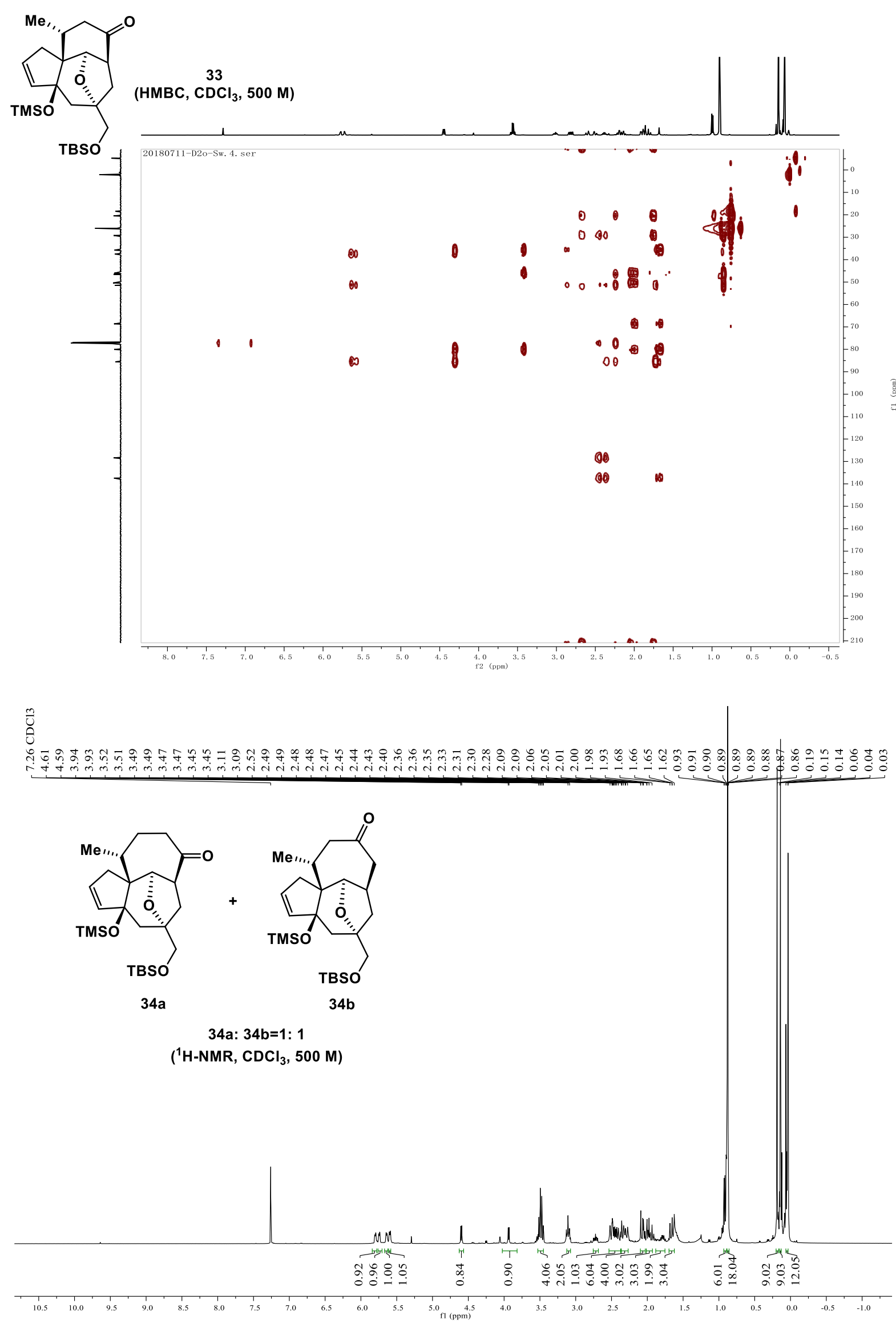

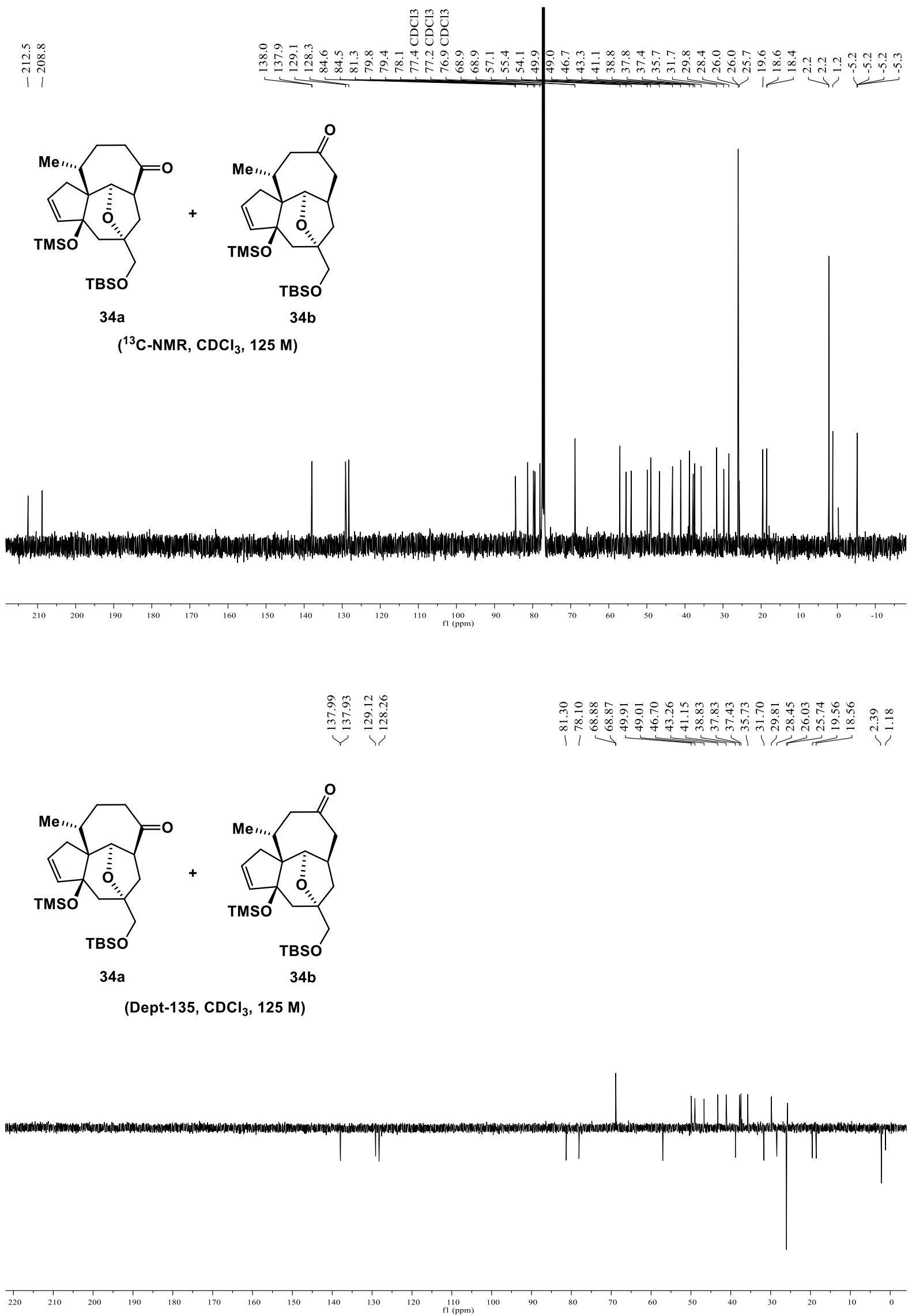


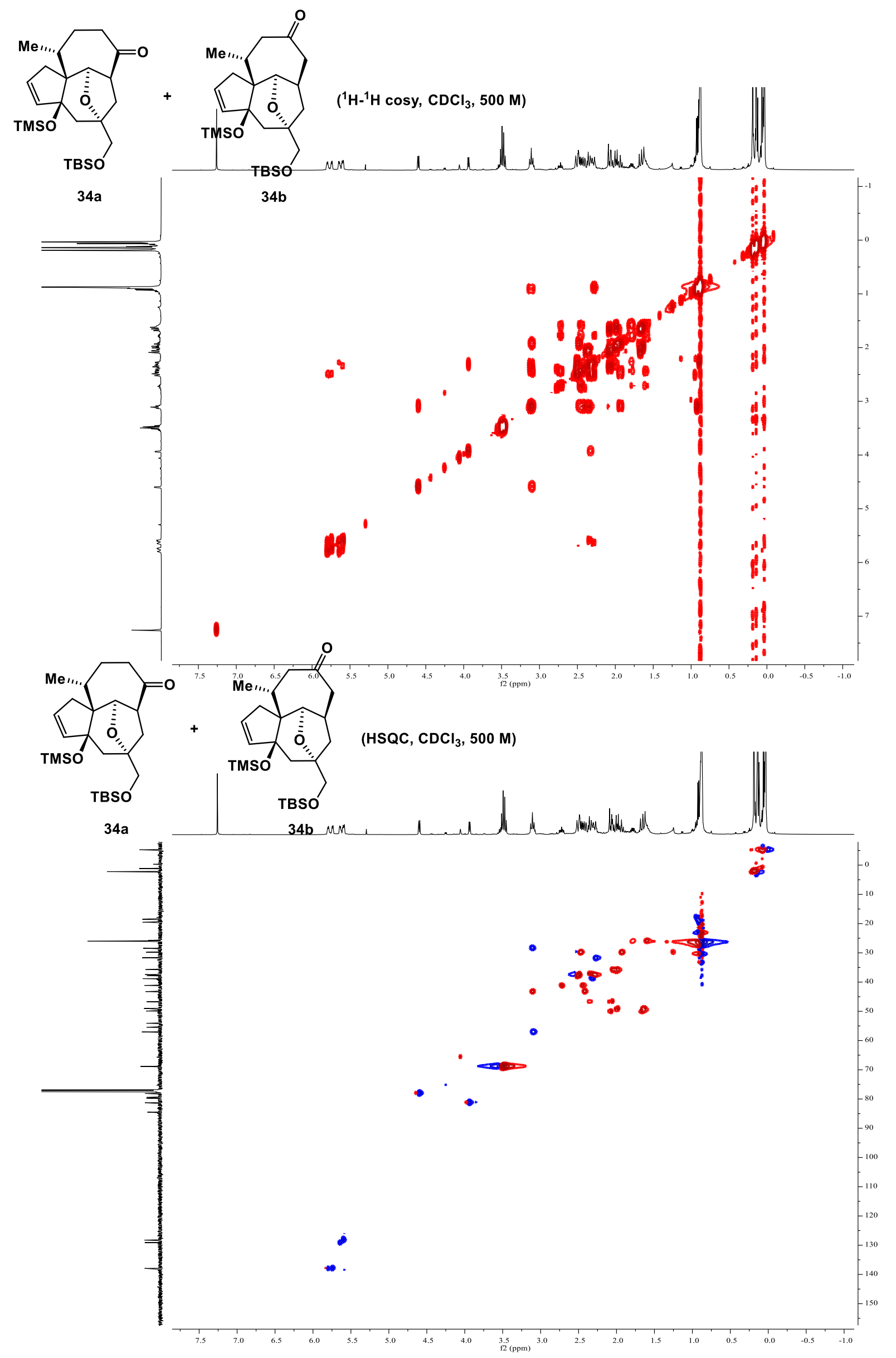




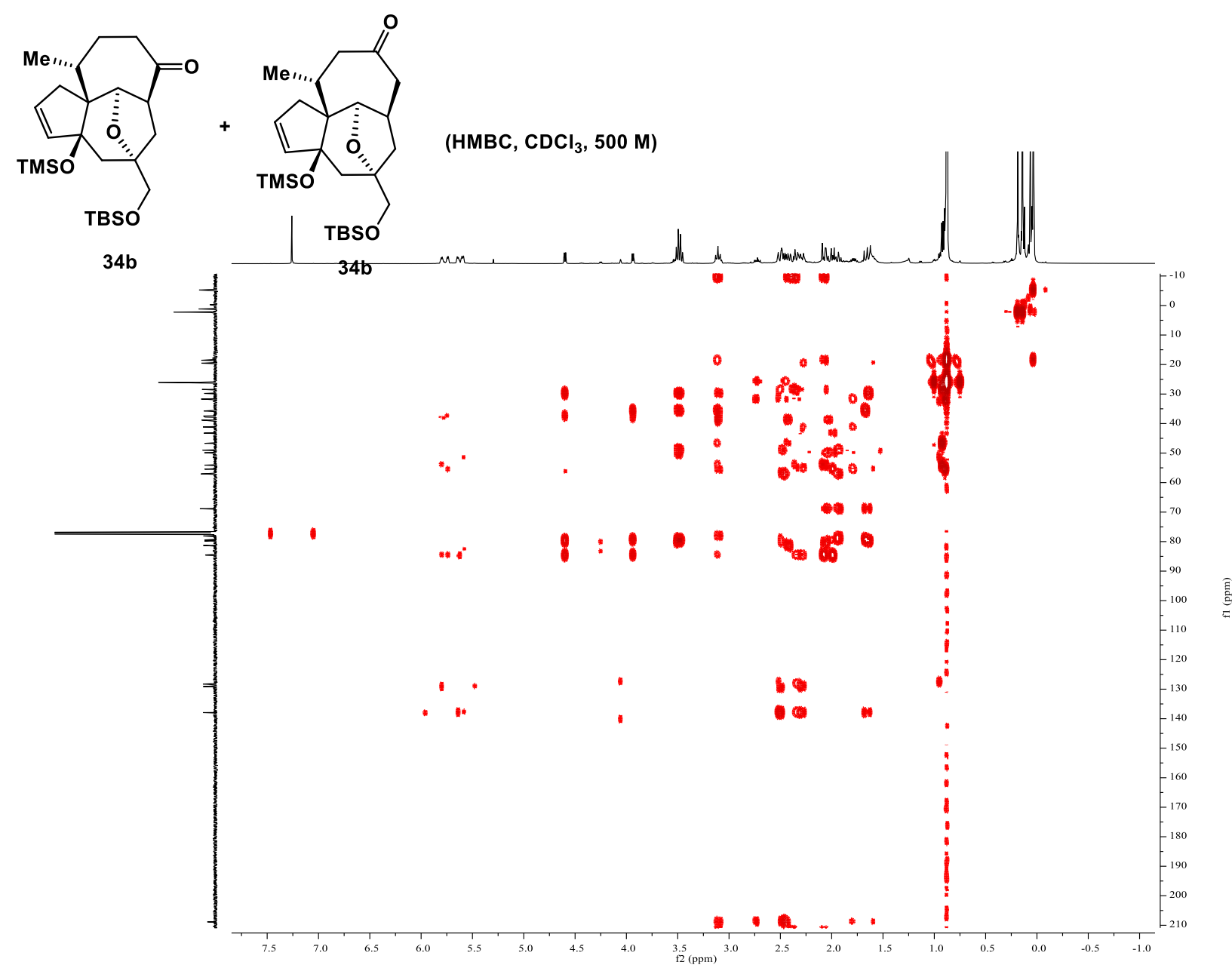

